\title{
Overview of 2003 Pesticide Sales in Alberta
}


ISBN: 0-978-0-7785-7364-7 (Printed edition)

0-978-0-7785-7365-4 (On-line edition)

Website Address: http://environment.gov.ab.ca/info/home.asp

\section{ACKNOWLEDGEMENTS}

The assistance and input of the following people was greatly appreciated during the preparation and compilation of this report:

Janet McLean, Anne-Marie Anderson, Jamie Legarie, Betty Hope, Steve Clare, Michael Seneka and Ted Bolseng of Alberta Environment; Jamie Wuite, and Murray Hartman of Alberta Agriculture and Food.

More information regarding the "Overview of 2003 Pesticide Sales in Alberta" may be obtained by contacting:

\section{Environmental Assurance \\ Alberta Environment \\ $10^{\text {th }}$ Floor 9820 - 106 Street \\ Edmonton, Alberta T5K 2J6 \\ Phone: (780) 427-9911}

Additional copies of this report may be obtained by contacting:

Information Centre

Alberta Environment

Main Floor, Oxbridge Place

9820 - 106th Street

Edmonton, Alberta T5K 2J6

Phone: (780) 422-2079

Fax: (780) 427-4407

Email: env.infocent@gov.ab.ca 


\section{Overview of 2003 Pesticide Sales in Alberta}




\section{EXECUTIVE SUMMARY}

Alberta Environment undertook the collection, consolidation and analysis of pesticide sales data from pesticide vendors in Alberta for the 2003 calendar year. The objective was to document the volume and types of pesticides sold in Alberta, and to prepare a general overview of the sales data in relation to sectors of use, types of use, individual active ingredients, chemical groupings, as well as geographic breakdowns by river basin and municipality. This project is an ongoing survey conducted every five years, with previous reports being done for 1993 and 1998. The 1998 report followed the chemical grouping format used by Quebec in their reporting on pesticide sales in their province, and with the proposed National Pesticide Sales Database, however the 2003 report also includes individual active ingredient sales information.

Pesticide sales data was requested from registered pesticide vendors and wholesalers in Alberta in early 2004, under the authority of the Environmental Protection and Enhancement Act and supporting regulations. Approximately $92 \%$ compliance with the sales data request was obtained. Sales data received was digitized or reformatted to a common database format. Six additional datasets were constructed to assist with sorting and categorizing the sales records by chemical or geographic groups. The datasets were brought into Microsoft Access, where they were linked and various queries were performed.

In 2003, a total of $9264487.7 \mathrm{~kg}$ of pesticide active ingredient (ai) was sold in, or shipped into, Alberta. Pesticides sold into the Agriculture sector accounted for $96.2 \%$ of all pesticides sold, with the Commercial/Industrial sector accounting for $3.1 \%$ of sales, and the Domestic sector accounting for $0.6 \%$ of sales. The types of pesticides sold were predominantly herbicides, at $77.3 \%$. Adjuvants and surfactants made up the-next largest category at $14.6 \%$. Insecticides made up $4.7 \%$ of sales, while fungicides made up $3.4 \%$ of sales.

Of the chemical groups, the Phosphonic Acids, Phosphinic Acids group was the largest at $38.1 \%$ of overall sales. Sales in this group were made up primarily of glyphosate. However, in the Domestic sector, the Phenoxy Acids group dominated with $35.2 \%$ of pesticide active ingredient (mainly 2,4-D) sold.

Looking at geographic distribution of sales by outlet location related to major river drainage, sales in the Oldman River basin were highest overall at $21.4 \%$ of the total, followed by sales within the Red Deer River basin at $17.6 \%$, the North Saskatchewan River basin at $15.0 \%$, and the Battle River basin at $14.6 \%$.

Pesticide sales were also sorted by natural regions. The Grassland Natural Region constituted over $46 \%$ of all pesticide sales, mainly in the Dry Mixedgrass and Mixedgrass sub regions. The Parkland Natural Region contained almost $39 \%$ of provincial pesticide sales, mainly in the Central Parkland sub-region. The 
majority of the remainder of pesticide sales was in the Dry Mixedwood sub-region of the Boreal Natural Region.

Geo-administrative regions were also summarized, for use in program planning. The municipalities with the highest sales were the County of Lethbridge and the MD of Taber, at over 500,000 kg of active ingredient. Based upon their cropped acreage, total pesticide use intensities of over $2.5 \mathrm{~kg}$ ai/ha were estimated for these municipalities.

This compares to an overall provincial estimated agricultural pesticide use intensity (based upon cultivated land acreage) of $0.78 \mathrm{~kg}$ ai/ha, comparable to the $0.79 \mathrm{~kg}$ ai/ha agricultural pesticide use intensity calculated for 1998. Other municipalities with over $300000 \mathrm{~kg}$ ai of agricultural pesticide sales were the Counties of Forty Mile and Vermilion River, as well as Kneehill County and Vulcan County. Estimated pesticide use intensities for these municipalities ranged from 0.97 to $1.50 \mathrm{~kg}$ ai $/ \mathrm{ha}$. These municipalities may also serve as regional supply centres, so the use intensity estimates may be an overestimation.

The overview of pesticide sales data for Alberta has provided Alberta Environment and other agencies with the background data to enable comparisons to other regions, and to assist in ensuring that Alberta Environment has the appropriate regulatory framework in place for pesticides. The data will also be useful in identifying monitoring priorities for ongoing and upcoming monitoring programs. 


\section{TABLE OF CONTENTS}

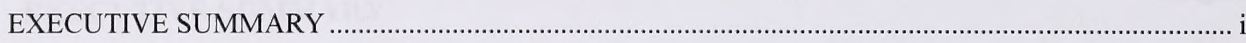

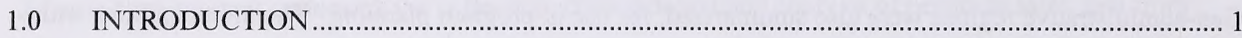

2.0 METHODS

$2.1 \quad$ Sales Data

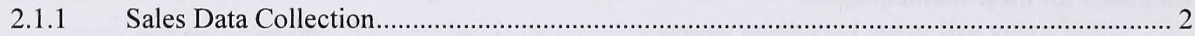

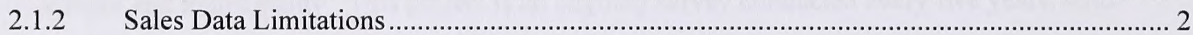

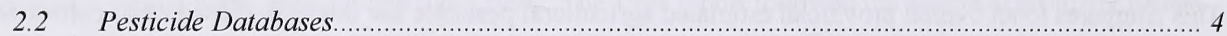

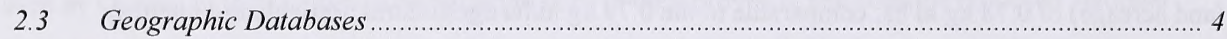

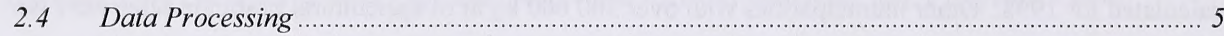

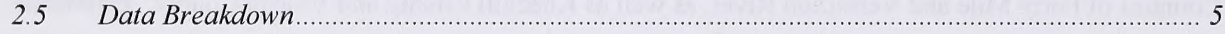

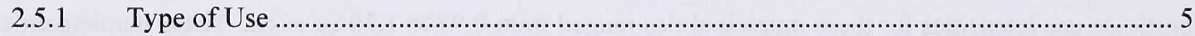

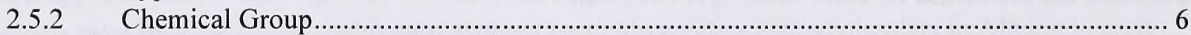

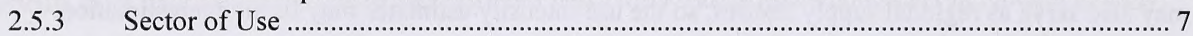

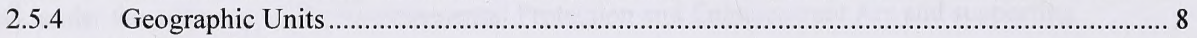

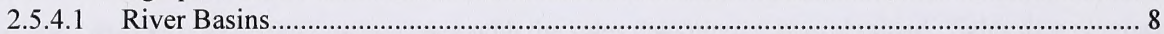

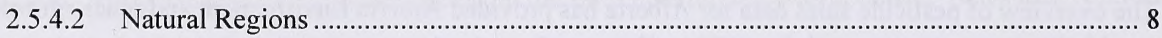

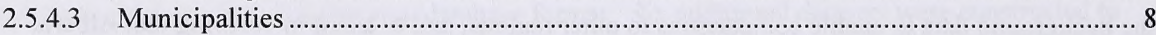

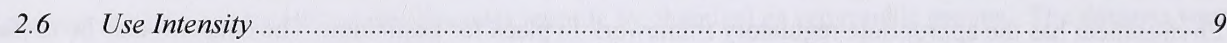

3.0 RESULTS

3.1 Type of Use

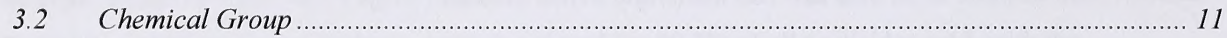

3.3 Sector of Use.

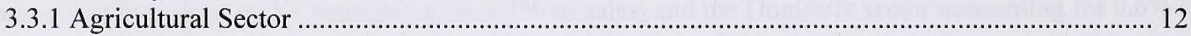

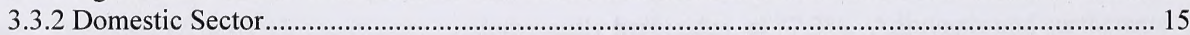

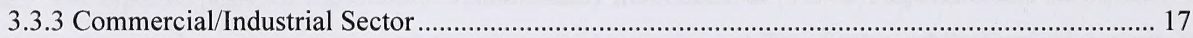

3.3.4 Other Sectors ................................................................................................... 18

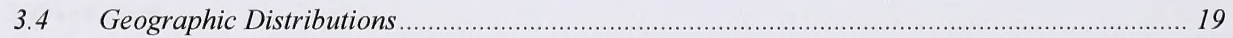

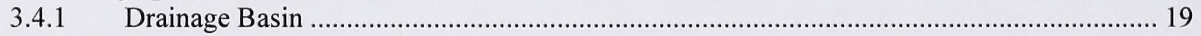

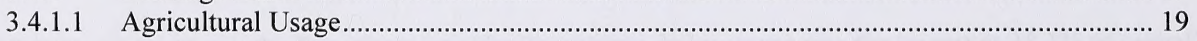

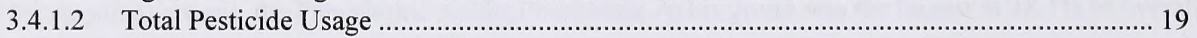

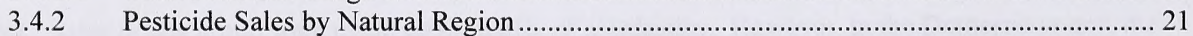

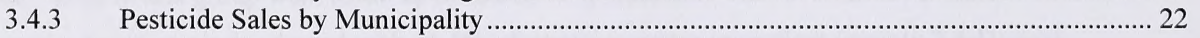

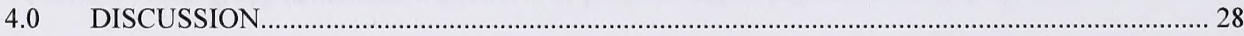

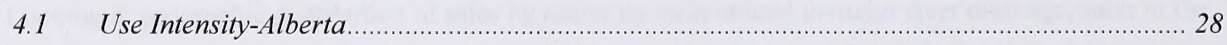

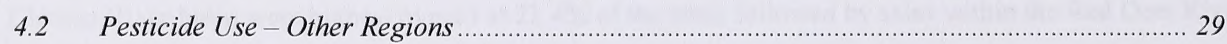

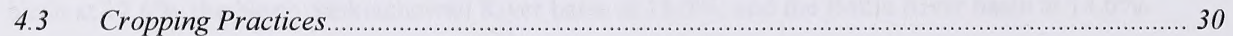

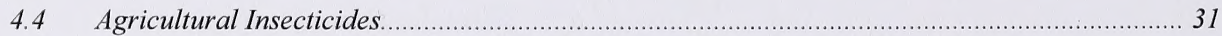

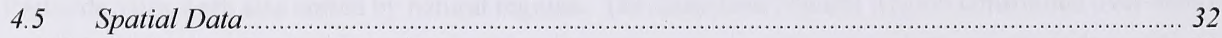

4.5.1 Linkage to Surface Water Monitoring Programs ........................................................................ 32

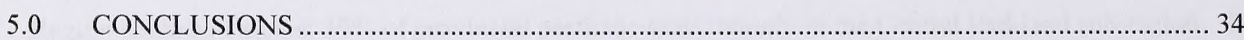

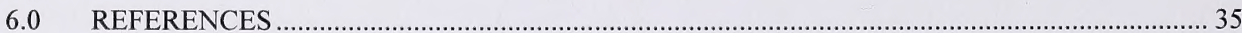


Appendix 1. Chemical Groups and Active Ingredients

Appendix 2. Alberta 2003 Pesticide Sales by Active Ingredient ......................................................... 43

Appendix 3. Pesticide sales by active ingredient and river basin . 50 


\section{TABLES}

Table 1. Pesticide Sales by Type of Use...................................................................................... 10

Table 2. Summary of Pesticide Sales by Chemical Group (all sectors) …................................................ 11

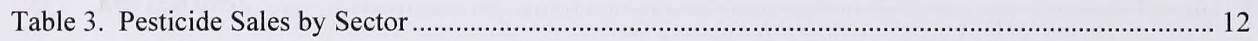

Table 4. Top 15 Agricultural Active Ingredient Sales for 2003 and 1998.............................................. 14

Table 5. Summary of Agricultural Pesticide Sales by Chemical Group .................................................. 14

Table 6. Summary of Domestic Pesticide Sales by Chemical Group ......................................................... 16

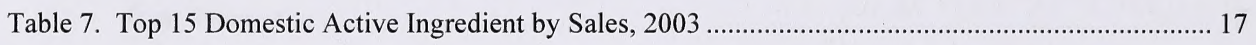

Table 8. Top 15 Commercial/Industrial Active Ingredients sold in 2003........................................... 18

Table 9. Agricultural Pesticide Sales (excluding adjuvants) by River Basin .......................................... 19

Table 10. Total Pesticide Sales by River Basin - Flow ......................................................................... 20

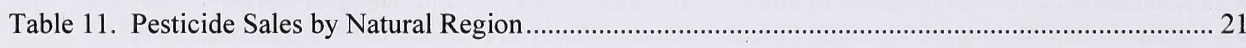

Table 12. Breakdown by Municipality of 2001 Crop (ha), Agricultural Pesticide Sales (2003 kg ai), and

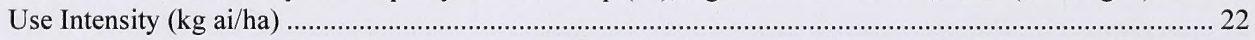

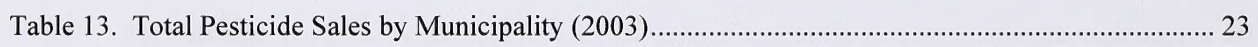

Table 14. Pesticide use comparisons 1988-2003 (excluding adjuvants) ………………………............... 28

Table 15. Pesticide use by product and type of use by province (excluding adjuvants).............................. 29

Table 16. Canola total acres harvested ('000's)(based on Canola Council 2005 data) .............................. 30

Table 17. Comparison of 1995-2002 pesticide sampling intensity by basin, and 2003 agricultural pesticide sales by basin. 
FIGURES

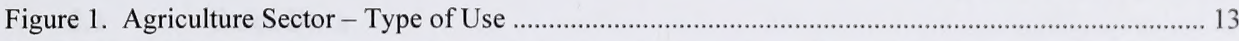

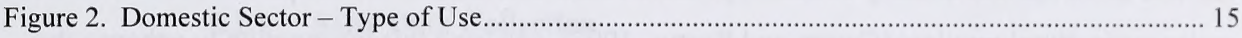

Figure 3. Commercial/Industrial Sector - Type of Use …................................................................... 18

Figure 4. Total Agricultural Pesticide Sales (excluding adjuvants) By River Basin ('000 kg ai) - $2003 \ldots . .25$

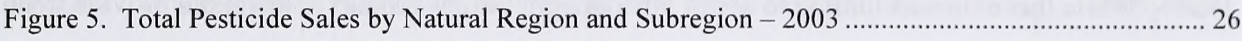

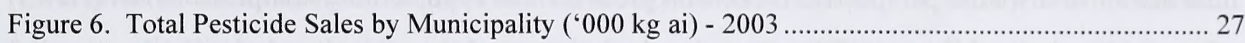

Figure 7. Alberta Canola Seeded Acres (1996-2003) _............................................................................. 30

Figure 8. Selected Canola Herbicide Sales (1988-2003) ........................................................................... 31 


\subsection{INTRODUCTION}

Alberta Environment initially collected pesticide sales information for the period 1988-1993 from major agricultural retailers (Cotton and Byrtus, 1995), and used this information to enhance the pesticide monitoring carried out by AENV in surface waters (Anderson 2005), and to assist in the development of a major surface water monitoring program conducted from 1995-1996 (CAESA 1998). While this data was limited to about $50 \%$ of agricultural product sales, it did provide trend information and spatial perspective on certain products. In 1998, a more comprehensive review of pesticide sales in Alberta was conducted and encompassed the agricultural, domestic, commercial livestock and structural sectors (Byrtus 2000). This information was used in the updating of pesticide monitoring programs, for surface water monitoring conducted by AENV, AESA, as well as treated water monitoring programs operated by AENV. In addition, domestic sales data was extracted to provide extensive information on pesticide use by major urban centres in Alberta.

In 2003, Alberta Environment undertook its third provincial scale review of pesticide sales; using the same data collection and reporting process as was implemented for 1998. Updates to the databases used for the cross referencing the sales records to chemical and spatial information was conducted.

The data in this overview will assist Alberta Environment and other provincial and federal agencies in comparisons of pesticide sales/usage information. It will also help to identify monitoring priorities for ongoing monitoring programs and assist in planning for new programs. It will also assist Alberta Environment in ensuring that the appropriate regulatory framework is in place for the pesticides in current use in Alberta.

The specific objectives of this project were:

1. To assemble pesticide sales records representing pesticide use for the calendar year 2003 .

2. To categorize pesticide sales by chemical group, sector of use, and geographic distribution 


\subsection{METHODS}

\subsection{Sales Data}

\subsubsection{Sales Data Collection}

Alberta Environment maintains a registry of pesticide vendors that retail restricted and commercial registered pesticide products, as well as wholesale distributors of domestic class products. This registry is maintained as a component of the Environmental Management System (EMS), which tracks many of the approvals and registrations issued by Alberta Environment that fall under the Environmental Protection and Enhancement Act (EPEA). Under the authority of this Act and its supporting regulations (Pesticide (Ministerial) Regulation), Alberta Environment can request pesticide sales records from vendors.

A letter was sent out to all registered vendors in Alberta and wholesale distributors in early 2004 requesting pesticide sales in Alberta for the calendar year 2003. Sales data was received throughout 2004 in various formats (hard copy and electronic). Records were received from approximately $92 \%$ of vendors sent request letters. Several vendors had changed ownership during 2003, complicating the sales data retrieval.

Hard copy records were manually entered into a standardized Excel file, while digital files were converted to the standardized database format. Regardless of the data format, the vendor approval number, product registration number, quantity sold in litres or kilograms and sector of use were recorded for each entry. Individual vendor data files were consolidated into a single sales database, which contains almost 65,000 records.

\subsubsection{Sales Data Limitations}

\section{Sector Representation}

The data from vendors that are primarily agricultural suppliers may have also contained sales to the landscape industry, the industrial sector, municipal governments, golf courses and other nonagricultural sectors. As a result, the agricultural sector may be slightly over-represented, while the other sectors may be slightly under-represented for those products that have cross-sector utilization. Products that were sold by agricultural retailers, but that were only registered for noncropland uses were classified to the Commercial/Industrial sector. 


\section{Treated Seed}

Sales of fungicide and insecticide treated seed was not targeted in this survey, however some sales records of treated seed were received, converted to a pesticide active ingredient equivalent, and reported. The collection of treated seed sales data was beyond the scope of this project, particularly as seed distribution is often done by seed vendors or seed divisions (not specifically regulated under EPEA) rather than agricultural chemical divisions of the line companies. Most of the products used for custom seed treatment at seed cleaning plants are captured in this survey.

\section{Vendor List}

The vendors surveyed were based upon the vendors contacted in 1998, along with an updated list from the EMS system, which was also cross-referenced to the list of CropLife certified warehouses, supplied by the Agricultural Warehouse Standards Association. Because of regulatory reform, not all pesticide vendors are registered under EPEA or under the CropLife warehouse program. For example, many of the livestock products have been exempted from vendor registration requirements. Therefore, the livestock product information is not complete. Also, the sales of disinfectants, anti-microbial products and wood preservatives are exempted from requiring a vendor registration, so there is virtually no sales data on those products.

\section{Domestic Products}

The sales records obtained from the agricultural and industrial sectors were considered reasonably accurate in terms of product sold, as they were obtained from systems reporting the point of sale for each product. On the other hand, domestic sales records came from distributors and wholesalers, so there is some outlet based information, and some records based on sales or shipments within the province. Most wholesale records consisted of case lots, and because it is not known how much product came out of individual store inventory in the spring, and went into inventory in the fall, it was assumed that the product shipped to the various domestic retail outlets in 2003 was sold in 2003. Also, some products were shipped through regional distribution systems, and that information was not accessed during the 2003 survey.

In the domestic sector, pet care products, spa and pool products, and most wood preservatives (paints and stains) sold in Alberta were not identified in this survey. Some miscellaneous household (indoor) pesticides were also missed in this survey, as they are classified as Schedule 4 
products, which have been exempted from the provincial regulations as far as requiring wholesale vendor registrations, or retail dispenser certification.

\section{Geographic Non-Specific Records}

Some vendors were unable to identify retail outlets for their shipments for a variety of reasons. These sales data were identified as "Alberta", and as a result, would not be included in any geographical breakdown. These records would, however, be included in sector summaries, active ingredient listings, and chemical group summaries.

\section{$2.2 \quad$ Pesticide Databases}

In order to consolidate pesticide formulation sales information down to active ingredient and to chemical group, two separate databases were also incorporated. The first of the pesticide databases was the pesticide Product database, which was originally obtained from the Pesticide Management Regulatory Agency in 1998, and updated with pesticide registrations issued up to and including 2003. Registrations for fertilizer-pesticide combinations under the Fertilizer Act were also added to this database. This database has information required for this project on the product registration number, active ingredient, guarantee, as well as product name, registration status, etc. This database currently has 15615 records. The second pesticide database was the Active database, which included active ingredient codes, active ingredient names, chemical family and chemical group. There are a total of 641 records in this database, however this includes disinfectants, antimicrobials and a number of historical active ingredients that are no longer registered or sold in Canada.

\subsection{Geographic Databases}

Four databases were used to identify the geographic distribution of pesticide sales information.

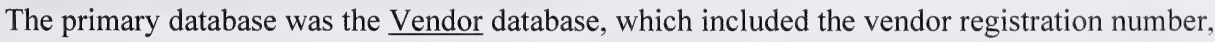
along with the vendor name and location (e.g., city, town, village or hamlet). As a number of sales records were received for vendors that do not require vendor registrations in Alberta (primarily domestic retail vendors), dummy vendor numbers were also generated for these. Dummy vendor numbers were also generated for all municipalities in Alberta to enable geographic identification of minor vendors, or sales records to end users. Another major database was the City database, which lists all the municipalities in Alberta. Associated with each municipality was the corresponding reference for rural municipality, drainage basin, and 
ecodistrict. Secondary databases included Basin (which cross-referenced drainage basin and river basins), and Natural Region (which cross-referenced ecodistrict and natural regions).

\subsection{Data Processing}

The databases and spreadsheets were imported into Microsoft Access for data processing and querying. The databases were linked by related fields to calculate active ingredient values, and subsequent data groupings by chemical group, sector of use, and geographic distribution (see Cotton and Byrtus 1995 for an example of how the calculations were done). Conversion of formulated product sales to $\mathrm{kg}$ of active ingredient (ai) is a common means of expressing pesticide sales/use in other jurisdictions (Gregoire 1997), although actual reporting is sometimes by chemical group or by sector of use instead of by quantities of individual active ingredients.

Assumptions were made with respect to pesticide formulations, such as the specific gravity of all pesticide formulations being 1.0. In 1998, Bacillus formulations were assumed to be $100 \%$ active ingredient. Information on actual percentages of active ingredient on a volume basis was obtained for products sold in 2003, so Bacillus formulations are reported here as active ingredient instead of formulated product.

Products that contain more than one active ingredient were assigned an extension number to the PCP (Pest Control Products) number for each of the active ingredients involved in both the sales and product databases. This enabled the use of the existing registration numbers with only a minor modification, and also enabled the software used for the data processing to accurately identify each component of a formulation. However, this resulted in additional records being added to the sales database to account for each active ingredient in a formulation (approximately 20,000 records).

\subsection{Data Breakdown}

In order to simplify the analysis of the data, consolidation of the data based upon type of use, chemical group and sector of use was undertaken.

\subsubsection{Type of Use}

Under the PCP Act, pesticides are classified into 39 product types (herbicides, insecticides, fungicides, etc) of products, which reflect their type of use. For the purpose of this document, the categories have been reduced to 6 primary types of use. All of the active ingredients identified in 
sales made in Alberta in 2003 are included in one of the types of use listed here. For those active ingredients that have multiple types of uses (such as thiram, which is a fungicide and a vertebrate repellent), the product is listed under its primary usage for Alberta.

- Herbicides and plant growth regulators

- Insecticides, acaracides, repellents,

- Fungicides

- Vertebrate control products and vertebrate repellents

- Adjuvants/surfactants

- Other: (Soil fumigants, wood preservatives, disinfectants, anti-microbials)

As the primary focus of this survey was on traditional pesticides, and not anti-microbial or disinfectant pesticides, sales data from industrial and domestic cleaning agents were not obtained or included, although these are also registered under the PCP Act. Adjuvants and surfactants are widely used in the agricultural industry in Alberta, so these records were included as a separate category.

\subsubsection{Chemical Group}

The chemical groupings (listed below) used for this overview are based primarily upon the groups established by the National Pesticide Sales Data Base, using an interim list dated February of 2000 (Appendix 1). This list is still under review, and could be subject to further changes. This list is derived from a variety of sources, with the main source being the list used by Quebec in their pesticide sales groupings (Gorse 1999), although there are a number of minor differences in the chemical groups used here and by Quebec. Several of these groups contain more than one chemical family. For example, the Amides, Anilines group contains compounds from the anilides, amides and benzamides families.

\section{Chemical Groupings Used In This Overview}

- Alcohols

- Amides, Anilines

- Amino Acids

- Ammoniums, Quaternary

- Aryloxyphenoxyl Acids

- Azoles, Diazoles, Oxazoles, Thiazoles, Triazoles

- Bacillus thuringiensis

- Benzimidazoles, Phenylpyrroles

- Benzonitriles, Nitriles

- Carbamates
- Carboxylic Acids

- Chlorophenols

- Chromenones

- Cyclohexanedione Oximes

- Diazines, Quinoxalines, Morpholines

- Dicarboximides, Oxathiin

- Dithiocarbamates

- Fatty Acids

- Halogenated Hydrocarbons

- Hydrocarbons

- Indanediones 
- Inorganic Coppers

- Inorganic Zincs

- Inorganics, Other

- Microbials (Other than Bt)

- Miscellaneous (Non-classified)

- Nitro Derivatives

- Oils, Mineral and Vegetable

- Organic Acids

- Organochlorines

- Organometallics

- Organophosphorous
- Phenols

- Phenoxy Acids

- Phosphonic Acids, Phosphinic Acids

- Phthalic Acids

- Pyrethroids, Pyrethrins

- Pyridines

- Sulfonylureas, Uracils

- Thiocarbamates

- Triazines, Triazinones, Tetrazines

- Urea Derivatives

\subsubsection{Sector of Use}

The intent of categorizing the sales by sector of use was to attempt to differentiate between various sectors and their relative usage of pesticides in Alberta. Initially, it was thought that the sales could be differentiated by product and by the vendor. For products such as home and garden pesticides (Domestic sector), and products used on livestock (Livestock sector), this was relatively easy. However, the sales records indicated that several of the vendors who sell agricultural products primarily, also sold herbicides that were primarily for turf, non-cropland, right of way (ROW) or landscape usage (Commercial/Industrial), and would not be used for agricultural production purposes, except perhaps for pasture renovation. These records were categorized as Commercial/Industrial.

Some products have multiple sectoral uses such as agriculture, landscaping or ROW maintenance. As the end use for these products could not be distinguished, these purchases at agricultural vendors have been included under the Agricultural sector. The resulting breakdowns therefore, are simplified and may not accurately reflect actual sectoral usage in Alberta. Some general guidance on sectoral usage was provided by the Alberta Agriculture Blue Book (AAFRD 2003a).

The sectors of use used in this report include:

- Agricultural (products sold at agricultural outlets and that had registrations for on-farm use)

- Domestic (products shipped to or sold at garden centres, hardware stores, etc)

- Commercial/Industrial (includes forestry, ROW, landscaping, golf courses, municipal)

- Livestock (products sold for use on cattle, horses, sheep, etc)

- Structural (products sold for use by exterminators). 


\subsubsection{Geographic Units}

\subsubsection{River Basins}

There are 13 major river basins that are identified in Alberta. Within these river basins are numerous sub-basins or drainage basins, which define the watersheds of major and minor tributaries. In order to assist the interpretation of pesticide monitoring data for Alberta, which is generally reported by major river basin, and sometimes by sub-basin, identification of overall pesticide usage by river basin was required. All of the municipalities in the City database were identified as to their respective sub-basin. The major river basins in Alberta used for this report are based upon PFRA basins, obtained from Alberta Agriculture and Food (Spiess 2005):

- Athabasca River

- Battle River

- Beaver River

- Bow River

- Hay River

- Milk River
- North Saskatchewan River

- Oldman River

- Peace River

- Red Deer River

- Sounding Creek

- South Saskatchewan River

\subsubsection{Natural Regions}

There are six major natural regions in Alberta, which contain a total of 21 subregions. To link pesticide sales to the various natural regions in Alberta, each municipality in the City database was allocated to an ecodistrict, which was then linked to the respective natural region in the Natural Region database. The detailed maps used to determine municipality location in relation to ecodistrict were obtained from AAFRD (2003b) and Strong and Thompson (1995). The natural regions identify different ecological zones within Alberta, which are influenced by soil type, climate, physiography, water, fauna, land use, and vegetative cover (ESWG 1995). The natural regions of Alberta (updated in 2005) are:

- Grassland

- Parkland

- Canadian Shield
- Foothills

- Rocky Mountain

- Boreal Forest

\subsubsection{Municipalities}

There are about 88 municipalities (rural municipalities, cities and national parks) in Alberta. Pesticide sales were allocated to the municipality in which the vendor was located for data analysis by geo-political boundaries. In most situations, agricultural sales made at a vendor 
located in a city were consolidated to the surrounding rural municipality (e.g., Camrose) for the purposes of sub-regional assessments and mapping purposes.

\subsection{Use Intensity}

Pesticide use intensity, ( $\mathrm{kg}$ of active ingredient used per hectare of land) is relatively inexact measurement, but it is often used to compare relative pesticide use between regions or countries with different land areas, or areas with different pesticide usage as a result of different crops requiring different pesticide inputs. It can also be used as a measure of relative pesticide use over time. In this report, pesticide sales by defined geographic area were considered representative of use, and the use intensity was calculated based on the land base for the defined geographic area. 


\subsection{RESULTS}

In 2003, a total of $9264487.7 \mathrm{~kg}$ of active ingredient was sold in Alberta. The sales data are broken down as follows.

\section{$3.1 \quad$ Type of Use}

Herbicides and plant growth regulators (PGR's) made up the majority of pesticides sold in Alberta, at $77.3 \%$ (Table 1). Although insecticides made up a greater proportion than fungicide sales in 2003 , this was primarily attributed to an extensive grasshopper outbreak, which resulted in over 3.7 $\mathrm{M}$ acres being sprayed throughout Alberta (Ball 2006). In non-outbreak years, fungicide sales would likely exceed insecticide sales by volume.

Table 1. Pesticide Sales by Type of Use

\begin{tabular}{|l|r|c|}
\hline Type of Use & \multicolumn{1}{|c|}{ Kg ai } & Percentage (\%) \\
\hline \hline Herbicides, PGR's & 7158660.3 & 77.3 \\
\hline Insecticides, Acaracides, Repellents & 433176.1 & 4.7 \\
\hline Fungicides & 319464.5 & 3.4 \\
\hline Vertebrate Control Products and Vertebrate Repellents & 1712.9 & 0.02 \\
\hline Adjuvants and Surfactants & 1350159.8 & 14.6 \\
\hline Other & 1313.9 & 0.01 \\
\hline Totals & $\mathbf{9 2 6 4} \mathbf{4 8 7 . 7}$ & $\mathbf{1 0 0}$ \\
\hline
\end{tabular}

Vertebrate control products and repellents made up a very small percentage of pesticide sales, at less than $0.02 \%$. The majority of this was for products used for controlling Richardson's ground squirrel and pocket gophers.

Adjuvants and surfactants made up the second largest group, in terms of percentage of sales. These compounds are often packaged with herbicides, and are used to enhance the effectiveness of the herbicides on the target weed(s). Although they have been categorized as a separate type of use, because they are virtually always used in conjunction with a herbicide, they could be considered a component of the Herbicide group. Changes in packaging have been implemented, where adjuvants are no longer packaged with the herbicide, and future sales reporting may not capture the complete sales records for adjuvants. On the other hand, current sales records may overestimate actual adjuvant usage, as excess adjuvant can be returned to dealers through a CropLife Canada stewardship program for adjuvants in excess of producers needs. 
The "Other" category includes sales for products that do not fit the named categories, and for which only a limited number of sales records were received. This category includes wood preservatives, disinfectants, slimicides and soil fumigants. As the disinfectants and slimicides are exempted under the provincial pesticide regulations, and the focus of the sales survey was primarily on the traditional pesticides, very little information on these products was obtained.

\subsection{Chemical Group}

The sales records were also broken down by chemical group (Table 2), as defined by the National Pesticide Sales Database groupings (Appendix 1). The chemical group with the largest proportion of sales was the Phosphonic Acids, Phosphinic Acids group at $38.1 \%$, followed by the Phenoxy Acids at $21.1 \%$. The next groups were the Hydrocarbons, and Oils, Mineral and Vegetable in the 6-7\% range. These five groups consist of the major herbicides (and adjuvants/surfactants) used in Alberta. The remaining chemical groups were all under 5\%, and 27 of the 42 chemical groups were under $1 \%$ of total sales.

Table 2. Summary of Pesticide Sales by Chemical Group (all sectors)

\begin{tabular}{|l|r|c|}
\hline Chemical Grouping & \multicolumn{1}{c|}{ Kg ai } & Percentage \% \\
\hline Phosphonic Acids, Phosphinic Acids & 3529524.0 & 38.1 \\
\hline Phenoxy Acids & 1957477.2 & 21.1 \\
\hline Oils, Mineral and Vegetable & 661102.1 & 7.1 \\
\hline Hydrocarbons & 560461.0 & 6.0 \\
\hline Benzonitriles, Nitriles & 398799.9 & 4.3 \\
\hline Carboxylic Acids & 377602.0 & 4.1 \\
\hline Organophosphorus & 270235.3 & 2.9 \\
\hline Thiocarbamates & 209626.2 & 2.3 \\
\hline Nitro Derivatives & 209618.1 & 2.3 \\
\hline Cyclohexanedione oximes & 175914.1 & 1.9 \\
\hline Aryloxyphenoxyl Acids & 124762.3 & 1.3 \\
\hline Carbamates & 106395.8 & 1.1 \\
\hline Dicarboximides, Oxathiin & 90752.2 & 1.0 \\
\hline Inorganics, Other & 81895.0 & 0.9 \\
\hline Dithiocarbamates & 72063.7 & 0.8 \\
\hline Alcohols & 66481.2 & 0.7 \\
\hline Azoles, Diazoles, Oxazoles, Thiazoles, Triazoles & 65400.2 & 0.7 \\
\hline Pyridines & 43200.0 & 0.5 \\
\hline Miscellaneous (Non-classified) & 41613.5 & 0.4 \\
\hline Urea Derivatives & 40178.6 & 0.4 \\
\hline Amides, Anilines & 37264.3 & 0.4 \\
\hline Ammoniums, Quaternary & 32000.5 & 0.3 \\
\hline Benzimadazoles, Phenylpyrroles & 29496.2 & 0.3 \\
\hline Sulfonylureas, Uracils & 21611.9 & 0.2 \\
\hline Organochlorines & 17532.1 & 0.2 \\
\hline
\end{tabular}




\begin{tabular}{|l|r|c|}
\hline Triazines, Triazinones, Tetrazines & 13703.2 & 0.1 \\
\hline Pyrethroids, Pyrethrins & 8892.1 & 0.1 \\
\hline Inorganic Coppers & 8397.3 & 0.1 \\
\hline Diazines, Quinoxalines, Morpholines & 6504.9 & 0.1 \\
\hline Fatty Acids & 2432.8 & 0.0 \\
\hline Amino Acids & 2175.6 & 0.0 \\
\hline Phthalic Acids & 572.5 & 0.0 \\
\hline Inorganic Zincs & 458.9 & 0.0 \\
\hline Organic Acids & 119.9 & 0.0 \\
\hline Bacillus thuringiensis species & 70.2 & 0.0 \\
\hline Chromenones & 64.9 & 0.0 \\
\hline Phenols & 58.1 & 0.0 \\
\hline Organometallics & 27.5 & 0.0 \\
\hline Indanediones & 2.1 & 0.0 \\
\hline Total & $\mathbf{9 2 6 4} \mathbf{4 8 7 . 7}$ & $\mathbf{1 0 0 . 0}$ \\
\hline
\end{tabular}

\subsection{Sector of Use}

Pesticide sales broken down by sector of use are listed in Table 3. As expected, agricultural use dominates pesticide sales in Alberta at $96.2 \%$. The next sector was the Commercial/Industrial sector at $3.1 \%$. Domestic pesticide sales made up only $0.6 \%$ of total sales by active ingredient. Livestock and Structural sectors combined made up less than $0.1 \%$ of all sales.

Further breakdown of the sector sales by type of use was conducted to assess if the overall trends in type of use was consistent within each sector. Figures 1-3 show the breakdowns for each sector.

Table 3. Pesticide Sales by Sector

\begin{tabular}{|l|r|c|}
\hline Sector & Kg ai & Percentage (\%) \\
\hline \hline Agriculture & $\mathbf{8 9 0 9 9 0 7 . 7}$ & 96.2 \\
\hline Commercial/Industrial & 290335.6 & 3.1 \\
\hline Domestic & 58711.7 & 0.6 \\
\hline Livestock & 2658.6 & 0.03 \\
\hline Structural & 2874.1 & 0.03 \\
\hline \hline Totals & $\mathbf{9 2 6 4 4 8 7 . 7}$ & $\mathbf{1 0 0}$ \\
\hline
\end{tabular}

\subsubsection{Agricultural Sector}

Herbicides made up the majority of pesticide use in the agricultural sector, with $77 \%$ of all sales. Adjuvants were the next highest category, at over $15 \%$ of pesticide use. As discussed earlier, adjuvants and surfactants are widely used to enhance the application and effectiveness of herbicides, and are often supplied by the manufacturer to be used in conjunction with their 
products. Insecticide and fungicide use were each below $5 \%$ of agricultural pesticide sales in Alberta.

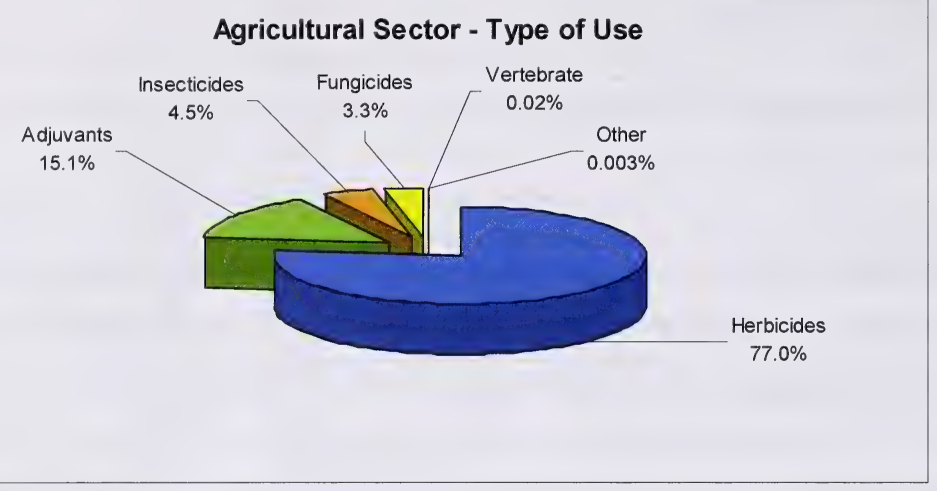

\section{Figure 1. Agriculture Sector - Type of Use}

The top 15 active ingredients sold in the agricultural market in Alberta in 2003 are listed in Table 4, with comparisons to the agricultural sales of those active ingredients in 1998. Overall, there was little change in the top selling products, although some changes were observed as a result of changes in agronomic practices or product replacements. Substantial increases $(>20 \%)$ were observed for glyphosate, MCPA, bromoxynil, glufosinate, and petroleum hydrocarbon blend used as an adjuvant. The sales of carbaryl increased significantly, mainly as a result of other grasshopper control products being taken off the market (e.g., carbofuran, trichlorfon), and the grasshopper problems experienced in 2003 throughout Alberta.

Substantial reductions in sales were observed for triallate and ethalfluralin, both of which are preemergent herbicides used for wild oat control. This is indicative of a change in agronomic practices, moving towards zero tillage (both products require incorporation after application), and a move towards herbicide tolerant canola systems, which utilize products such as glyphosate for broad spectrum weed control. 
Table 4. Top 15 Agricultural Active Ingredient Sales for 2003 and 1998

\begin{tabular}{|l|c|r|r|c|}
\hline Active Ingredient & Usage & \multicolumn{1}{c|}{$\begin{array}{c}\text { 2003 Sales } \\
\text { (kg ai) }\end{array}$} & $\begin{array}{c}\text { 1998 Sales } \\
\text { (kg ai) }\end{array}$ & $\begin{array}{c}\text { \% Change } \\
\text { (1998 to 2003) }\end{array}$ \\
\hline Glyphosate & Herbicide & 3333994.5 & 2627599.3 & $+26.9 \%$ \\
\hline MCPA & Herbicide & 1096848.9 & 884937.5 & $+23.9 \%$ \\
\hline $2,4-D$ & Herbicide & 685294.5 & 674902.6 & $+1.5 \%$ \\
\hline Petroleum Hydrocarbon Blend & Adjuvant & 559728.7 & 368704.3 & $+51.8 \%$ \\
\hline Surfactant Blend & Adjuvant & 437400.5 & 496177.7 & $-11.8 \%$ \\
\hline Bromoxynil & Herbicide & 354906.6 & 268105.3 & $+32.4 \%$ \\
\hline Triallate & Herbicide & 197221.4 & 693269.3 & $-71.6 \%$ \\
\hline Chlorpyrifos & Insecticide & 197004.7 & 215779.6 & $-8.7 \%$ \\
\hline Paraffin Base Mineral Oil & Adjuvant & 192634.4 & 192708.2 & $0.0 \%$ \\
\hline Ethalfluralin & Herbicide & 168135.0 & 452294.4 & $-62.8 \%$ \\
\hline Tralkoxydim & Herbicide & 141226.1 & 126323.5 & $+11.8 \%$ \\
\hline Imazamethabenz & Herbicide & 138551.4 & 173679.2 & $-20.2 \%$ \\
\hline Dicamba & Herbicide & 108637.8 & 118739.8 & $-8.5 \%$ \\
\hline Glufosinate & Herbicide & 106689.6 & 63400.8 & $+68.3 \%$ \\
\hline Carbaryl & Insecticide & 100955.7 & 1259.2 & $+7917.4 \%$ \\
\hline
\end{tabular}

In order to better compare the sector sales to 1998 Alberta sales, the chemical group breakdown was conducted on the agricultural pesticide sales (Table 5). The Phosphonic/Phosphinic Acids group dominated the agricultural sales at over $38 \%$, which was an increase over 1998 . The Phenoxy Acids group followed this at almost 21\%, also increasing over 1998. The Mineral and Vegetable Oils and Carboxylic Acids were next at slightly over $7 \%$ of agricultural sales.

Substantial changes in sales from 1998 were the over $5 \%$ reduction in Thiocarbamates and Nitro Derivatives (primarily triallate and trifluralin sales). Although it does not makes up a large proportion overall, the reduction in organochlorine sales (primarily lindane) from over $57,000 \mathrm{~kg}$ to just slightly over $10,000 \mathrm{~kg}$ is a significant reduction of sales in this chemical group.

Table 5. Summary of Agricultural Pesticide Sales by Chemical Group

\begin{tabular}{|l|r|r|r|r|}
\hline & \multicolumn{2}{|c|}{$\mathbf{2 0 0 3}$} & \multicolumn{2}{c|}{$\mathbf{1 9 9 8}$} \\
\hline Chemical Group & \multicolumn{1}{|c|}{ Kg ai } & \% & \multicolumn{1}{c|}{ Kg ai } & \% \\
\hline Phosphonic Acids, Phosphinic Acids & 3442310.0 & 38.6 & 2726841.7 & 30.6 \\
\hline Phenoxy Acids & 1859658.2 & 20.9 & 1628866.2 & 18.3 \\
\hline Oils, Mineral and Vegetable & 657993.3 & 7.4 & 767002.9 & 8.6 \\
\hline Hydrocarbons & 559728.7 & 6.3 & 368704.3 & 4.1 \\
\hline Benzonitriles, Nitriles & 394253.6 & 4.4 & 298994.6 & 3.3 \\
\hline Carboxylic Acids & 318789.7 & 3.6 & 365508.6 & 4.1 \\
\hline Organophosphorus & 259892.5 & 2.9 & 263784.0 & 3.0 \\
\hline Thiocarbamates & 209626.2 & 2.4 & 734218.3 & 8.2 \\
\hline Nitro Derivatives & 209618.1 & 2.4 & 682990.7 & 7.7 \\
\hline Cyclohexanedione oximes & 175914.1 & 2.0 & 187367.4 & 2.1 \\
\hline Aryloxyphenoxyl Acids & 124761.9 & 1.4 & 136306.8 & 1.5 \\
\hline Carbamates & 102450.5 & 1.1 & 10076.4 & 0.1 \\
\hline Dicarboximides, Oxathiin & 87715.7 & 1.0 & 152440.3 & 1.7 \\
\hline
\end{tabular}




\begin{tabular}{|l|r|r|r|r|}
\hline Inorganics, Other & 70452.9 & 0.8 & 135613.5 & 1.5 \\
\hline Dithiocarbamates & 69281.6 & 0.8 & 94743.2 & 1.1 \\
\hline Azoles, Diazoles, Oxazoles, Thiazoles, Triazoles & 64783.5 & 0.7 & 20110.0 & 0.2 \\
\hline Alcohols & 64641.4 & 0.7 & 103151.9 & 1.2 \\
\hline Pyridines & 43166.7 & 0.5 & 23695.6 & 0.3 \\
\hline Amides, Anilines & 33671.3 & 0.4 & 10111.2 & 0.1 \\
\hline Ammoniums, Quaternary & 31241.3 & 0.4 & 36043.9 & 0.4 \\
\hline Benzimadazoles, Phenylpyrroles & 29027.5 & 0.3 & 18169.0 & 0.2 \\
\hline Miscellaneous (Non-classified) & 22478.2 & 0.3 & 22112.0 & 0.3 \\
\hline Sulfonylureas, Uracils & 18400.1 & 0.2 & 28776.8 & 0.3 \\
\hline Triazines, Triazinones, Tetrazines & 12963.2 & 0.1 & 19098.3 & 0.2 \\
\hline Urea Derivatives & 11188.6 & 0.1 & 9015.0 & 0.1 \\
\hline Organochlorines & 10130.5 & 0.1 & 57159.3 & 0.6 \\
\hline Pyrethroids, Pyrethrins & 8239.6 & 0.1 & 2497.6 & 0.03 \\
\hline Inorganic Coppers & 8052.8 & 0.1 & 277.7 & 0.003 \\
\hline Diazines, Quinoxalines, Morpholines & 6364.3 & 0.1 & 3774.9 & 0.04 \\
\hline Amino Acids & 2120.2 & 0.02 & 1091.5 & 0.01 \\
\hline Inorganic Zincs & 435.3 & 0.005 & 44.5 & 0.0005 \\
\hline Fatty Acids & 319.2 & 0.004 & 4684.6 & 0.05 \\
\hline Phthalic Acids & 211.6 & 0.002 & 696.3 & 0.01 \\
\hline Bacillus thuringiensis species & 23.7 & 0.0003 & 0 & 0.00 \\
\hline Indanediones & 1.1 & 0.000 & 1.5 & 0.00 \\
\hline Chromenones & 0.6 & 0.000 & 7.4 & 0.00 \\
\hline Organometallics & 0 & 0.0 & 3.8 & 0.00 \\
\hline Organic Acids & 0 & 0.0 & 0.014 & 0.00 \\
\hline Totals & $\mathbf{8 0 9} \mathbf{9 0 7 . 7}$ & $\mathbf{1 0 0}$ & $\mathbf{8 9 1 3} \mathbf{9 8 1 . 7}$ & $\mathbf{1 0 0}$ \\
\hline
\end{tabular}

\subsubsection{Domestic Sector}

In the domestic sector (Figure 2), herbicides again dominated at just over $60 \%$, however insecticide sales made up a significant proportion of pesticide sales at over $35 \%$. Fungicide sales were proportionately similar to agricultural fungicide sales, at around $3-4 \%$.

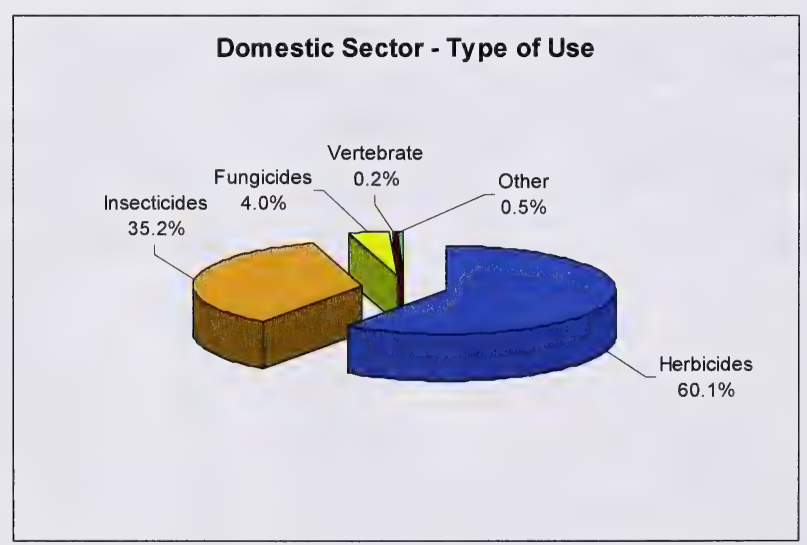

Figure 2. Domestic Sector - Type of Use 
As with the agricultural products, the domestic product sales were also broken down by chemical group (Table 6). In the Domestic sector, the Phenoxy Acids dominated at about 35\% of total pesticide sales, followed by Phosphonic/Phosphinic Acids and Inorganics. The Phenoxy Acids made up a smaller proportion of sales in 2003 compared to 1998, while the

Phosphonic/Phosphinic Acids and Inorganic Acids increased over 1998, almost doubling in proportion of sales.

Table 6. Summary of Domestic Pesticide Sales by Chemical Group

\begin{tabular}{|c|c|c|c|c|}
\hline \multirow[b]{2}{*}{ Chemical Group } & \multicolumn{2}{|c|}{2003} & \multicolumn{2}{|c|}{1998} \\
\hline & Kg ai & $\%$ & Kg ai & $\%$ \\
\hline Phenoxy Acids & 20666.3 & 35.2 & 32548.9 & 44.7 \\
\hline Phosphonic Acids, Phosphinic Acids & 11012.9 & 18.8 & 6929.9 & 9.5 \\
\hline Inorganics, Other & 10416.1 & 17.7 & 7504.9 & 10.3 \\
\hline Organophosphorus & 3672.5 & 6.3 & 7425.5 & 10.2 \\
\hline Amides, Anilines & 3413.3 & 5.8 & 3972.2 & 5.5 \\
\hline Carbamates & 3265.2 & 5.6 & 1457.6 & 2.0 \\
\hline Miscellaneous (Non-classified) & 1539.3 & 2.6 & 856.9 & 1.2 \\
\hline Fatty Acids & 893.1 & 1.5 & 1231.6 & 1.7 \\
\hline Oils, Mineral and Vegetable & 878.9 & 1.5 & 3005.9 & 4.1 \\
\hline Hydrocarbons & 729.5 & 1.3 & 2782.3 & 3.8 \\
\hline Carboxylic Acids & 453.4 & 0.8 & 716.1 & 1.0 \\
\hline Pyrethroids, Pyrethrins & 386.6 & 0.7 & 128.3 & 0.2 \\
\hline Phthalic Acids & 313.3 & 0.5 & 206.8 & 0.3 \\
\hline Triazines, Triazinones, Tetrazines & 291.0 & 0.5 & 647.9 & 0.9 \\
\hline Dithiocarbamates & 204.2 & 0.4 & 563.7 & 0.8 \\
\hline Alcohols & 192.2 & 0.3 & 0.02 & 0.0 \\
\hline Inorganic Coppers & 190.9 & 0.3 & 450.5 & 0.6 \\
\hline Chromenones & 62.5 & 0.1 & 168.1 & 0.2 \\
\hline Phenols & 58.1 & 0.1 & 805.2 & 1.1 \\
\hline Organochlorines & 38.3 & 0.07 & 194.9 & 0.3 \\
\hline Diazines, Quinoxalines, Morpholines & 12.2 & 0.02 & 12.7 & 0.02 \\
\hline Inorganic Zincs & 9.8 & 0.02 & 40.0 & 0.06 \\
\hline Bacillus thuringiensis species & 6.2 & 0.01 & $95.0 *$ & 0.1 \\
\hline Benzimadazoles, Phenylpyrroles & 3.4 & 0.006 & 69.7 & 0.1 \\
\hline Azoles, Diazoles, Oxazoles, Thiazoles, Triazoles & 1.96 & 0.003 & 34.1 & 0.05 \\
\hline Indanediones & 0.3 & 0.001 & 0.3 & 0.00 \\
\hline Pyridines & 0.045 & 0.000 & 6.3 & 0.01 \\
\hline Aryloxyphenoxyl Acids & 0.015 & 0.000 & 0.02 & 0.00 \\
\hline Ammoniums, Quaternary & 0.005 & 0.000 & 3.9 & 0.01 \\
\hline Amino Acids & 0.003 & 0.000 & 0.014 & 0.00 \\
\hline Benzonitriles, Nitriles & 0.0 & - & 147.6 & 0.2 \\
\hline Urea Derivatives & 0.0 & - & 14.7 & 0.02 \\
\hline Sulfonylureas, Uracils & 0.0 & - & 1.5 & 0.00 \\
\hline Nitro Derivatives & 0.0 & - & 1.2 & 0.00 \\
\hline Organometallics & 0.0 & - & 0.13 & 0.00 \\
\hline Totals & 58711.7 & 100 & 72024.4 & 100 \\
\hline
\end{tabular}

* Bacillus active ingredient concentrations calculated differently in 1998 and 2003. See Section XXX. 
It should be noted that there are some gaps in the domestic sales data, particularly in the herbicide sales, making direct comparisons between the two years difficult. The trends are illustrative however, particularly in the reduction of the Organophosphorus group, and increase in the Carbamates group, reflecting deregistration of the domestic organophosphate insecticides and partial substitution with carbamate insecticides.

The top domestic products sold in 2003 are listed in Table 7. Turf herbicides dominated (2,4-D and mecoprop), while glyphosate sales were also high. Glyphosate (and glufosinate) sales have increased as other total vegetation control products (atrazine, bromacil, etc) have been replaced. Silicon dioxide sales are also high in 2003 , as products containing this active ingredient have been more widely utilized for insect control in indoor situations.

Table 7. Top 15 Domestic Active Ingredient by Sales, 2003

\begin{tabular}{|l|r|}
\hline Domestic active ingredient & Kg ai \\
\hline 2,4-D & 14392.5 \\
\hline Glyphosate & 10448.5 \\
\hline Silicon dioxide salt water fossils & 7509.2 \\
\hline Mecoprop & 6273.8 \\
\hline DEET & 3413.3 \\
\hline Carbaryl & 3151.9 \\
\hline Malathion & 1667.8 \\
\hline Ferrous sulfate & 1593.4 \\
\hline Diazinon & 1292.6 \\
\hline Acetic acid & 1130.5 \\
\hline Mineral oil (Insecticidal or Adjuvant) & 838.9 \\
\hline Soap (Insecticidal) & 815.8 \\
\hline Sulphur (Fungicide) & 722.8 \\
\hline Asphalt solids & 591.9 \\
\hline Glufosinate & 564.4 \\
\hline
\end{tabular}

\subsubsection{Commercial/Industrial Sector}

In the Commercial/Industrial Sector, herbicides again dominated at $90 \%$ of pesticide sales (Figure 3 ). Insecticides made up just over $2 \%$. Fungicide sales were proportionately slightly higher in this sector, at over $6 \%$, reflecting fungicide sales to the golf course industry. Table 8 provides a more detailed breakdown of the top 15 active ingredients that were classified as being sold and used in the commercial/industrial sectors, and reflects the dominance of products sold and used for industrial site and right-of-way maintenance. 


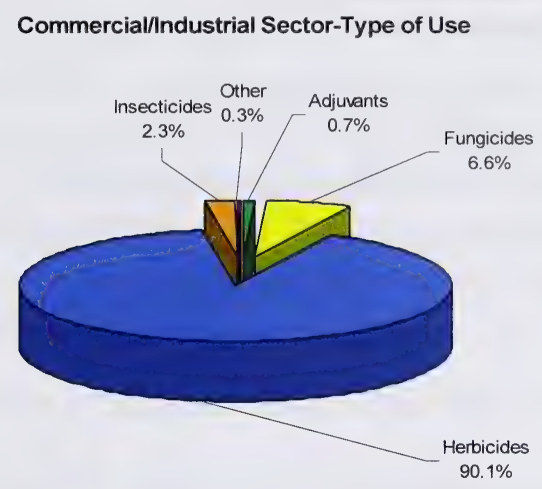

Figure 3. Commercial/Industrial Sector - Type of Use

Table 8. Top 15 Commercial/Industrial Active Ingredients sold in 2003

\begin{tabular}{|l|r|}
\hline Commercial/Industrial Active Ingredient & Kg ai \\
\hline Glyphosate & 75379.1 \\
\hline $2,4-D$ & 63670.6 \\
\hline Triclopyr & 29625.6 \\
\hline Diuron & 28960.0 \\
\hline Acrolein & 16981.4 \\
\hline Picloram & 13302.3 \\
\hline Dicamba & 12344.2 \\
\hline Mecoprop & 12288.0 \\
\hline Quintozene & 6829.0 \\
\hline Chlorothalonil & 4363.5 \\
\hline Bromacil & 3051.6 \\
\hline Iprodione & 2109.9 \\
\hline Thiram & 1908.8 \\
\hline Imazypyr & 1675.8 \\
\hline Mineral oil (Insecticidal or Adjuvant) & 1394.8 \\
\hline
\end{tabular}

\subsubsection{Other Sectors}

Pesticide sales in the Livestock sector consisted of primarily insecticides. The Structural sector also was dominated by insecticide sales, with a small quantity of vertebrate control products. 


\subsection{Geographic Distributions}

\subsubsection{Drainage Basin}

\subsubsection{Agricultural Usage}

Sales of all agricultural products (excluding adjuvants) were broken down by drainage basin (Table 9 and Figure 4). The Oldman River basin had the highest proportion of agricultural pesticide sales, at $21.4 \%$, followed by the Red Deer River basin, the North Saskatchewan River basin, and the Battle River basin. The Peace River basin had just below $10 \%$ of total agricultural pesticide sales, while the remaining basins were all below $10 \%$.

Table 9. Agricultural Pesticide Sales (excluding adjuvants) by River Basin

\begin{tabular}{|l|r|c|}
\hline River Basin & \multicolumn{1}{|c|}{ Kg ai } & (\%) \\
\hline Oldman River & 1615182.5 & 21.4 \\
\hline Red Deer River & 1334005.1 & 17.6 \\
\hline North Saskatchewan River & 1137851.8 & 15.0 \\
\hline Battle River & 1108136.4 & 14.6 \\
\hline Peace River & 731480.1 & 9.7 \\
\hline South Saskatchewan River & 647561.2 & 8.6 \\
\hline Bow River & 536221.4 & 7.1 \\
\hline Athabasca River & 234328.2 & 3.1 \\
\hline Sounding Creek & 113392.8 & 1.5 \\
\hline Beaver River & 64767.2 & 0.9 \\
\hline Milk River & 34858.4 & 0.5 \\
\hline Non-specific basin & 4069.1 & 0.05 \\
\hline Alberta & $\mathbf{7 5 6 1 ~ 8 5 3 . 9}$ & $\mathbf{1 0 0}$ \\
\hline
\end{tabular}

\subsubsection{Total Pesticide Usage}

Another factor that helps to relate the size and scale of drainage basins and pesticide use is river discharge and mean annual flows. A higher mean annual flow in relation to overall pesticide use would indicate greater potential for dilution and less potential for water quality guideline exceedences. Mean monthly discharges (over various reporting periods) were obtained from the Water Survey of Canada (2005), converted to mean annual flow with an Excel macro, and are listed in Table 10. The rivers with the highest mean annual flow have the greatest dilution capacity, and other things being equal, should have lower concentrations of pesticide residues. Also listed is the gross drainage area associated with the specific gauging station for each basin, and a calculated mean runoff value (runoff volume divided by drainage area)(Martin 2001). The mean annual runoff reflects the relative differences in precipitation, flow and basin size. For 
example, the mean annual flow of $1780 \mathrm{dam}^{3}$ for Sounding Creek, spread equally over the 2986 $\mathrm{km}^{2}$, works out to $0.6 \mathrm{~mm}$ of water, which is comparable to a very light rainfall, and virtually no runoff from the landscape. On the other hand, the $221.3 \mathrm{~mm}$ of calculated runoff for the Peace River basin would suggest that there is high potential for runoff from the landscape, and subsequently mobilizing soil particles, pesticides, nutrients, and other compounds that can impact water quality in the basin. However, these are calculated values to illustrate relative differences between basins, and do not reflect on large storm runoff events, which can make up a substantial portion of the water borne contaminants moved from the landscape to the water bodies.

The highest pesticide use intensity is found in the Sounding Creek basin, one of the smallest basins in Alberta. However, this is a very dry area of the province, and Sounding Creek has only intermittent flow throughout the year, because of the low precipitation in this basin $(321.5$ $\mathrm{mm}$ /year at Oyen -1971-2000 annual average). As well, this stream originates in the prairies, and does not have the higher elevation headwaters that provide much of the base flow for the other river basins in Alberta.

Table 10. Total Pesticide Sales by River Basin - Flow

\begin{tabular}{|c|c|c|c|c|c|}
\hline River Basin (gauging station used) & Kg ai & $\begin{array}{c}\text { Mean } \\
\text { Annual Flow } \\
\text { Volume } \\
\left(\text { dam }^{3}\right)\end{array}$ & $\mathrm{Kg} / \mathrm{dam}^{3}$ & $\begin{array}{c}\text { Gross } \\
\text { Drainage, } \\
\text { by station } \\
\left(\mathrm{km}^{2}\right)\end{array}$ & $\begin{array}{l}\text { Mean } \\
\text { Annual } \\
\text { Runoff } \\
(\mathrm{mm})\end{array}$ \\
\hline Milk River (Int. Border - East crossing) & 41913.2 & 311000 & 0.135 & 6490 & 48 \\
\hline South Saskatchewan River (Hwy 41) & 787052.5 & 5180000 & 0.152 & 71145 & 72.8 \\
\hline Oldman River (at mouth) & 1920942.9 & 2180000 & 0.881 & 27504 & 79.2 \\
\hline Bow River (near mouth) & 650317.2 & 2760000 & 0.235 & 25303 & 108.9 \\
\hline Red Deer River (at Empress) & 1552223.6 & 1760000 & 0.882 & 44700 & 39.4 \\
\hline Sounding Creek (at Oyen) & 128877.4 & 1780 & 72.403 & 2986 & 0.6 \\
\hline Battle River (near Sask. border) & 1312404.8 & 194000 & 6.765 & 25077 & 7.8 \\
\hline North Saskatchewan River (Lea Park) & 1362779.6 & 6810000 & 0.200 & 47756 & 119.3 \\
\hline Beaver River (Cold Lake Reserve) & 70728.4 & 597000 & 0.118 & 14511 & 41.2 \\
\hline Athabasca River (below Ft. McMurray) & 304878.8 & 19900000 & 0.015 & 132622 & 150.4 \\
\hline Peace River (Peace Point) & 918463.9 & 66500000 & 0.014 & 300337 & 221.3 \\
\hline Hay River (near Meander River) & 0.45 & 2240000 & -- & 36903 & 60.7 \\
\hline Non-specific basin & 213905.0 & N/A & $\mathrm{N} / \mathrm{A}$ & $\mathrm{N} / \mathrm{A}$ & N/A \\
\hline Alberta & 9264487.7 & & & & \\
\hline
\end{tabular}

$$
\mathrm{Dam}^{3}=\text { cubic decametre }=1000 \mathrm{~m}^{3}
$$

The next highest basin in relation to pesticide usage and average annual flow is the Battle River basin, at $6.76 \mathrm{~kg} / \mathrm{dam}^{3}$. This basin is adjacent to the Sounding Creek basin, and also flows through the southern and eastern portion of the Central Parkland and Dry Mixedgrass regions of 
the province. This basin also originates on the prairies at Battle Lake, and is dependent upon local snowfall and summer precipitation for primary inputs to the basin.

The other basins are all below $1 \mathrm{~kg} / \mathrm{dam}^{3}$, which are reflective of their higher annual flows. Most of these basins (the exception being the Beaver River) originate in the foothills or the Rocky Mountains, in whole or in part. The mainstems or tributaries that originate at higher elevations usually supply a major proportion of the base flow for these basins.

\subsubsection{Pesticide Sales by Natural Region}

Pesticide sales were also broken down by natural region (Figure 5) to assess pesticide sales/usage in relation to the natural regions in Alberta, which represent areas of comparable soils, climate and vegetation (Table 11). This information is of interest in relation to cropping practices that are often comparable within these regions.

Pesticide sales were concentrated in four natural regions in Alberta. The largest amount of pesticide sold, at over $35 \%$ of provincial sales, was the Central Parkland region. The Dry Mixedgrass region was next at $19.8 \%$, followed by the Mixedgrass region at $15.3 \%$, and the Dry Mixedwood region at $12.2 \%$.

Table 11. Pesticide Sales by Natural Region

\begin{tabular}{|l|l|r|c|}
\hline Natural Region & Sub Region & Kg ai & \% \\
\hline Alberta (non-specific region) & & $\mathbf{2 1 3} \mathbf{9 0 5 . 0}$ & $\mathbf{2 . 3}$ \\
\hline Boreal & Central Mixedwood & 31486.3 & 0.3 \\
\hline & Dry Mixedwood & 1126572.7 & 12.2 \\
\hline Boreal Total & Lower Boreal Highlands & 0.5 & 0.0 \\
\hline Foothills & & $\mathbf{1 1 5 8 0 5 9 . 5}$ & $\mathbf{1 2 . 5}$ \\
\hline & Lower Foothills & 10557.4 & 0.1 \\
\hline Foothills Total & Upper Foothills & 29.1 & 0.0 \\
\hline Grassland & & $\mathbf{1 0 5 8 6 . 5}$ & $\mathbf{0 . 1}$ \\
\hline & Dry Mixedgrass & 1831323.8 & 19.8 \\
\hline & Foothills Fescue & 711924.8 & 7.7 \\
\hline Grassland Total & Mixedgrass & 1414122.2 & 15.3 \\
\hline Parkland & Northern Fescue & 328584.0 & 3.5 \\
\hline & & $\mathbf{4 2 8 5 9 5 4 . 8}$ & $\mathbf{4 6 . 3}$ \\
\hline & Central Parkland & 3258822.0 & 35.2 \\
\hline Parkland Total & Foothills Parkland & 2113.7 & 0.0 \\
\hline Rocky Mountain & Peace River Parkland & 334291.9 & 3.6 \\
\hline Total & & $\mathbf{3 5 9 5 2 2 7 . 6}$ & $\mathbf{3 8 . 8}$ \\
\hline
\end{tabular}




\subsubsection{Pesticide Sales by Municipality}

Pesticide sales were broken out by rural municipality to provide a detailed geo-administrative overview of sales, using municipal boundaries that are familiar to many individuals and various levels of government. The largest volume of sales (agricultural products excluding adjuvants) occurred in the County of Lethbridge and the MD of Taber $(>500,000 \mathrm{~kg}$ ai), which are major supply and distribution centres for southern Alberta, particularly the irrigated region of Alberta. Municipalities with greater than $300000 \mathrm{~kg}$ ai of sales were the Counties of Cypress, Forty Mile, Kneehill, Vulcan, and Vermilion River. These are large municipalities with the highest proportion of total crop area in Alberta (AAFRD 2002). Data on primary crops grown in 2001 in the six municipalities with highest sales was derived from AAFRD (2002)(Table 12).

Table 12. Breakdown by Municipality of 2001 Crop (ha), Agricultural Pesticide Sales (2003 $\mathrm{kg} \mathrm{ai),} \mathrm{and} \mathrm{Use} \mathrm{Intensity} \mathrm{(kg} \mathrm{ai/ha)}$

\begin{tabular}{|c|c|c|c|c|c|}
\hline Crop Group & Lethbridge & Taber & Kneehill & Forty Mile & $\begin{array}{l}\text { Vermilion } \\
\text { River }\end{array}$ \\
\hline $\begin{array}{l}\text { Cereals (Wheat, oats, } \\
\text { barley, etc) }\end{array}$ & 149430 & 116728 & 170798 & 202576 & 169910 \\
\hline $\begin{array}{l}\text { Oilseeds (Canola, } \\
\text { flaxseed, mustard) }\end{array}$ & 9195 & 6576 & 24511 & 4159 & 59633 \\
\hline $\begin{array}{l}\text { Other Field Crops } \\
\text { (Potatoes, Peas, Sugar } \\
\text { Beets, etc) }\end{array}$ & 14432 & 44901 & 15943 & 31358 & 18834 \\
\hline Vegetables (Sweet corn) & 421 & 3172 & 11 & 5 & 27 \\
\hline Hay and Forage & 35356 & 26587 & 14872 & 12854 & 37598 \\
\hline $\begin{array}{l}\text { Total Hectares in Crop } \\
\text { Land (2001) }\end{array}$ & 208834 & 197964 & 226135 & 250682 & 286002 \\
\hline $\begin{array}{l}\text { Agric. Sales (kg ai) } \\
\text { (excl. adjuvant) }\end{array}$ & 544549.0 & 511990.1 & 338871.2 & 329666.2 & 318933.7 \\
\hline \begin{tabular}{l|l}
$\begin{array}{l}\text { Use Intensity } \\
(\mathrm{Kg} / \mathrm{ha})\end{array}$ & 2003 \\
\end{tabular} & 2.61 & 2.59 & 1.50 & 1.31 & 1.11 \\
\hline
\end{tabular}

Acreages for major crop groups varied among municipality, however cereals (primarily wheat) dominated in each municipality. Oilseeds (primarily canola) had relatively high acreage in Vermilion River and Kneehill, but relatively low acreage in Taber and Lethbridge. Potatoes and sugar beets accounted for most of the Other Field Crops grown in Taber and Lethbridge, while field peas and dry beans were extensively grown in the other municipalities. Vegetable production was predominately in the irrigated municipalities of Taber and Lethbridge. The range 
of crop types in various municipalities influences the type of pesticides used, as well as the use intensity (rate and frequency of application). Potatoes and sugar beets use very different products than cereals and oilseeds, and pesticide use is often more intensive on these types of crops for disease suppression, weed control and insect control. This is reflected in the use intensities for Taber and Lethbridge, which are relatively high at over $2.5 \mathrm{~kg} / \mathrm{ha}$. These municipalities may also serve as regional supply centres, so the use intensities for these two may be a slight overestimation.

Total sales (all sectors and all products) for all of the municipalities in Alberta are summarized in Table 13.

Table 13. Total Pesticide Sales by Municipality (2003)

\begin{tabular}{|l|c|l|l|l|c|}
\hline Municipality & Kg ai & Municipality & Kg ai & Municipality & Kg ai \\
\hline Lethbridge & 660379.7 & Ponoka & 124422.9 & Lacombe & 44670.9 \\
\hline Taber & 598434.0 & Fairview & 119651.5 & Acadia & 42785.2 \\
\hline Forty Mile & 417479.1 & Strathcona & 119082.3 & City of Calgary & 38858.8 \\
\hline Kneehill & 406928.1 & Stettler & 115194.3 & Big Lakes & 38332.3 \\
\hline Vermilion River & 383559.5 & Sturgeon & 114246.5 & Athabasca & 38268.8 \\
\hline Cypress & 343612.5 & Drumheller & 108843.3 & Lac Ste. Anne & 30013.2 \\
\hline Wheatland & 341133.5 & Provost & 107148.9 & Special Area 2 & 28812.6 \\
\hline Vulcan & 316864.4 & Spirit River & 105029.7 & Woodlands & 22658.2 \\
\hline Flagstaff & 289797.1 & Warner & 98277.6 & Clear Hills & 22342.6 \\
\hline Camrose & 276414.7 & Two Hills & 91165.0 & Thorhild & 21187.5 \\
\hline Rocky View & 235823.0 & Leduc & 85827.5 & City of Edmonton & 12724.7 \\
\hline Alberta (non-specific) & 213905.0 & Starland & 85809.3 & Saddle Hills & 10169.8 \\
\hline Red Deer & 188944.4 & Wetaskiwin & 84413.2 & Greenview & 8530.6 \\
\hline Grande Prairie & 188080.0 & Paintearth & 72809.5 & Lesser Slave River & 4325.6 \\
\hline Minburn & 182530.3 & Northern Lights & 72407.3 & Clearwater & 2896.7 \\
\hline Beaver & 181192.2 & Mackenzie & 71509.1 & Opportunity & 1934.1 \\
\hline Willow Creek & 181143.9 & Parkland & 67481.5 & Yellowhead & 666.4 \\
\hline Newell & 169869.6 & Birch Hills & 67222.1 & Lakeland & 428.5 \\
\hline Foothills & 156080.5 & Northern Sunrise & 65894.4 & Wood Buffalo & 397.8 \\
\hline Special Area 3 & 153703.8 & St. Paul & 65886.9 & Brazeau & 267.7 \\
\hline Lamont & 151114.8 & Barrhead & 61114.0 & Ranchland & 247.6 \\
\hline Wainwright & 145214.0 & Special Area 4 & 60975.0 & Bighorn & 137.7 \\
\hline Mountain View & 144397.3 & Bonnyville & 56517.4 & Jasper Nat. Park & 130.5 \\
\hline Smoky River & 133701.0 & Peace & 51992.2 & Banff Nat. Park & 10.1 \\
\hline Westlock & 132220.1 & Smoky Lake & 51740.8 & Elk Island Nat. Park & 1.2 \\
\hline Cardston & 129603.7 & Pincher Creek & 46900.3 & & $\mathbf{9 2 6 4 4 8 7 . 7}$ \\
\hline & & & & Total & \\
\hline
\end{tabular}


In 1998, there were several municipalities that did not have any sales associated with them, as there were no vendors in those municipalities, even though there were agricultural operations in the municipality. Since then, vendors have set up retail outlets in those municipalities, and a slightly more representative distribution of sales (at least for the agricultural sector) was observed for 2003. Pesticides sold in the National Parks were primarily lawn and garden products. A graphical depiction of pesticide sales with municipal boundaries is given in Figure 6 . 


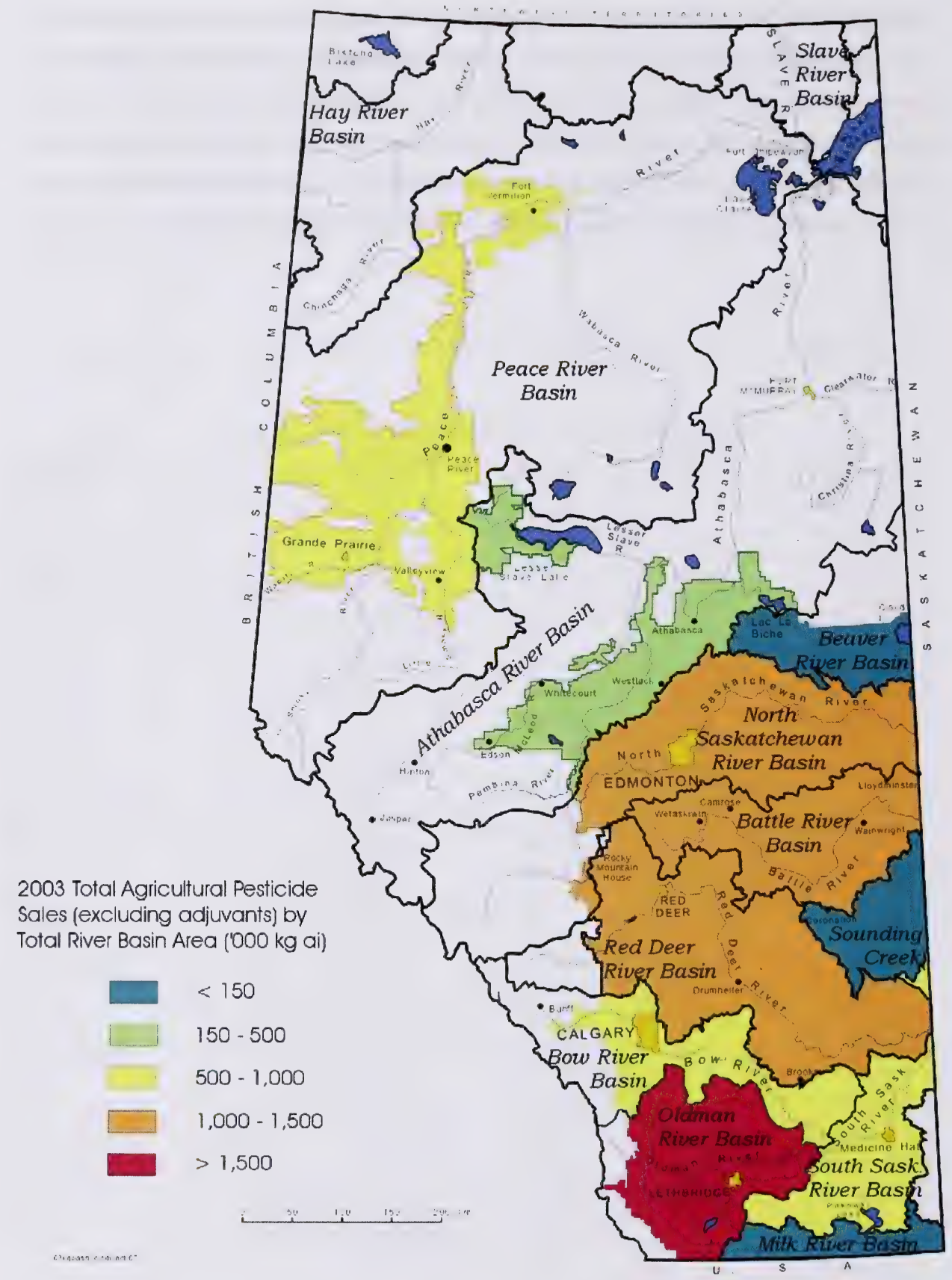

Figure 4. Total Agricultural Pesticide Sales (excluding adjuvants) By River Basin ('000 kg ai) - 2003 


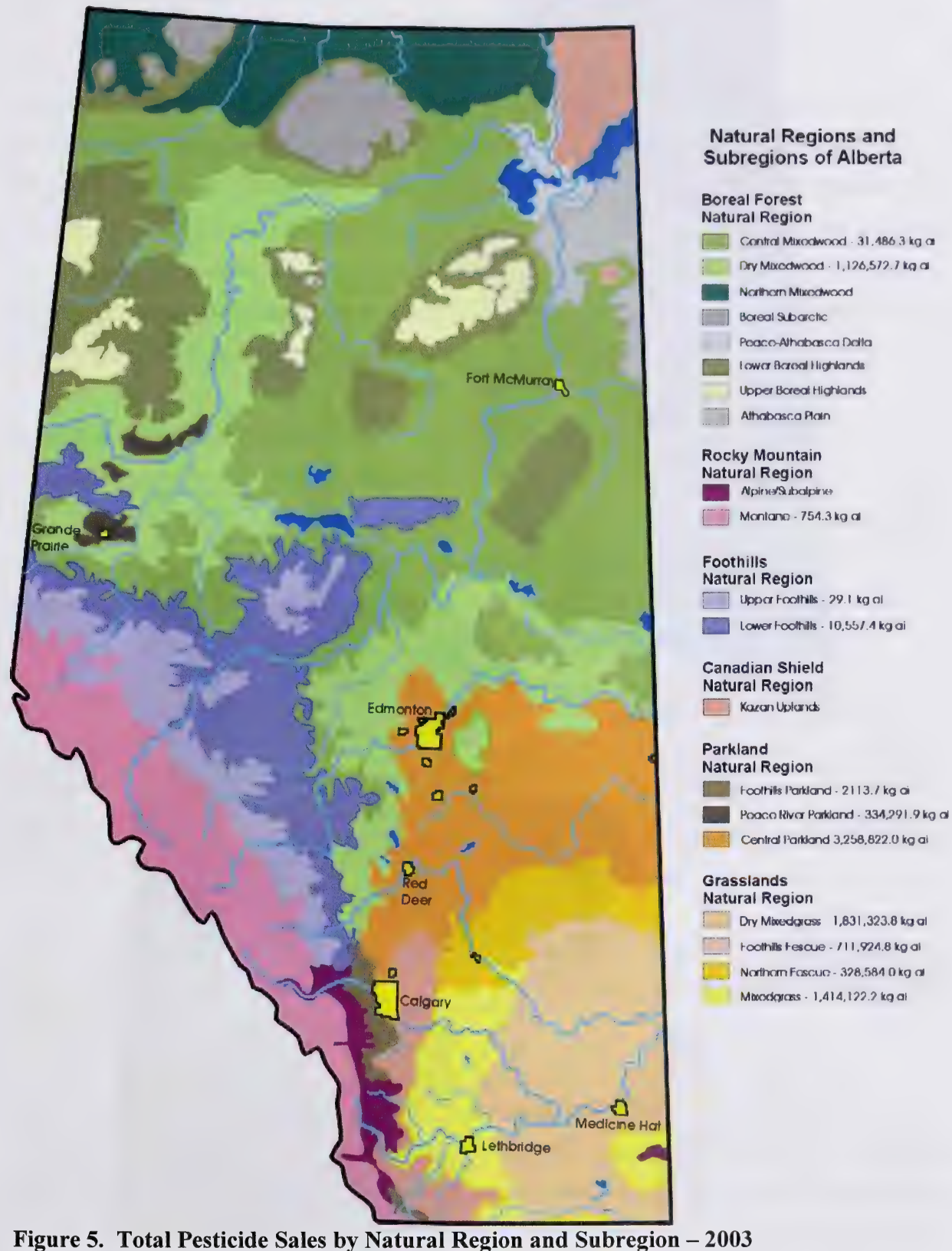

Figure 5. Total Pesticide Sales by Natural Region and Subregion - 2003 


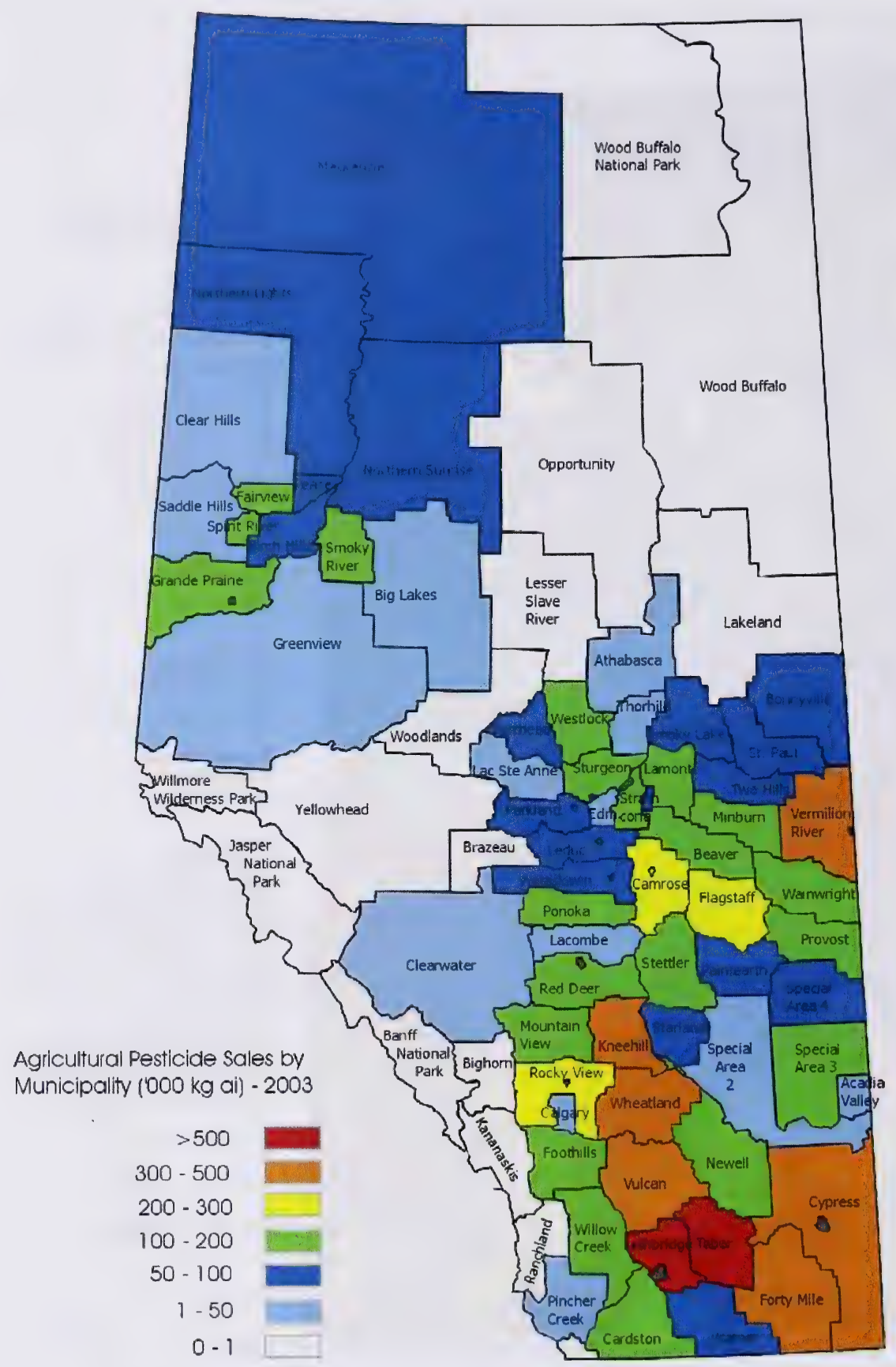

Figure 6. Total Pesticide Sales by Municipality ('000 kg ai) - 2003 


\subsection{DISCUSSION}

\subsection{Use Intensity-Alberta}

The first pesticide sales survey was conducted in Alberta for 1988 to 1993 for agricultural products only; it was followed by a comprehensive multi-sector survey in 1998 and again in 2003. The 1988 to 1993 sales data were based upon data obtained from the major line companies operating in Alberta at the time (e.g., grain handling companies). It did not include the sales data from independent dealers, which was estimated to make up approximately half of the market at the time, so the values listed are the reported sales doubled. The 1998 and 2003 surveys includes data from the line companies and independent dealers, and are much more comprehensive.

Total agricultural sales for those years were determined, and correlated to cropland information obtained from the Census of Agriculture, also carried out every 5 years (Pekalski 1995, AAFRD 2002). The timing of the Census of Agriculture (years ending in 1 and 6) and the pesticide sales survey (years ending in 3 and 8 ) do not match, but the closest time periods are used for comparing and calculating overall agricultural pesticide use intensity for Alberta.

Table 14. Pesticide use comparisons 1988-2003 (excluding adjuvants)

\begin{tabular}{|l|l|l|l|l|}
\hline & $\mathbf{1 9 8 8}$ & $\mathbf{1 9 9 3}$ & $\mathbf{1 9 9 8}$ & $\mathbf{2 0 0 3}$ \\
\hline Ag Pesticide Sales (kg ai) & 6956950 & 7491440 & 7588662 & 7561854 \\
\hline $\begin{array}{l}\text { Cropland area (ha)(census } \\
\text { survey year in brackets) }\end{array}$ & $\begin{array}{l}9162850 \\
(1986)\end{array}$ & $\begin{array}{l}9292374 \\
(1991)\end{array}$ & $\begin{array}{l}9,546,886 \\
(1996)\end{array}$ & $\begin{array}{l}9728527 \\
(2001)\end{array}$ \\
\hline $\begin{array}{l}\text { Pesticide use intensity } \\
\text { (kg/ha) }\end{array}$ & 0.76 & 0.81 & 0.79 & 0.78 \\
\hline
\end{tabular}

Overall agricultural pesticide use intensity has not changed much in Alberta over the past 15 years. There has been a slight increase in overall pesticide sales, but the calculated pesticide use intensity tends to remain near $0.8 \mathrm{~kg} / \mathrm{ha}$.

More detailed breakdown of pesticide sales by municipality (Figure 6) and calculated use intensity (Table 12) shows that high sales areas correspond to high use areas because of cropping practices in the area. For example, higher regional pesticide use intensity occurs in municipalities where irrigation farming is important, and where crop production and crop inputs for crops such as potatoes, sugar beets, and corn are higher than most dryland agricultural areas of the province. 


\subsection{Pesticide Use - Other Regions}

A recent report by Environment Canada surveyed the provinces to determine what information was available on pesticides through sales or use surveys (Brimble et al. 2005). Most provinces (except Saskatchewan) conduct sales or use surveys annually, or on regular basis. A synopsis of the pesticide sales/use by province is presented in Table 15 .

Alberta reports the highest overall sales, although it is anticipated that Saskatchewan would be higher, if they had a reporting program. The Prairies, Ontario and Nova Scotia use predominately herbicides, while New Brunswick and P.E.I. reported using primarily fungicides (related to potato acreage). Newfoundland reported mainly insecticide use for biting fly control.

Table 15. Pesticide use by product and type of use by province (excluding adjuvants)

\begin{tabular}{|l|c|c|c|c|c|c|l|}
\hline Province & Year & Total & Herbicide & Insecticide & Fungicide & Other & Comments \\
\hline BC & 2003 & 1061185 & 286423 & 408662 & 304682 & 61471 & $\mathrm{Ag} /$ For/Comm* \\
\hline Alberta & 2003 & 7561854 & 6861274 & 400451 & 298362 & 1768 & $\mathrm{Ag}$ only \\
\hline Saskatchewan & -- & -- & -- & -- & -- & -- & No sales survey \\
\hline Manitoba & 2003 & 3580536 & 3172807 & 97518 & 310073 & -- & $\begin{array}{l}\text { Based on Crop } \\
\text { Insurance } \\
\text { database-not } \\
\text { sales }\end{array}$ \\
\hline Ontario & 2003 & 4218238 & 3348118 & 81775 & 313912 & 474433 & Ag use survey \\
\hline Quebec & 2001 & 2291716 & -- & -- & -- & -- & No breakdown \\
\hline Nova Scotia & 2003 & 441609 & 299247 & 37994 & 59341 & 42568 & $\mathrm{Ag} /$ For/Comm \\
\hline $\begin{array}{l}\text { New } \\
\text { Brunswick }\end{array}$ & 2003 & 921138 & 236466 & 52926 & 482986 & 146077 & $\mathrm{Ag} /$ For/Comm \\
\hline P.E.I. & 2002 & 814103 & 111237 & 35004 & 667862 & -- & \\
\hline Newfoundland & 2003 & 42400 & 4023 & 34992 & 511 & 2944 & \\
\hline
\end{tabular}

*Ag/For/Comm - Agricultural/Forestry/Commercial

Data from the U.S. for 2001 showed that nationally, about 888 million pounds (403 million $\mathrm{kg}$ ) of active ingredient was used in the agricultural, industrial/commercial, and home and garden sectors (EPA 2004). Agriculture made up $76 \%$ of the usage, compared to over $96 \%$ in Alberta. Of the total amount, $62.3 \%$ of active ingredient used was herbicides, compared to $78 \%$ in Alberta. These differences reflect the differences in crops, pests and crop protection inputs used in the U.S. as compared to Alberta, and should be considered during comparisons of the industries in the two jurisdictions. 


\subsection{Cropping Practices}

Seeding of herbicide tolerant canola in Alberta has influenced pesticide use over the past 10 years. Prior to herbicide tolerant canola coming onto the market, multiple herbicide mixtures and applications were required to control various broadleaf and grassy weeds in canola. Herbicide tolerant canola has allowed full spectrum weed control with a single product or a mixture of two (primarily glyphosate, although glufosinate and the imidazolinones such as imazethapyr, imazamox, and imazapyr have found niches). Agricultural Financial Services Corporation (Alberta) collects some cropping information on canola varieties based on insurance records, which are estimated to cover about $3 / 4$ of the total canola (Brassica napus and B. rapa varieties) seeded acreages (Hartman 2005).

In 1996, conventional canola accounted for $94 \%$ of total seeded canola acres (Figure 7). Two years later (1998), it accounted for only $41 \%$, whereas by 2003 it accounted for only $10 \%$ of seeded acres. Glyphosate tolerant (Roundup Ready), glufosinate tolerant (Liberty Link) and imidazolinone tolerant (Clearfield) made up the rest. Total canola acreage harvested in Alberta fluctuates from year to year, from $2.5 \mathrm{M}$ acres to $4.5 \mathrm{M}$ acres (Table 16).

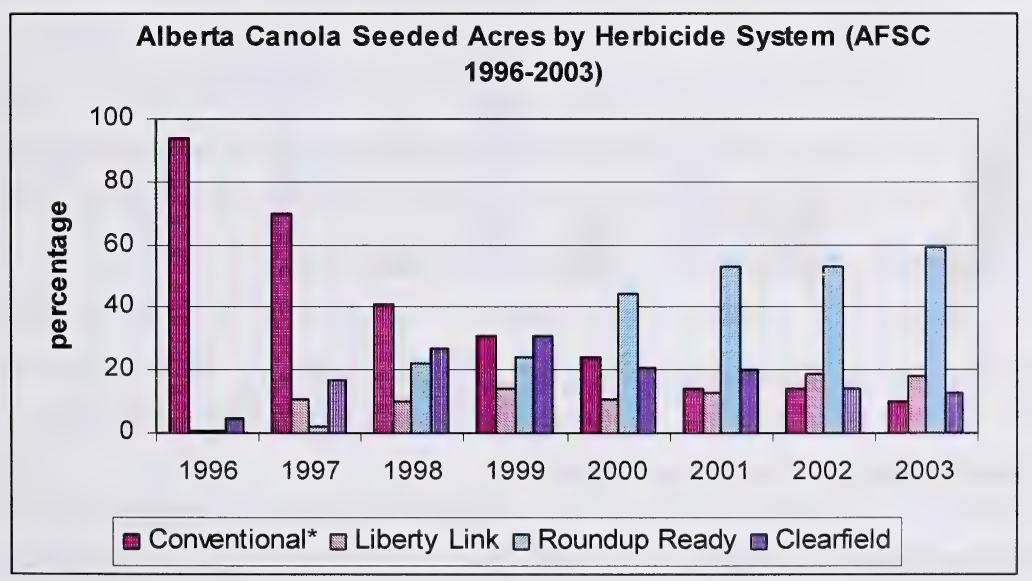

Figure 7. Alberta Canola Seeded Acres (1996-2003)

Table 16. Canola total acres harvested ('000's)(based on Canola Council 2005 data)

\begin{tabular}{|l|l|l|l|l|l|l|l|l|}
\hline & $\mathbf{1 9 9 6}$ & $\mathbf{1 9 9 7}$ & $\mathbf{1 9 9 8}$ & $\mathbf{1 9 9 9}$ & $\mathbf{2 0 0 0}$ & $\mathbf{2 0 0 1}$ & $\mathbf{2 0 0 2}$ & $\mathbf{2 0 0 3}$ \\
\hline $\begin{array}{l}\text { Acres harvested } \\
\text { ('000 acres) }\end{array}$ & 3000 & 3950 & 4300 & 4520 & 3700 & 2670 & 2500 & 3300 \\
\hline
\end{tabular}


Agricultural pesticide sales data reflect the changes in products used on herbicide tolerant canola (Figure 8). The Imidazolinones used on canola (e.g., imazamox and imazethapyr) was a relatively new product family in 1998 , but sales had dropped by 2003 , due to a reduction in Clearfield variety popularity and issues with residue carryover. Pre-emergent herbicides used primarily on canola, but also on other crops (i.e., triallate, ethalfluralin and trifluralin) have dropped significantly in sales volume over the past 15 years, while glyphosate has increased significantly each reporting period. All of the increase in glyphosate sales cannot be directly attributed to changes in canola cropping practices, as glyphosate sales were already increasing in 1993 before herbicide tolerant canola came onto the market. As producers adopted zero-tillage practices throughout the 1990's and early 2000's, the use of glyphosate for pre-seeding weed control instead of tillage has contributed to the increase in glyphosate sales. Additionally, some of the increase in glyphosate use can be attributed to other changes in farming practices such as 'chemical fallow', pre-harvest glyphosate applications, and applications after harvest.

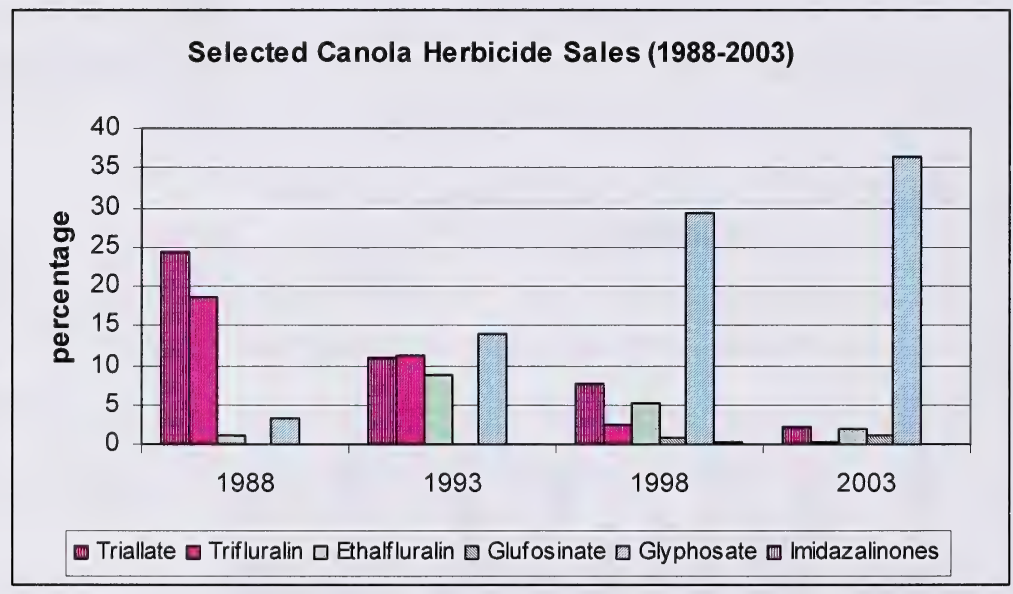

Figure 8. Selected Canola Herbicide Sales (1988-2003)

\subsection{Agricultural Insecticides}

Agricultural insecticide use fluctuates considerably from year to year. In 2003, insecticides accounted for $4.5 \%$ of all agricultural use, and three-quarters of that consisted of two compounds: chlorpyrifos and carbaryl. Most of that usage was related to grasshopper spraying, as there was a considerable grasshopper outbreak that year. Over 3.7 M acres were sprayed in 2003 (based upon data from a financial assistance program by Alberta Agriculture and Food - Ball 2006). For comparison, approximately 663,000 acres were sprayed in 2005 . 
In 1998, high sales volumes of chlorpyrifos were also reported because of an outbreak of Lygus bug which required spraying of $1.4 \mathrm{M}$ acres for this pest species (Byrtus 2000). Insecticide use in both years surveyed was influenced considerably by insect pest outbreaks.

\subsection{Spatial Data}

The pesticide sales data was sorted in a number of ways to provide some spatial perspective. The spatial sorts were done by municipality, by natural region. The municipality level was the highest level of resolution attempted, with over 60 polygons involved. Problems in interpreting data at this scale are that vendors are not evenly distributed amongst municipalities, with some major distribution centres (e.g., Lethbridge, Medicine Hat) influencing some of the spatial interpretation of the data.

\subsubsection{Linkage to Surface Water Monitoring Programs}

The original reason for reporting on pesticide sales was to document product use in Alberta to assist in establishing priorities for monitoring - by product and by area (Cotton and Byrtus 1995). Data from 1993, 1998 and this report have been used to assist in determining priorities for water quality guideline assessment, refine the list of compounds to be monitored, and relate observed detections directly to provincial and basin usage. For example, data from 1998 was used to assist in interpreting detections of pesticides in Alberta surface waters from 1995 to 2002 (Anderson 2005). Integrating monitoring and sales information can also assist in determining whether monitoring efforts in individual basins are in sync with relative pesticide sales. For example, a review of the sampling intensity by basin from 1995 to 2002 shows a reasonably close comparison to current pesticide sales for some basins, however the sampling intensity should be reviewed for a small number of basins (Table 17).

The data in the table shows that most basins are relatively close in sampling intensity and relative pesticide sales. The South Saskatchewan River basin is under represented, and the monitoring network could be reviewed. However, many of the surface water monitoring programs in Alberta are focused on nutrients or other water chemistry parameters of interest in that basin, and pesticides are included as part of the package of analysis, but not necessarily the focus of the program. 
Table 17. Comparison of 1995-2002 pesticide sampling intensity by basin, and 2003 agricultural pesticide sales by basin.

\begin{tabular}{|l|c|c|c|c|c|}
\hline Basin & $\begin{array}{l}\text { No. of } \\
\text { Sites }\end{array}$ & $\begin{array}{l}\text { Total No. of } \\
\text { Samples } \\
\text { Collected }\end{array}$ & $\begin{array}{l}\text { Percentage } \\
\text { Distribution of } \\
\text { Pesticide Samples } \\
\text { Collected by Basin }\end{array}$ & $\begin{array}{l}\text { \% of 2003 Ag } \\
\text { Pesticide Sales }\end{array}$ & $\begin{array}{l}\text { Pesticide } \\
\text { Detection } \\
\text { Frequency by } \\
\text { Basin }\end{array}$ \\
\hline Hay & 1 & 12 & 0.4 & -- & 0 \\
\hline Slave & 1 & 10 & 0.3 & -- & 10.0 \\
\hline Peace & 17 & 262 & 8.6 & 9.7 & 38.5 \\
\hline Athabasca & 20 & 223 & 7.3 & 3.1 & 25.4 \\
\hline Beaver & 12 & 20 & 0.7 & 0.9 & 36.4 \\
\hline North Sask. & 78 & 515 & 16.9 & 15.0 & 63.6 \\
\hline Battle & 36 & 188 & 6.2 & 14.6 & 78.6 \\
\hline Red Deer & 49 & 552 & 18.1 & 17.6 & 73.1 \\
\hline Sounding Creek & 2 & 15 & 0.5 & 1.5 & 77.7 \\
\hline Bow & 30 & 406 & 13.3 & 7.1 & 68.4 \\
\hline Oldman & 74 & 781 & 25.6 & 21.4 & 77.7 \\
\hline South Sask. & 3 & 65 & 2.1 & 8.6 & 81.7 \\
\hline Milk & 4 & 6 & 0.2 & 0.5 & 66.7 \\
\hline Totals & 326 & 3055 & & & 65 \\
\hline
\end{tabular}




\subsection{CONCLUSIONS}

This overview of pesticide sales data collected for 2003 provides a general background for assessing pesticide management programs and pesticide monitoring programs. Product breakdowns and regional distributions are comparable to results observed in 1998, although increasing utilization of glyphosate was observed.

Key results of the 2003 survey are:

- Total sales volume was just over 9.2 million $\mathrm{kg}$ of active ingredient.

- Herbicides and plant growth regulators made up $77.3 \%$ of the total volume sold.

- Of the chemical groups, the Phosphonic/Phosphinic Acid group had the highest sales, comprising $38.1 \%$ of total pesticide sales.

- The Agriculture sector accounted for $96.2 \%$ of all pesticides sold in Alberta, with $78 \%$ of that being herbicides, and $4.5 \%$ being insecticides. The insecticide sales volume was relatively high for Alberta, as 2003 was an outbreak year for grasshoppers.

- The Domestic sector accounted for $0.6 \%$ of total pesticide sales, with herbicides making up $60.1 \%$ and insecticides $35.2 \%$.

- Spatially, the Oldman, Red Deer, North Saskatchewan and Battle River basins each had over 1 million $\mathrm{kg}$ ai of pesticide sales.

- The Central Parkland natural region had the largest volume of sales by natural region, at just over 3 million kg ai.

- Average agricultural pesticide use intensity for Alberta was estimated at $0.78 \mathrm{~kg}$ ai/ha. 


\subsection{REFERENCES}

AAFRD. 2002. 2001 Census of Agriculture for Alberta. I.D., M.D., and County Data by Region. Alberta Agriculture, Food and Rural Development, Statistics and Data Development, Agdex 852-1. Edmonton. 153 pp.

AAFRD. 2003a. Crop Protection 2003. Agdex 606-1. Alberta Agriculture, Food and Rural Development. Crop Diversification Division. Edmonton. 516 pp.

AAFRD. 2003b. Canada-Alberta Environmentally Sustainable Agriculture Agreement (CAESA): Soil Inventory Project Procedures Manual - Data Dictionary. Alberta Agriculture, Food and Rural Development. Published online February 2003 (www1.agric.gov.ab.ca)

Anderson, A-M. 2005. Overview of Pesticide Data in Alberta Surface Waters Since 1995. Alberta Environment, Monitoring and Evaluation Branch, Edmonton. $172 \mathrm{pp}$.

Ball, S. 2006. Alberta Agriculture and Food, Program Compliance Unit, personal communication.

Brimble, S., P. Bacchus and P.-Y. Caux. 2005. Pesticide Utilization in Canada: A Compilation of Current Sales and Use Data. Environment Canada. Ottawa. 144 pp.

Byrtus, G. 2000. Overview of 1998 Pesticide Sales in Alberta. Alberta Environment. Edmonton. $58 \mathrm{pp}$.

Canola Council of Canada. 2005. Canadian Canola Industry-Market Statistics - Dec 14, 2005. www.canola-council.org

Cotton, M.M. and G. Byrtus. 1995. Pesticide Sales Trends in Alberta. Appendix A2. 66 pp in Cross, P. et al. Phase 2. Selection of Soil Landscape Units and Study Design Considerations for the Surface Water Quality Monitoring Program. Prepared for CAESA Water Quality Monitoring Committee. Edmonton.

CAESA. 1998. Agricultural Impact on Water Quality in Alberta: An Initial Assessment. Prepared for Canada-Alberta Environmentally sustainable Agriculture Water Quality Committee. Alberta Agriculture, Food and Rural Development. Lethbridge. 95 pp.

Ecological Stratification Working Group. 1995. A National Ecological Framework for Canada. Agriculture and Agri-Food Canada, Research Branch, Centre for Land and Biological Resources Research and Environment Canada, State of the Environment Directorate, Ecozone Analysis Branch, Ottawa/Hull. 121 pp report and national map at 1:7 500000 scale.

EPA. 2004. Pesticides Industry Sales and Usage. 2000 and 2001 Market Estimates. United States Environmental Protection Agency. Office of Pesticide Programs. Report 733-R-04-001. Washington, D.C. 33 pp.

Gregoire, F. 1997. Overview of 1995 Pesticide Sales in Quebec. Quebec Department of Environment and Wildlife, Pesticides Division. 19 pp. 
Gorse, I. 1999. Bilan des ventes de pesticides au Quebec en 1997. Directions des politiques du secteur agricole, Division des pesticides. Ministere de L'Environnement du Quebec, Envirodoq EN950037, PES-14, 116 pp.

Hartmann, M. 2005. Alberta Agriculture and Food. Personal communication.

Martin, F.R.J. 2001. Addendum \#8 to Hydrology Report \#104. The Determination of Gross and Effective Drainage Areas in the Prairie Provinces. Agriculture and Agri-Food Canada, PFRA, Regina. 109 pp.

Pekalski, B. 1995. A Historical Series of Agricultural Statistics for Alberta: Selected Statistics from the Census of Agriculture. Alberta Agriculture, Food and Rural Development, Market Analysis and Statistics Branch. Edmonton, AB 33 pp.

Strong, W.L. and J.M. Thompson. 1995. Ecodistricts of Alberta: Summary of Biophysical Attributes. Prepared for Alberta Environmental Protection, Edmonton. 92 pp. + maps.

Environment Canada. 2005. Water Survey of Canada - Water Data Products and Services; National Climate Data and Information Archive - Climate Normals and Averages. (www.wsc.ec.gc.ca) 
Appendix 1. Chemical Groups and Active Ingredients

\begin{tabular}{|c|c|c|}
\hline $\begin{array}{l}\text { CHEMICAL } \\
\text { GROUP }\end{array}$ & ACTIVE INGREDIENT NAME & TYPE OF USE \\
\hline \multirow[t]{10}{*}{ Alcohols } & 1,2-ETHANEDIOL & Adjuvant \\
\hline & ABAMECTIN & Insecticide \\
\hline & BRONOPOL & Preservative \\
\hline & BUTOXYPOLYPROPYLENE GLYCOL & Insecticide \\
\hline & CHOLECALCIFEROL & Vertebrate \\
\hline & ERGOCALCIFEROL & Vertebrate \\
\hline & NONYLPHENOXYPOLYETHOXYETHANOL & Adjuvant \\
\hline & OCTYLPHENOXYPOLYETHOXYETHANOL & Adjuvant \\
\hline & $\begin{array}{l}\text { OCTYLPHENOXYPOLYETHOXYETHANOL PHOSPHATE } \\
\text { ESTER }\end{array}$ & Adjuvant \\
\hline & SILOXYLATED POLYETHER & Adjuvant \\
\hline \multirow[t]{10}{*}{ Amides, Anilines } & DEET & Insecticide \\
\hline & FENHEXAMID & Fungicide \\
\hline & MEFENOXAM & Fungicide \\
\hline & METALAXYL & Fungicide \\
\hline & METOLACHLOR & Herbicide \\
\hline & NAPROPAMIDE & Herbicide \\
\hline & PROPANIL & Herbicide \\
\hline & PROPYZAMIDE & Herbicide \\
\hline & S-METOLACHLOR & Herbicide \\
\hline & TEBUFENOZIDE & Insecticide \\
\hline \multirow[t]{6}{*}{ Amino Acids } & FLAMPROP-M-METHYL & Herbicide \\
\hline & HYDRAMETHYLNON & Insecticide \\
\hline & IMIDACLOPRID & Insecticide \\
\hline & STREPTOMYCES GRISEOVIRIDIS & Fungicide \\
\hline & STREPTOMYCIN & Fungicide \\
\hline & THIAMETHOXAM & Insecticide \\
\hline \multirow[t]{6}{*}{$\begin{array}{l}\text { Ammoniums, } \\
\text { Quaternary }\end{array}$} & CHLORMEQUAT & $\begin{array}{l}\text { Plant Growth } \\
\text { Regulator }\end{array}$ \\
\hline & DIDECYL DIMETHYL AMMONIUM CHLORIDE & Disinfectant \\
\hline & DIFENZOQUAT & Herbicide \\
\hline & DIQUAT & Herbicide \\
\hline & N-ALKYL DIMETHYL BENZYL AMMONIUM CHLORIDE & Disinfectant \\
\hline & PARAQUAT & Herbicide \\
\hline \multirow{7}{*}{$\begin{array}{l}\text { Aryloxyphenoxyl } \\
\text { Acids }\end{array}$} & CLODINAFOP-PROPARGYL & Herbicide \\
\hline & DICLOFOP-METHYL & Herbicide \\
\hline & FENOXAPROP-ETHYL & Herbicide \\
\hline & FENOXAPROP-P-ETHYL & Herbicide \\
\hline & FLUAZIFOP-P-BUTYL & Herbicide \\
\hline & QUIZALOFOP-ETHYL & Herbicide \\
\hline & QUIZALOFOP-P-ETHYL & Herbicide \\
\hline \multirow{2}{*}{$\begin{array}{l}\text { Azoles, Diazoles, } \\
\text { Oxazoles, }\end{array}$} & AMITROLE & Herbicide \\
\hline & BENTAZON & Herbicide \\
\hline
\end{tabular}




\begin{tabular}{|c|c|c|}
\hline $\begin{array}{l}\text { CHEMICAL } \\
\text { GROUP }\end{array}$ & ACTIVE INGREDIENT NAME & TYPE OF USE \\
\hline \multirow[t]{12}{*}{ Thiazoles, Triazoles } & DIFENOCONAZOLE & Fungicide \\
\hline & ETRIDIAZOLE & Fungicide \\
\hline & FLORASULAM & Herbicide \\
\hline & FLUCARBAZONE SODIUM & Herbicide \\
\hline & MYCLOBUTANIL & Fungicide \\
\hline & OXADIAZON & Herbicide \\
\hline & PACLOBUTRAZOL & $\begin{array}{l}\text { Plant Growth } \\
\text { Regulator }\end{array}$ \\
\hline & PROPICONAZOLE & Fungicide \\
\hline & STRYCHNINE & Vertebrate \\
\hline & TEBUCONAZOLE & Fungicide \\
\hline & TRIADIMENOL & Fungicide \\
\hline & TRITICONAZOLE & Fungicide \\
\hline \multirow{2}{*}{$\begin{array}{l}\text { Bacillus } \\
\text { thuringiensis species }\end{array}$} & BACILLUS THURINGIENSIS SSP KURSTAKI & Insecticide \\
\hline & BACILLUS THURINGIENSIS SSP ISRAELENSIS & Insecticide \\
\hline \multirow{4}{*}{$\begin{array}{l}\text { Benzimadazoles, } \\
\text { Phenylpyrroles }\end{array}$} & BENOMYL & Fungicide \\
\hline & FLUDIOXONIL & Fungicide \\
\hline & THIABENDAZOLE & Fungicide \\
\hline & THIOPHANATE-METHYL & Fungicide \\
\hline \multirow{3}{*}{$\begin{array}{l}\text { Benzonitriles, } \\
\text { Nitriles }\end{array}$} & BROMOXYNIL & Herbicide \\
\hline & CHLOROTHALONIL & Fungicide \\
\hline & DICHLOBENIL & Herbicide \\
\hline \multirow[t]{10}{*}{ Carbamates } & BENDIOCARB & Insecticide \\
\hline & CARBARYL & Insecticide \\
\hline & CARBOFURAN & Insecticide \\
\hline & CHLORPROPHAM & Herbicide \\
\hline & METHIOCARB & Insecticide \\
\hline & METHOMYL & Insecticide \\
\hline & OXAMYL & Insecticide \\
\hline & PIRIMICARB & Insecticide \\
\hline & PROPAMOCARB HYDROCHLORIDE & Fungicide \\
\hline & PROPOXUR & Insecticide \\
\hline \multirow[t]{11}{*}{ Carboxylic Acids } & CLOPYRALID & Herbicide \\
\hline & DICAMBA & Herbicide \\
\hline & IMAZAMETHABENZ & Herbicide \\
\hline & IMAZAMOX & Herbicide \\
\hline & IMAZETHAPYR & Herbicide \\
\hline & IMAZYPYR & Herbicide \\
\hline & METHYL ANTHRANILATE & Vertebrate \\
\hline & OXINE BENZOATE & Fungicide \\
\hline & $\begin{array}{l}\text { PICLORAM (ACID, ISOOCTYL ESTERS, POTASSIUM } \\
\text { SALT OR AMINE SALTS) }\end{array}$ & Herbicide \\
\hline & TRICLOPYR & Herbicide \\
\hline & TRINEXAPAC-ETHYL & $\begin{array}{l}\text { Plant Growth } \\
\text { Regulator }\end{array}$ \\
\hline
\end{tabular}




\begin{tabular}{|c|c|c|}
\hline $\begin{array}{l}\text { CHEMICAL } \\
\text { GROUP }\end{array}$ & ACTIVE INGREDIENT NAME & TYPE OF USE \\
\hline \multirow[t]{4}{*}{ Chromenones } & BRODIFACOUM & Vertebrate \\
\hline & BROMADIOLONE & Vertebrate \\
\hline & ROTENONE & Insecticide \\
\hline & WARFARIN & Vertebrate \\
\hline \multirow{3}{*}{$\begin{array}{l}\text { Cyclohexanedione } \\
\text { oximes }\end{array}$} & CLETHODIM & Herbicide \\
\hline & SETHOXYDIM & Herbicide \\
\hline & TRALKOXYDIM & Herbicide \\
\hline \multirow{13}{*}{\begin{tabular}{|l|} 
Diazines, \\
Quinoxalines, \\
Morpholines
\end{tabular}} & 6-BENZYLAMINOPURINE & $\begin{array}{l}\text { Plant Growth } \\
\text { Regulator }\end{array}$ \\
\hline & ANCYMIDOL & $\begin{array}{l}\text { Plant Growth } \\
\text { Regulator }\end{array}$ \\
\hline & AZOXYSTROBIN & Fungicide \\
\hline & DIMETHOMORPH & Fungicide \\
\hline & DODEMORPH-ACETATE & Fungicide \\
\hline & MALEIC HYDRAZIDE & $\begin{array}{l}\text { Plant Growth } \\
\text { Regulator }\end{array}$ \\
\hline & PYRACLOSTROBIN & Fungicide \\
\hline & PYRAZON & Herbicide \\
\hline & PYRIDABEN & Insecticide \\
\hline & PYRIDATE & Herbicide \\
\hline & QUINCLORAC & Herbicide \\
\hline & SULFAQUINOXALINE & Vertebrate \\
\hline & TRIFORINE & Fungicide \\
\hline \multirow{4}{*}{$\begin{array}{l}\text { Dicarboximides, } \\
\text { Oxathiin }\end{array}$} & CARBATHIIN & Fungicide \\
\hline & IPRODIONE & Fungicide \\
\hline & OXYCARBOXIN & Fungicide \\
\hline & VINCLOZOLIN & Fungicide \\
\hline \multirow[t]{10}{*}{ Dithiocarbamates } & DAZOMET & Fumigant \\
\hline & DESMEDIPHAM & Herbicide \\
\hline & FERBAM & Fungicide \\
\hline & MANCOZEB & Fungicide \\
\hline & MANEB & Fungicide \\
\hline & METAM & Fumigant \\
\hline & METIRAM & Fungicide \\
\hline & PHENMEDIPHAM & Herbicide \\
\hline & THIRAM & Fungicide \\
\hline & ZINEB & Fungicide \\
\hline \multirow[t]{6}{*}{ Fatty Acids } & FATTY ACID & Herbicide \\
\hline & SAFER'S INSECTICIDAL SOAP & Insecticide \\
\hline & SOAP & Insecticide \\
\hline & SOAP (HERBICIDAL) & Herbicide \\
\hline & TALL OIL FATTY ACIDS & Adjuvant \\
\hline & TALLOW FATTY ACID AMINE ETHOXYLATE & Adjuvant \\
\hline \multirow[t]{2}{*}{ Hydrocarbons } & ASPHALT SOLIDS & Fungicide \\
\hline & MUSCALURE & Insecticide \\
\hline
\end{tabular}




\begin{tabular}{|c|c|c|}
\hline CHEMICAL & ACTIVE INGREDIENT NAME & TYPE OF USE \\
\hline & NAPHTHALENE & Insecticide \\
\hline & PETROLEUM HYDROCARBON BLEND & Adjuvant \\
\hline & POLYMERIZED BUTENES & Vertebrate \\
\hline \multirow[t]{3}{*}{ Indanediones } & CHLOROPHACINONE & Vertebrate \\
\hline & DIFETHIALONE & Vertebrate \\
\hline & DIPHACINONE & Vertebrate \\
\hline \multirow[t]{5}{*}{ Inorganic Coppers } & COPPER NAPHTHENATE & Wood Preservative \\
\hline & COPPER OXYCHLORIDE & Fungicide \\
\hline & COPPER SULPHATE & Fungicide \\
\hline & CUPRIC HYDROXIDE & Fungicide \\
\hline & TRIBASIC COPPER SULPHATE & Fungicide \\
\hline \multirow[t]{2}{*}{ Inorganic Zincs } & ZINC NAPHTHENATE & Wood Preservative \\
\hline & ZINC PHOSPHIDE & Vertebrate \\
\hline \multirow[t]{17}{*}{ Inorganics, Other } & ALUMINUM PHOSPHIDE & Insecticide \\
\hline & AMMONIA & Vertebrate \\
\hline & AMMONIUM SULPHATE & Adjuvant \\
\hline & BORACIC ACID & Insecticide \\
\hline & BORAX & Insecticide \\
\hline & FERRIC PHOSPHATE & Insecticide \\
\hline & FERROUS SULFATE & Herbicide \\
\hline & HYDROGEN PEROXIDE & Insecticide \\
\hline & LIME SULPHUR OR CALCIUM POLYSULPHIDE & Fungicide \\
\hline & POTASSIUM MONOPERSULPHATE & Disinfectant \\
\hline & SILICA AEROGEL & Insecticide \\
\hline & SILICON DIOXIDE SALT WATER FOSSILS & Insecticide \\
\hline & SODIUM CHLORATE & Herbicide \\
\hline & SODIUM METABORATE TETRAHYDRATE & Herbicide \\
\hline & SULPHUR (FUNGICIDE) & Fungicide \\
\hline & SULPHUR (INSECTICIDE) & Insecticide \\
\hline & SULPHUR (VERTEBRATE CONTROL) & Vertebrate \\
\hline \multirow{15}{*}{$\begin{array}{l}\text { Miscellaneous } \\
\text { (Non-classified) }\end{array}$} & ACETIC ACID & Herbicide \\
\hline & ACROLEIN & Herbicide \\
\hline & ETHOFUMESATE & Herbicide \\
\hline & FORMALDEHYDE & Fungicide \\
\hline & KINOPRENE & Insecticide \\
\hline & METALDEHYDE & Insecticide \\
\hline & METHOPRENE & Insecticide \\
\hline & METHYL NONYL KETONE & Vertebrate \\
\hline & MUSTARD SEED POWDER (BRASSICA HIRTA) & Vertebrate \\
\hline & N-ALKYL DIETHANOLAMINE & Adjuvant \\
\hline & N-ALKYL POLYETHOXYETHANOL & Adjuvant \\
\hline & NATURAL GUM RESINS & Insecticide \\
\hline & PARAFORMALDEHYDE & Disinfectant \\
\hline & PIPERONYL BUTOXIDE & Insecticide \\
\hline & POLYOXYALKYLATED ALKYL PHOSPHATE ESTER & Adjuvant \\
\hline
\end{tabular}




\begin{tabular}{|c|c|c|}
\hline $\begin{array}{l}\text { CHEMICAL } \\
\text { GROUP }\end{array}$ & ACTIVE INGREDIENT NAME & TYPE OF USE \\
\hline & PYMETROZINE & Insecticide \\
\hline & SODIUM ALPHA-OLEFIN SULFONATE & Vertebrate \\
\hline & SPINOSAD FACTOR A PLUS & Insecticide \\
\hline & WATER SOLUBLE DYES & Herbicide \\
\hline \multirow[t]{4}{*}{ Nitro Derivatives } & ETHALFLURALIN & Herbicide \\
\hline & OXYFLUORFEN & Herbicide \\
\hline & PENDIMETHALIN & Herbicide \\
\hline & TRIFLURALIN & Herbicide \\
\hline \multirow{8}{*}{$\begin{array}{l}\text { Oils, Mineral and } \\
\text { Vegetable }\end{array}$} & MINERAL OIL (INSECTICIDAL OR ADJUVANT) & Insecticide \\
\hline & OIL OF BLACK PEPPER & Vertebrate \\
\hline & OLEORESIN CAPSICUM (CAPSAICIN) & Vertebrate \\
\hline & PARAFFIN BASE MINERAL OIL (ADJUVANT) & Adjuvant \\
\hline & PARAFFIN BASE PETROLEUM OIL & Adjuvant \\
\hline & PIPERINE & Vertebrate \\
\hline & P-MENTHANE-3, 8-DIOL & Insecticide \\
\hline & SURFACTANT BLEND & Adjuvant \\
\hline \multirow[t]{2}{*}{ Organic Acids } & DAMINOZIDE & $\begin{array}{l}\text { Plant Growth } \\
\text { Regulator }\end{array}$ \\
\hline & GIBBERELLIC ACID & $\begin{array}{l}\text { Plant Growth } \\
\text { Regulator }\end{array}$ \\
\hline \multirow[t]{7}{*}{ Organochlorines } & CHLORONEB & Fungicide \\
\hline & DICOFOL & Insecticide \\
\hline & ENDOSULFAN & Insecticide \\
\hline & LINDANE & Insecticide \\
\hline & METHOXYCHLOR & Insecticide \\
\hline & PARADICHLOROBENZENE & Insecticide \\
\hline & QUINTOZENE & Fungicide \\
\hline \multirow[t]{2}{*}{ Organometallics } & 10,10'-OXYBIS(PHENOXARSINE) & Preservative \\
\hline & FENBUTATIN OXIDE & Insecticide \\
\hline \multirow[t]{16}{*}{ Organophosphorous } & ACEPHATE & Insecticide \\
\hline & AZINPHOS-METHYL & Insecticide \\
\hline & BENSULIDE & Herbicide \\
\hline & CHLORPYRIFOS & Insecticide \\
\hline & COUMAPHOS & Insecticide \\
\hline & DIAZINON & Insecticide \\
\hline & DICHLORVOS & Insecticide \\
\hline & DIMETHOATE & Insecticide \\
\hline & \begin{tabular}{|l|} 
FENTHION \\
\end{tabular} & Insecticide \\
\hline & FOSETYL-AL & Fungicide \\
\hline & MALATHION & Insecticide \\
\hline & METHAMIDOPHOS & Insecticide \\
\hline & NALED & Insecticide \\
\hline & PHORATE & Insecticide \\
\hline & PHOSALONE & Insecticide \\
\hline & \begin{tabular}{|l} 
PHOSMET \\
\end{tabular} & Insecticide \\
\hline
\end{tabular}




\begin{tabular}{|c|c|c|}
\hline CHEMICAL & ACTIVE INGREDIENT NAME & TYPE OF USE \\
\hline & PROPETAMPHOS & Insecticide \\
\hline & TERBUFOS & Insecticide \\
\hline Phenols & CREOSOTE & Wood Preservative \\
\hline \multirow[t]{6}{*}{ Phenoxy Acids } & 2,4-D (ACID, AMINE SALTS, OR LOW VOLATILE ESTERS) & Herbicide \\
\hline & 2,4-DB (MIXED BUTYL ESTERS OR ISOOCTYL ESTERS) & Herbicide \\
\hline & DICHLORPROP & Herbicide \\
\hline & $\begin{array}{l}\text { MCPA (ACID, AMINE SALTS, ESTERS, POTASSIUM } \\
\text { SALTS OR SODIUM SALTS) }\end{array}$ & Herbicide \\
\hline & MCPB PRESENT AS SODIUM SALT & Herbicide \\
\hline & $\begin{array}{l}\text { MECOPROP (D-ISOMER) PRESENT AS ACID, AMINE } \\
\text { SALTS OR POTASSIUM SALTS) }\end{array}$ & Herbicide \\
\hline \multirow[t]{4}{*}{$\begin{array}{l}\text { Phosphonic Acids, } \\
\text { Phosphinic Acids }\end{array}$} & ETHEPHON & $\begin{array}{l}\text { Plant Growth } \\
\text { Regulator }\end{array}$ \\
\hline & GLUFOSINATE AMMONIUM & Herbicide \\
\hline & $\begin{array}{l}\text { GLYPHOSATE (ACID, ISOPROPYLAMINE SALT, MONO- } \\
\text { AMMONIUM SALT OR TRIMETHYLSULFONIUM SALT) } \\
\end{array}$ & Herbicide \\
\hline & TRICHLORFON & Insecticide \\
\hline \multirow[t]{4}{*}{ Phthalic Acids } & CAPTAN & Fungicide \\
\hline & ENDOTHALL & Herbicide \\
\hline & FOLPET & Fungicide \\
\hline & N-OCTYL BICYCLOHEPTENE DICARBOXIMIDE & Insecticide \\
\hline \multirow{13}{*}{$\begin{array}{l}\text { Pyrethroids, } \\
\text { Pyrethrins }\end{array}$} & ALLETHRIN & Insecticide \\
\hline & CYFLUTHRIN & Insecticide \\
\hline & CYHALOTHRIN-LAMBDA & Insecticide \\
\hline & CYPERMETHRIN & Insecticide \\
\hline & D-CIS, TRANS ALLETHRIN & Insecticide \\
\hline & DELTAMETHRIN & Insecticide \\
\hline & D-PHENOTHRIN & Insecticide \\
\hline & D-TRANS ALLETHRIN & Insecticide \\
\hline & FENVALERATE & Insecticide \\
\hline & PERMETHRIN & Insecticide \\
\hline & PYRETHRINS & Insecticide \\
\hline & RESMETHRIN & Insecticide \\
\hline & TETRAMETHRIN & Insecticide \\
\hline \multirow[t]{5}{*}{ Pyridines } & 4-AMINOPYRIDINE & Vertebrate \\
\hline & DI-N-PROPYL ISOCINCHOMERONATE & Insecticide \\
\hline & DITHIOPYR & Herbicide \\
\hline & \begin{tabular}{|l|l|} 
FLUROXYPYR \\
\end{tabular} & Herbicide \\
\hline & NICOTINE & Insecticide \\
\hline \multirow{6}{*}{$\begin{array}{l}\text { Sulfonylureas, } \\
\text { Uracils }\end{array}$} & BROMACIL & Herbicide \\
\hline & CHLORSULFURON & Herbicide \\
\hline & ETHAMETSULFURON-METHYL & Herbicide \\
\hline & METSULFURON-METHYL & Herbicide \\
\hline & NICOSULFURON & Herbicide \\
\hline & RIMSULFURON & Herbicide \\
\hline
\end{tabular}




\begin{tabular}{|c|c|c|}
\hline $\begin{array}{l}\text { CHEMICAL } \\
\text { GROUP }\end{array}$ & ACTIVE INGREDIENT NAME & TYPE OF USE \\
\hline & SULFOSULFURON & Herbicide \\
\hline & TERBACIL & Herbicide \\
\hline & THIFENSULFURON METHYL & Herbicide \\
\hline & TRIASULFURON & Herbicide \\
\hline & TRIBENURON METHYL & Herbicide \\
\hline & TRIFLUSULFURON METHYL & Herbicide \\
\hline \multirow[t]{3}{*}{ Thiocarbamates } & CYCLOATE & Herbicide \\
\hline & EPTC & Herbicide \\
\hline & TRIALLATE & Herbicide \\
\hline \multirow{7}{*}{$\begin{array}{l}\text { Triazines, } \\
\text { Triazinones, } \\
\text { Tetrazines }\end{array}$} & ATRAZINE & Herbicide \\
\hline & CYANAZINE & Herbicide \\
\hline & CYROMAZINE & Insecticide \\
\hline & HEXAZINONE & Herbicide \\
\hline & METRIBUZIN & Herbicide \\
\hline & PROMETRYNE & Herbicide \\
\hline & SIMAZINE & Herbicide \\
\hline \multirow[t]{5}{*}{ Urea Derivatives } & 1-BROMO-3-CHLORO-5,5-DIMETHYLHYDANTOIN & Anti-microbial \\
\hline & CYMOXANIL & Fungicide \\
\hline & DIFLUBENZURON & Insecticide \\
\hline & DIURON & Herbicide \\
\hline & LINURON & Herbicide \\
\hline
\end{tabular}

Appendix 2. Alberta 2003 Pesticide Sales by Active Ingredient

\begin{tabular}{|l|l|r|r|r|}
\hline ACTIVE INGREDIENT NAME & Type of use & $\begin{array}{l}\mathbf{2 0 0 3} \text { total } \\
(\mathbf{k g} \text { ai) }\end{array}$ & $\begin{array}{l}\mathbf{2 0 0 3} \\
\mathbf{\%}\end{array}$ & $\begin{array}{l}\mathbf{1 9 9 8} \text { total } \\
(\mathbf{k g} \text { ai) }\end{array}$ \\
\hline \hline GLYPHOSATE & Herbicide & 3419822.1 & 36.9 & 2682748.9 \\
\hline MCPA & Herbicide & 1097359.0 & 118 & 885239.1 \\
\hline 2,4-D & Herbicide & 763357.7 & 8.2 & 765820.4 \\
\hline PETROLEUM HYDROCARBON BLEND & Adjuvant & 559728.7 & 6.0 & 368704.3 \\
\hline SURFACTANT BLEND & Adjuvant & 438235.7 & 4.7 & 496561.7 \\
\hline BROMOXYNIL & Herbicide & 354906.6 & 3.8 & 268105.3 \\
\hline CHLORPYRIFOS & Insecticide & 197765.5 & 2.1 & 217397.5 \\
\hline TRIALLATE & Herbicide & 197221.4 & 2.1 & 693178.5 \\
\hline PARAFFIN BASE MINERAL OIL (ADJUVANT) & Adjuvant & 192634.4 & 2.1 & 193162.6 \\
\hline ETHALFLURALIN & Herbicide & 168135.0 & 1.8 & 452294.4 \\
\hline TRALKOXYDIM & Herbicide & 141226.1 & 1.5 & 126323.5 \\
\hline IMAZAMETHABENZ & Herbicide & 138551.4 & 1.5 & 173679.2 \\
\hline DICAMBA & Herbicide & 121422.7 & 1.3 & 138278.6 \\
\hline GLUFOSINATE AMMONIUM & Herbicide & 107255.5 & 1.2 & 63863.8 \\
\hline CARBARYL & Insecticide & 104430.6 & 1.1 & 3142.8 \\
\hline FENOXAPROP-P-ETHYL & Herbicide & 64212.1 & 0.69 & 59919.0 \\
\hline NONYLPHENOXYPOLYETHOXYETHANOL & Adjuvant & 59558.8 & 0.64 & 94247.3 \\
\hline DICHLORPROP & Herbicide & 57450.1 & 0.62 & 40942.4 \\
\hline CLOPYRALID & Herbicide & 56618.0 & 0.61 & 59019.7 \\
\hline
\end{tabular}




\begin{tabular}{|c|c|c|c|c|}
\hline ACTIVE INGREDIENT NAME & Type of use & $\begin{array}{l}2003 \text { total } \\
\text { (kg ai) }\end{array}$ & \begin{tabular}{|l|}
2003 \\
$\%$
\end{tabular} & $\begin{array}{l}1998 \text { total } \\
\text { (kg ai) }\end{array}$ \\
\hline AMMONIUM SULPHATE & Herbicide & 51595.1 & 0.56 & 71104.4 \\
\hline \begin{tabular}{|l} 
CLODINAFOP-PROPARGYL \\
\end{tabular} & Herbicide & 49520.8 & 0.53 & 34408.9 \\
\hline CARBATHIIN & Fungicide & 45228.3 & 0.49 & 122292.0 \\
\hline CHLOROTHALONIL & Fungicide & 43208.6 & 0.47 & 37334.0 \\
\hline FLUROXYPYR & Herbicide & 43166.7 & 0.47 & 23700.8 \\
\hline PHORATE & Insecticide & 41417.3 & 0.45 & 19209.0 \\
\hline TRIFLURALIN & Herbicide & 40654.3 & 0.44 & 230028.2 \\
\hline MANCOZEB & Fungicide & 36127.2 & 0.39 & 45813.9 \\
\hline TRICLOPYR & Herbicide & 33116.2 & 0.36 & 30311.8 \\
\hline DIURON & Herbicide & 31096.3 & 0.34 & 9919.3 \\
\hline SETHOXYDIM & Herbicide & 30993.1 & 0.33 & 58678.5 \\
\hline MEFENOXAM & Fungicide & 29813.1 & 0.32 & \\
\hline PARAFFIN BASE PETROLEUM OIL & Adjuvant & 27958.4 & 0.30 & 77427.2 \\
\hline THIRAM & Fungicide & 27136.3 & 0.29 & 22791.7 \\
\hline MECOPROP-D & Herbicide & 26080.4 & 0.28 & 27264.1 \\
\hline DIQUAT & Herbicide & 25524.4 & 0.28 & 21765.0 \\
\hline FLUDIOXONIL & Fungicide & 24377.7 & 0.26 & \\
\hline VINCLOZOLIN & Fungicide & 24324.3 & 0.26 & 25823.1 \\
\hline BENTAZON & Herbicide & 21986.9 & 0.24 & 12066.2 \\
\hline IPRODIONE & Fungicide & 21014.3 & 0.23 & 9592.7 \\
\hline PICLORAM & Herbicide & 17897.0 & 0.19 & 15109.4 \\
\hline MALATHION & Insecticide & 17413.8 & 0.19 & 22316.5 \\
\hline ACROLEIN & Herbicide & 16981.4 & 0.18 & 17520.5 \\
\hline SILICON DIOXIDE SALT WATER FOSSILS & Insecticide & 15588.2 & 0.17 & 47025.2 \\
\hline POLYOXYALKYLATED ALKYL PHOSPHATE ESTER & Adjuvant & 13727.9 & 0.15 & 9340.0 \\
\hline PROPICONAZOLE & Fungicide & 13183.4 & 0.14 & 5664.4 \\
\hline EPTC & Herbicide & 11944.0 & 0.13 & 38574.2 \\
\hline $2,4-\mathrm{DB}$ & Herbicide & 11501.4 & 0.12 & 20950.3 \\
\hline DIFENOCONAZOLE & Fungicide & 11067.6 & 0.12 & \\
\hline LINURON & Herbicide & 8991.4 & 0.10 & 8754 \\
\hline THIFENSULFURON METHYL & Herbicide & 8572.3 & 0.09 & 13697.5 \\
\hline SILICA AEROGEL & Insecticide & 7785.0 & 0.08 & 11052.5 \\
\hline ETHOFUMESATE & Herbicide & 7742.4 & 0.08 & 12559.4 \\
\hline QUINTOZENE & Fungicide & 7166.5 & 0.08 & 9808.9 \\
\hline CUPRIC HYDROXIDE & Fungicide & 6885.0 & 0.07 & 252.5 \\
\hline METRIBUZIN & Herbicide & 6306.3 & 0.07 & 7601.4 \\
\hline FLORASULAM & Herbicide & 6090.5 & 0.07 & \\
\hline TEBUCONAZOLE & Fungicide & 5922.4 & 0.06 & \\
\hline FLUAZIFOP-P-BUTYL & Herbicide & 5808.5 & 0.06 & 12914.0 \\
\hline TRIBENURON METHYL & Herbicide & 5404.8 & 0.06 & 6763.6 \\
\hline ENDOSULFAN & Insecticide & 5229.7 & 0.05 & 761.1 \\
\hline DIAZINON & Insecticide & 5149.9 & 0.06 & 4087.3 \\
\hline OCTYLPHENOXYPOLYETHOXYETHANOL & Adjuvant & 5144.7 & 0.06 & 9219.0 \\
\hline CYHALOTHRIN-LAMBDA & Insecticide & 5124.4 & 0.06 & 1097.9 \\
\hline IMAZETHAPYR & Herbicide & 5063.2 & 0.05 & 10528.6 \\
\hline
\end{tabular}




\begin{tabular}{|c|c|c|c|c|}
\hline ACTIVE INGREDIENT NAME & Type of use & $\begin{array}{l}2003 \text { total } \\
\text { (kg ai) }\end{array}$ & \begin{tabular}{|l|}
2003 \\
$\%$
\end{tabular} & $\begin{array}{l}1998 \text { total } \\
\text { (kg ai) }\end{array}$ \\
\hline LINDANE & Insecticide & 4779.5 & 0.05 & 56743.7 \\
\hline BROMACIL & Herbicide & 4770.3 & 0.05 & 3106.9 \\
\hline ATRAZINE & Herbicide & 4654.5 & 0.05 & 5753.8 \\
\hline DIFENZOQUAT & Herbicide & 4464.0 & 0.05 & 9585.5 \\
\hline QUIZALOFOP P-ETHYL & Herbicide & 4461.0 & 0.05 & 2669.7 \\
\hline CLETHODIM & Herbicide & 3694.9 & 0.04 & 2490.7 \\
\hline DEET & Insecticide & 3413.3 & 0.04 & 4167.9 \\
\hline MANEB & Fungicide & 3346.4 & 0.04 & 8462.0 \\
\hline S-METOLACHLOR & Herbicide & 3278.9 & 0.04 & \\
\hline BENOMYL & Fungicide & 3275.0 & 0.04 & 14616.3 \\
\hline IMAZAMOX & Herbicide & 3122.0 & 0.03 & 4231.8 \\
\hline SULPHUR (FUNGICIDE) & Fungicide & 2968.1 & 0.03 & 7315.4 \\
\hline TERBUFOS & Insecticide & 2893.0 & 0.03 & 6697.8 \\
\hline DELTAMETHRIN & Insecticide & 2735.1 & 0.03 & 775.1 \\
\hline TRICHLORFON & Insecticide & 2331.3 & 0.03 & 34334.3 \\
\hline FLUCARBAZONE SODIUM & Herbicide & 2292.2 & 0.02 & \\
\hline MINERAL OIL (INSECTICIDAL OR ADJUVANT) & Insecticide & 2233.7 & 0.02 & 3477.4 \\
\hline AMITROLE & Herbicide & 2107.0 & 0.02 & 2026.5 \\
\hline TRITICONAZOLE & Fungicide & 2080.4 & 0.02 & \\
\hline METIRAM & Fungicide & 2068.8 & 0.02 & 14862.4 \\
\hline AZOXYSTROBIN & Fungicide & 1961.1 & 0.02 & \\
\hline MALEIC HYDRAZIDE & Growth Regulator & 1952.7 & 0.02 & 551.7 \\
\hline MCPB & Herbicide & 1717.5 & 0.02 & 3271.5 \\
\hline IMAZYPYR & Herbicide & 1710.0 & 0.02 & 200.6 \\
\hline DIMETHOATE & Insecticide & 1691.1 & 0.02 & 4883.4 \\
\hline FERROUS SULFATE & Herbicide & 1593.4 & 0.02 & 1818.7 \\
\hline PARAQUAT & Herbicide & 1591.6 & 0.02 & 4820.4 \\
\hline ACETIC ACID & Herbicide & 1555.5 & 0.02 & \\
\hline THIABENDAZOLE & Fungicide & 1388.8 & 0.01 & 3187.2 \\
\hline DESMEDIPHAM & Herbicide & 1348.5 & 0.01 & 2334.8 \\
\hline PHENMEDIPHAM & Herbicide & 1348.5 & 0.01 & 2330.3 \\
\hline PYRACLOSTROBIN & Fungicide & 1263.6 & 0.01 & \\
\hline THIAMETHOXAM & Insecticide & 1176.2 & 0.01 & \\
\hline SIMAZINE & Herbicide & 1160.4 & 0.01 & 3688.1 \\
\hline SILOXYLATED POLYETHER & Adjuvant & 1130.9 & 0.01 & \\
\hline SAFER'S INSECTICIDAL SOAP & Insecticide & 1040.2 & 0.01 & 1641.6 \\
\hline METHAMIDOPHOS & Insecticide & 1008.0 & 0.01 & 19.2 \\
\hline HYDROGEN PEROXIDE & Insecticide & 996.8 & 0.01 & \\
\hline IMIDACLOPRID & Insecticide & 978.0 & 0.01 & 9.5 \\
\hline NALED & Insecticide & 972.6 & 0.01 & 1257.9 \\
\hline SOAP & Insecticide & 947.2 & 0.01 & \\
\hline HEXAZINONE & Herbicide & 940.9 & 0.01 & 2428.1 \\
\hline QUINCLORAC & Herbicide & 878.1 & 0.01 & 1459.4 \\
\hline ETHAMETSULFURON-METHYL & Herbicide & 844.4 & 0.01 & 4636.4 \\
\hline PENDIMETHALIN & Herbicide & 782.8 & 0.01 & 1061.1 \\
\hline
\end{tabular}




\begin{tabular}{|c|c|c|c|c|}
\hline ACTIVE INGREDIENT NAME & Type of use & \begin{tabular}{|l|}
2003 total \\
(kg ai)
\end{tabular} & \begin{tabular}{|l|}
2003 \\
$\%$
\end{tabular} & $\begin{array}{l}1998 \text { total } \\
\text { (kg ai) }\end{array}$ \\
\hline DICLOFOP-METHYL & Herbicide & 715.2 & 0.01 & 3239.9 \\
\hline DICHLOBENIL & Herbicide & 684.7 & 0.01 & 728.2 \\
\hline CARBOFURAN & Insecticide & 676.1 & 0.01 & 6413.4 \\
\hline COPPER SULPHATE & Fungicide & 672.1 & 0.01 & 316.1 \\
\hline COPPER OXYCHLORIDE & Fungicide & 649.5 & 0.01 & 220.2 \\
\hline SULFOSULFURON & Herbicide & 596.3 & 0.01 & \\
\hline ASPHALT SOLIDS & Fungicide & 591.9 & 0.01 & 1387.5 \\
\hline PROMETRYNE & Herbicide & 586.3 & 0.01 & \\
\hline MUSTARD SEED POWDER (BRASSICA HIRTA) & Rodenticide & 471.3 & 0.01 & \\
\hline CYCLOATE & Herbicide & 460.8 & 0.00 & 2289.6 \\
\hline THIOPHANATE-METHYL & Fungicide & 454.7 & 0.00 & 859.4 \\
\hline CAPTAN & Insecticide & 439.4 & 0.00 & 286.8 \\
\hline METHOMYL & Insecticide & 436.8 & 0.00 & 434.5 \\
\hline ZINC PHOSPHIDE & Rodenticide & 435.3 & 0.00 & 49.2 \\
\hline FENTHION & Insecticide & 418.8 & 0.00 & 293.6 \\
\hline METAM & Soil fumigant & 415.1 & 0.00 & 410.7 \\
\hline PROPAMOCARB HYDROCHLORIDE & Fungicide & 411.9 & 0.00 & 1271.3 \\
\hline PIPERONYL BUTOXIDE & Insecticide & 405.1 & 0.00 & 591.6 \\
\hline ACEPHATE & Insecticide & 383.6 & 0.00 & 257.6 \\
\hline BUTOXYPOLYPROPYLENE GLYCOL & Insecticide & 370.2 & 0.00 & 2.3 \\
\hline LIME SULPHUR & Fungicide & 364.8 & 0.00 & 224 \\
\hline METSULFURON-METHYL & Herbicide & 360.9 & 0.00 & 938.6 \\
\hline FOSETYL-AL & Fungicide & 351.8 & 0.00 & 166.3 \\
\hline PYRAZON & Herbicide & 338.0 & 0.00 & 1204.9 \\
\hline TERBACIL & Herbicide & 332.8 & 0.00 & 891.2 \\
\hline D-TRANS ALLETHRIN & Insecticide & 320.6 & 0.00 & 20.7 \\
\hline PERMETHRIN & Insecticide & 315.8 & 0.00 & 397.2 \\
\hline AZINPHOS-METHYL & Insecticide & 304.0 & 0.00 & 260.6 \\
\hline METALAXYL & Fungicide & 302.2 & 0.00 & 3796.2 \\
\hline SODIUM ALPHA-OLEFIN SULFONATE & Rodenticide & 299.1 & 0.00 & \\
\hline ALUMINUM PHOSPHIDE & Insecticide & 269.6 & 0.00 & 2215.7 \\
\hline STRYCHNINE & Rodenticide & 244.8 & 0.00 & 163.2 \\
\hline CHLORONEB & Fungicide & 233.9 & 0.00 & 559.3 \\
\hline PYRETHRINS & Insecticide & 220.9 & 0.00 & 178.2 \\
\hline RIMSULFURON & Herbicide & 219.1 & 0.00 & 63.2 \\
\hline DICHLORVOS & Insecticide & 193.5 & 0.00 & 335.2 \\
\hline BRONOPOL & Preservative & 192.1 & 0.00 & \\
\hline TRIASULFURON & Herbicide & 190.3 & 0.00 & 505 \\
\hline SULPHUR (VERTEBRATE CONTROL) & Rodenticide & 185.4 & 0.00 & 1045.3 \\
\hline OXYCARBOXIN & Fungicide & 185.3 & 0.00 & 154.1 \\
\hline PROPYZAMIDE & Herbicide & 179.4 & 0.00 & 272 \\
\hline TALL OIL FATTY ACIDS & Adjuvant & 176.0 & 0.00 & 1470.4 \\
\hline BORAX & Insecticide & 168.2 & 0.00 & 218.8 \\
\hline DIDECYL DIMETHYL AMMONIUM CHLORIDE & Anti-microbial & 167.4 & 0.00 & 120.6 \\
\hline N-ALKYL DIMETHYL BENZYL AMMONIUM CHLORIDE & Disinfectant & 163.4 & 0.00 & 63.7 \\
\hline
\end{tabular}




\begin{tabular}{|c|c|c|c|c|}
\hline ACTIVE INGREDIENT NAME & Type of use & \begin{tabular}{|l|}
2003 total \\
(kg ai)
\end{tabular} & \begin{tabular}{|l|l|l}
2003 & 1 \\
$\%$
\end{tabular} & $\begin{array}{l}1998 \text { total } \\
\text { (kg ai) }\end{array}$ \\
\hline MYCLOBUTANIL & Fungicide & 162.6 & 0.00 & 16.8 \\
\hline PIRIMICARB & Insecticide & 162.2 & 0.00 & 154.1 \\
\hline NAPROPAMIDE & Herbicide & 159.1 & 0.00 & 294.6 \\
\hline PHOSMET & Insecticide & 140.7 & 0.00 & 370 \\
\hline NICOSULFURON & Herbicide & 140.1 & 0.00 & \\
\hline TALLOW FATTY ACID AMINE ETHOXYLATE & Adjuvant & 138.1 & 0.00 & 3272.2 \\
\hline TRIBASIC COPPER SULPHATE & Fungicide & 130.9 & 0.00 & 159.6 \\
\hline ETRIDIAZOLE & Herbicide & 122.1 & 0.00 & 210.6 \\
\hline CHLORPROPHAM & Herbicide & 120.4 & 0.00 & 679.8 \\
\hline TRIADIMENOL & Fungicide & 120.1 & 0.00 & 178 \\
\hline DAMINOZIDE & Growth Regulator & 119.9 & 0.00 & 147.5 \\
\hline NAPHTHALENE & Insecticide & 118.5 & 0.00 & 1371.6 \\
\hline SODIUM METABORATE TETRAHYDRATE & Herbicide & 117.5 & 0.00 & 1616.3 \\
\hline ETHEPHON & Fungicide & 115.2 & 0.00 & 31.2 \\
\hline PROPOXUR & Insecticide & 107.2 & 0.00 & 170 \\
\hline METALDEHYDE & Insecticide & 101.3 & 0.00 & 476.5 \\
\hline ZINEB & Fungicide & 99.5 & 0.00 & 491.7 \\
\hline CHLORSULFURON & Herbicide & 98.6 & 0.00 & 66.7 \\
\hline SULPHUR (INSECTICIDE) & Insecticide & 96.6 & 0.00 & 280.7 \\
\hline PROPANIL & Herbicide & 96.0 & 0.00 & 1616 \\
\hline BENSULIDE & Herbicide & 95.9 & 0.00 & 212.6 \\
\hline FERBAM & Herbicide & 95.1 & 0.00 & 77.6 \\
\hline PYMETROZINE & Insecticide & 95.0 & 0.00 & \\
\hline CYFLUTHRIN & Insecticide & 92.3 & 0.00 & 1.3 \\
\hline CHLORMEQUAT & Growth Regulator & 89.7 & 0.00 & 62.3 \\
\hline FATTY ACID & Growth Regulator & 88.9 & 0.00 & 34.6 \\
\hline DICOFOL & Insecticide & 84.0 & 0.00 & 423.6 \\
\hline TRIFLUSULFURON METHYL & Herbicide & 81.8 & 0.00 & \\
\hline DAZOMET & Soil fumigant & 78.4 & 0.00 & 627.2 \\
\hline PARAFORMALDEHYDE & Disinfectant & 68.3 & 0.00 & \\
\hline CYMOXANIL & Fungicide & 65.9 & 0.00 & \\
\hline ROTENONE & Herbicide & 61.7 & 0.00 & 180.0 \\
\hline $\begin{array}{l}\text { OCTYLPHENOXYPOLYETHOXYETHANOL PHOSPHATE } \\
\text { ESTER }\end{array}$ & Adjuvant & 60.5 & 0.00 & \\
\hline POTASSIUM MONOPERSULPHATE & Disinfectant & 59.9 & 0.00 & 15 \\
\hline COPPER NAPHTHENATE & Anti-microbial & 59.8 & 0.00 & 123.2 \\
\hline CREOSOTE & Anti-microbial & 58.1 & 0.00 & 805.2 \\
\hline FOLPET & Insecticide & 55.4 & 0.00 & 54.8 \\
\hline SODIUM CHLORATE & Herbicide & 53.0 & 0.00 & 729.1 \\
\hline OXINE BENZOATE & Fungicide & 52.5 & 0.00 & 59.1 \\
\hline WATER SOLUBLE DYES & Herbicide & 48.7 & 0.00 & 5.1 \\
\hline OXYFLUORFEN & Herbicide & 46.0 & 0.00 & 27.4 \\
\hline CYANAZINE & Herbicide & 45.0 & 0.00 & 3891.6 \\
\hline TRINEXAPAC-ETHYL & Growth Regulator & 44.8 & 0.00 & \\
\hline QUIZALOFOP-ETHYL & Herbicide & 44.7 & 0.00 & 23101.0 \\
\hline
\end{tabular}




\begin{tabular}{|c|c|c|c|c|}
\hline ACTIVE INGREDIENT NAME & Type of use & $\begin{array}{l}2003 \text { total } \\
\text { (kg ai) }\end{array}$ & $\begin{array}{l}2003 \\
\%\end{array}$ & $\begin{array}{l}1998 \text { total } \\
\text { (kg ai) }\end{array}$ \\
\hline ENDOTHALL & Herbicide & 44.3 & 0.00 & 511.0 \\
\hline DODEMORPH-ACETATE & Fungicide & 42.8 & 0.00 & 55.2 \\
\hline SOAP (HERBICIDAL) & Herbicide & 42.4 & 0.00 & 1221.5 \\
\hline BORACIC ACID & Insecticide & 41.6 & 0.00 & 322.7 \\
\hline BENDIOCARB & Insecticide & 36.0 & 0.00 & 59.3 \\
\hline BACILLUS THURINGIENSIS SSP KURSTAKI & Insecticide & 35.8 & 0.00 & $28273.5^{*}$ \\
\hline BACILLUS THURINGIENSIS SSP ISRAELENSIS & Insecticide & 34.4 & 0.00 & $11079.8 *$ \\
\hline N-OCTYL BICYCLOHEPTENE DICARBOXIMIDE & Insecticide & 33.4 & 0.00 & 144.5 \\
\hline N-ALKYL POLYETHOXYETHANOL & Adjuvant & 32.5 & 0.00 & 52.5 \\
\hline METHYL NONYL KETONE & Rodenticide & 27.5 & 0.00 & 50.0 \\
\hline NICOTINE & Insecticide & 27.2 & 0.00 & 27.5 \\
\hline CYPERMETHRIN & Insecticide & 26.1 & 0.00 & 439.6 \\
\hline METHOXYCHLOR & Insecticide & 24.7 & 0.00 & 109.9 \\
\hline ZINC NAPHTHENATE & Anti-microbial & 23.6 & 0.00 & 40.0 \\
\hline PHOSALONE & Insecticide & 23.5 & 0.00 & 5.6 \\
\hline PYRIDABEN & Insecticide & 23.5 & 0.00 & 17.1 \\
\hline P-MENTHANE-3, 8-DIOL & Insecticide & 22.7 & 0.00 & \\
\hline 1-BROMO-3-CHLORO-5,5-DIMETHYLHYDANTOIN & Anti-microbial & 22.4 & 0.00 & 20.5 \\
\hline FENBUTATIN OXIDE & Insecticide & 22.1 & 0.00 & 12.4 \\
\hline TRIFORINE & Fungicide & 22.0 & 0.00 & 20.6 \\
\hline POLYMERIZED BUTENES & Rodenticide & 21.7 & 0.00 & 92.9 \\
\hline N-ALKYL DIETHANOLAMINE & Adjuvant & 20.8 & 0.00 & 33.6 \\
\hline HYDRAMETHYLNON & Insecticide & 20.4 & 0.00 & 9.2 \\
\hline TETRAMETHRIN & Insecticide & 20.3 & 0.00 & 14.2 \\
\hline OXADIAZON & Herbicide & 19.9 & 0.00 & 41.2 \\
\hline FORMALDEHYDE & Fungicide & 17.8 & 0.00 & 96.2 \\
\hline RESMETHRIN & Insecticide & 17.5 & 0.00 & 2.4 \\
\hline 1,2-ETHANEDIOL & Adjuvant & 17.4 & 0.00 & 87.0 \\
\hline OIL OF BLACK PEPPER & Rodenticide & 16.5 & 0.00 & 12.0 \\
\hline PARADICHLOROBENZENE & Insecticide & 13.9 & 0.00 & 65.3 \\
\hline PYRIDATE & Herbicide & 12.6 & 0.00 & 486.0 \\
\hline METHIOCARB & Insecticide & 12.1 & 0.00 & \\
\hline FERRIC PHOSPHATE & Insecticide & 11.3 & 0.00 & \\
\hline METOLACHLOR & Herbicide & 11.2 & 0.00 & 4297.9 \\
\hline DIMETHOMORPH & Fungicide & 9.9 & 0.00 & 72.9 \\
\hline KINOPRENE & Insecticide & 9.9 & 0.00 & 33.6 \\
\hline CYROMAZINE & Insecticide & 9.8 & 0.00 & \\
\hline TEBUFENOZIDE & Insecticide & 8.6 & 0.00 & \\
\hline COUMAPHOS & Insecticide & 7.3 & 0.00 & 45.6 \\
\hline D-PHENOTHRIN & Insecticide & 6.8 & 0.00 & \\
\hline ABAMECTIN & Insecticide & 6.7 & 0.00 & 3.6 \\
\hline METHOPRENE & Insecticide & 6.7 & 0.00 & \\
\hline DI-N-PROPYL ISOCINCHOMERONATE & Insecticide & 5.8 & 0.00 & 6.4 \\
\hline D-CIS, TRANS ALLETHRIN & Insecticide & 5.7 & 0.00 & 1.7 \\
\hline 10,10'-OXYBIS(PHENOXARSINE) & Preservative & 5.3 & 0.00 & \\
\hline
\end{tabular}




\begin{tabular}{|c|c|c|c|c|}
\hline ACTIVE INGREDIENT NAME & Type of use & \begin{tabular}{|l|}
2003 total \\
$(\mathrm{kg}$ ai $)$
\end{tabular} & \begin{tabular}{|l|l}
2003 & 1 \\
$\%$
\end{tabular} & \begin{tabular}{|l|}
1998 total \\
(kg ai)
\end{tabular} \\
\hline ETHION & Insecticide & 4.6 & 0.00 & 26.9 \\
\hline METHYL ANTHRANILATE & Rodenticide & 4.1 & 0.00 & \\
\hline FENVALERATE & Fungicide & 3.8 & 0.00 & 4.1 \\
\hline ALLETHRIN & Insecticide & 2.8 & 0.00 & 2.0 \\
\hline DIFLUBENZURON & Insecticide & 2.6 & 0.00 & \\
\hline FENHEXAMID & Fungicide & 2.5 & 0.00 & \\
\hline OXAMYL & Insecticide & 2.4 & 0.00 & 9.6 \\
\hline WARFARIN & Rodenticide & 2.0 & 0.00 & 1.8 \\
\hline SPINOSAD FACTOR A PLUS & Insecticide & 1.9 & 0.00 & \\
\hline CHLORPHACINONE & Rodenticide & 1.7 & 0.00 & 1.8 \\
\hline BROMADIOLONE & Rodenticide & 1.2 & 0.00 & 1.2 \\
\hline STREPTOMYCIN & Fungicide & 1.0 & 0.00 & 2.1 \\
\hline NATURAL GUM RESINS & Insecticide & 0.67 & 0.00 & 9.0 \\
\hline PIPERINE & Rodenticide & 0.62 & 0.00 & 0.4 \\
\hline AMMONIA & Rodenticide & 0.43 & 0.00 & 1.1 \\
\hline SULFAQUINOXALINE & Rodenticide & 0.41 & 0.00 & 1.4 \\
\hline DIPHACINONE & Rodenticide & 0.37 & 0.00 & 0.4 \\
\hline PROPETAMPHOS & Insecticide & 0.29 & 0.00 & \\
\hline PACLOBUTRAZOL & Growth Regulator & 0.23 & 0.00 & \\
\hline 4-AMINOPYRIDINE & Rodenticide & 0.21 & 0.00 & 1.5 \\
\hline MUSCALURE & Insecticide & 0.16 & 0.00 & 0.6 \\
\hline CAPSAICIN & Rodenticide & 0.10 & 0.00 & 0.1 \\
\hline FLAMPROP-M-METHYL & Herbicide & 0.08 & 0.00 & 1091.5 \\
\hline BRODIFACOUM & Rodenticide & 0.08 & 0.00 & 0.1 \\
\hline GIBBERELLIC ACID & Growth Regulator & 0.06 & 0.00 & 0.6 \\
\hline DIFETHIALONE & Rodenticide & 0.06 & 0.00 & \\
\hline DITHIOPYR & Herbicide & 0.05 & 0.00 & 2.1 \\
\hline 6-BENZYLAMINOPURINE & Growth Regulator & 0.04 & 0.00 & \\
\hline STREPTOMYCES GRISEOVIRIDIS & Fungicide & 0.04 & 0.00 & \\
\hline ANCYMIDOL & Growth Regulator & 0.03 & 0.00 & 0.1 \\
\hline CHOLECALCIFEROL & Rodenticide & 0.012 & 0.00 & 0.1 \\
\hline FENOXAPROP-ETHYL & Herbicide & 0.012 & 0.00 & 117.9 \\
\hline ERGOCALCIFEROL & Rodenticide & 0.002 & 0.00 & 0.02 \\
\hline GRAND TOTAL & & 9264487.7 & 100.0 & \\
\hline
\end{tabular}

Note: Bacillus thuringiensis active ingredient calculations in 1998 assumed that formulation consisted of $100 \%$ active ingredient, as guarantees on a percentage basis were not available. Guarantees on a percentage basis were obtained for these products in 2003. Recalculating the 1998 figures resulted in total active ingredient sold for Bt kurstaki and Bt israelensis of 617.994 and $1.654 \mathrm{~kg}$ ai, respectively. 


\begin{tabular}{|c|c|c|c|c|c|c|c|c|c|c|c|c|c|c|c|c|c|c|c|c|c|c|c|c|c|c|c|}
\hline & 昰 & $=$ & in & $\approx$ & $\begin{array}{l}n \\
\hat{n} \\
\text { ñ }\end{array}$ & 6 & & & & 6) & 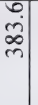 & 古 & $\begin{array}{l}-\dot{0} \\
\dot{0} \\
-\end{array}$ & i & ¿. & $\frac{\dot{0}}{2}$ & 0 & in & $\dot{0}$ & Бे & $\begin{array}{l}\dot{b} \\
\dot{w} \\
+\end{array}$ & 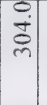 & ¿ & $\dot{m}$ & m & ले & 吕 \\
\hline & 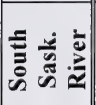 & & & & $\begin{array}{ll}6 \\
\text { in } \\
\text { in }\end{array}$ & 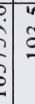 & & & & $\begin{array}{l}0 \\
8 \\
0 \\
0\end{array}$ & $\stackrel{0}{=}$ & $\dot{m}$ & 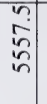 & 0 & & & $\begin{array}{l}0 \\
0 \\
0 \\
0\end{array}$ & "ñ. & & $i$ & $\begin{array}{l}\vec{d} \\
\vec{d}\end{array}$ & \begin{tabular}{|l|} 
\\
$\dot{2}$
\end{tabular} & 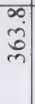 & $\overline{0}$ & $=$ & & $\begin{array}{l}n \\
\tilde{I}\end{array}$ \\
\hline & 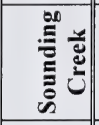 & & & & ¿ & i & & & & $\begin{array}{l}1 \\
0 \\
0 \\
0 \\
0\end{array}$ & & & & $\overline{0}$ & & $\begin{array}{l}+ \\
0 \\
0\end{array}$ & & & & & & & & $\begin{array}{l}0 \\
\vdots \\
0 \\
0\end{array}$ & & & \\
\hline & 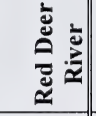 & & & & ฐั & 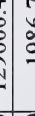 & & & & ¿্口 & $\therefore$ & $\stackrel{\Xi}{=}$ & $\begin{array}{c}0 \\
\infty \\
\infty \\
m\end{array}$ & $\dot{0}$ & $\stackrel{3}{0}$ & $\overline{2}$ & 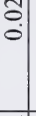 & 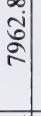 & & $\therefore$ & & & 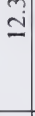 & 0 & \pm & & $\ddot{\sim}$ \\
\hline & 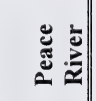 & & & & 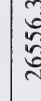 & ל: & & & & 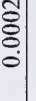 & & $\frac{a}{n}$ & & 文 & & $\begin{array}{l}0 \\
\grave{I}\end{array}$ & $\overrightarrow{0}$ & $\begin{array}{l}\vec{i} \\
\text { ปิ }\end{array}$ & & ले| & = & & & 0 & 8 & & 8 \\
\hline & | & & & & $\begin{array}{l}\infty \\
\bar{j} \\
\infty \\
\infty\end{array}$ & \begin{tabular}{c|c}
0 \\
$\vdots$ \\
$\vdots$ \\
0
\end{tabular} & & & & 管 & $\stackrel{n}{\sim}$ & 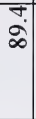 & : & $\begin{array}{l}n \\
0 \\
0 \\
0\end{array}$ & î̀ & in & $\begin{array}{l}\text { वें } \\
0 \\
0\end{array}$ & 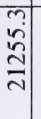 & & चे & $\begin{array}{l}0 \\
0 \\
\vdots \\
\vdots \\
\end{array}$ & $\begin{array}{l}0 \\
\infty \\
\infty\end{array}$ & 产 & ? & $\tilde{c}$ & & \begin{tabular}{|l}
0 \\
$\infty$ \\
$\infty$
\end{tabular} \\
\hline & 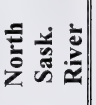 & & & & हิ & ?. & & & & 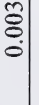 & $\stackrel{n}{\varrho}$ & $\begin{array}{l}0 \\
\ddot{m}\end{array}$ & & $\begin{array}{c}n \\
0\end{array}$ & & $\dot{m}$ & 年. & ì & & $\therefore$ & نे & $\mid \begin{array}{l}0 \\
\stackrel{0}{\grave{\Xi}}\end{array}$ & $\stackrel{0}{\dot{m}}$ & $\stackrel{?}{-}$ & $y$ & & 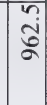 \\
\hline & 美竞: & & & & $\frac{\sqrt{2}}{3}$ & & & & & & & & & & & 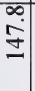 & & & & & & & & & & & \\
\hline & 胥: & & & & & & & & & & & & & & & & & & & & & & & & & & \\
\hline & 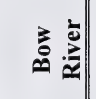 & & & & हैं & 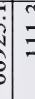 & & & & $\stackrel{-1}{n}$ & $\bar{\Xi}$ & $\begin{array}{l}n \\
\infty \\
\infty\end{array}$ & $\begin{array}{l}\infty \\
\stackrel{n}{\sim} \\
\end{array}$ & 0. & $\stackrel{\infty}{-}$ & ś & $\begin{array}{l}0 \\
0 \\
0\end{array}$ & $\begin{array}{l}\overrightarrow{0} \\
\approx\end{array}$ & $\begin{array}{l}8 \\
0 \\
0\end{array}$ & \& & iे & & 2 & $\begin{array}{c}\infty \\
\stackrel{n}{m}\end{array}$ & $n$ & 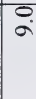 & 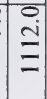 \\
\hline & 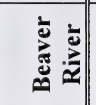 & & & & $\begin{array}{l}7 \\
\text { "ँ }\end{array}$ & $b^{2}$ & & & & 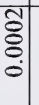 & & i. & & & & & & $\sigma$. & & & & & $\dot{0}$ & $\begin{array}{l}\pi \\
0 \\
0\end{array}$ & $\stackrel{\check{\Xi}}{0}$ & & $\begin{array}{l}0 \\
0 \\
0 \\
i\end{array}$ \\
\hline & 苛 & & & & $\frac{7}{2}$ & 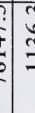 & & & & $\begin{array}{l}0 \\
8 \\
0 \\
0\end{array}$ & & $\stackrel{n}{m}$ & & 0 & & & $\begin{array}{l}\infty \\
0 \\
0 \\
0\end{array}$ & के & & $\dot{m}$ & $\begin{array}{l}7 \\
\infty \\
\infty \\
\infty\end{array}$ & & $\begin{array}{l}\infty \\
\ddot{b}\end{array}$ & ?. & \&̊ & & గु \\
\hline & 党 & & & & 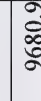 & 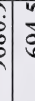 & & & & $\begin{array}{l}0 \\
\vdots \\
0 \\
0\end{array}$ & & $\stackrel{x}{+}$ & & $\stackrel{n}{0}$ & & ฮี. & $\begin{array}{l} \pm \\
\end{array}$ & $\begin{array}{l}0 \\
\infty \\
\vdots\end{array}$ & & - & $\stackrel{0}{-}$ & & $\ddot{0}$ & है. & $\Xi$ & & $\frac{0}{6}$ \\
\hline & 胥 & $\Xi$ & in & 9 & in & & 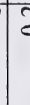 & & 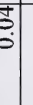 & ñ. & în & $\stackrel{m}{\stackrel{2}{a}}$ & & & $\stackrel{\overbrace{}}{\vec{\ddagger}}$ & mi & & & $\begin{array}{l}3 \\
\dot{0} \\
\dot{0}\end{array}$ & $\begin{array}{l}\infty \\
\substack{n \\
m}\end{array}$ & $\tilde{0}$ & & $\stackrel{n}{*}$ & $\stackrel{\vec{\sim}}{\stackrel{N}{*}}$ & $\stackrel{\circ}{\circ}$ & $\stackrel{\circ}{\stackrel{\sim}{*}}$ & $\stackrel{\sim}{i}$ \\
\hline & 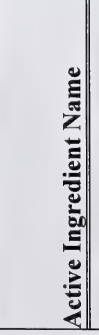 & 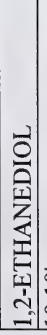 & 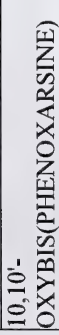 & 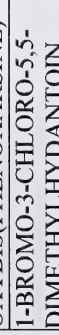 & 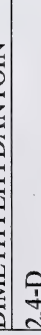 & 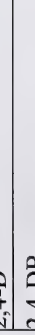 & & 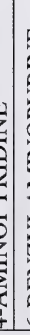 & 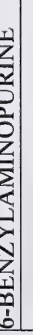 & 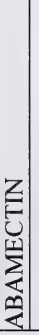 & 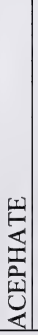 & 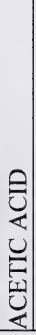 & 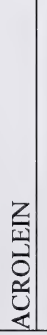 & 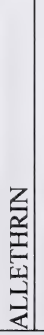 & 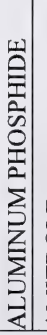 & 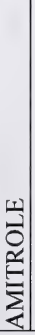 & 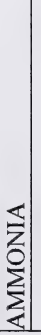 & 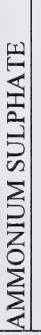 & 至 & 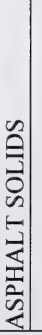 & 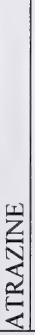 & 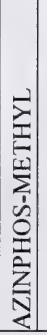 & \begin{tabular}{l}
$z$ \\
$z$ \\
0 \\
0 \\
\\
$\underline{n}$ \\
$x$ \\
0 \\
0 \\
\cline { 1 - 1 }
\end{tabular} & 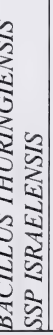 & 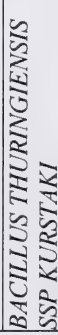 & 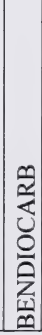 & 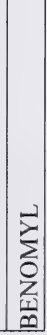 \\
\hline
\end{tabular}




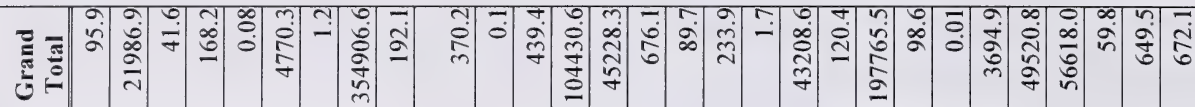

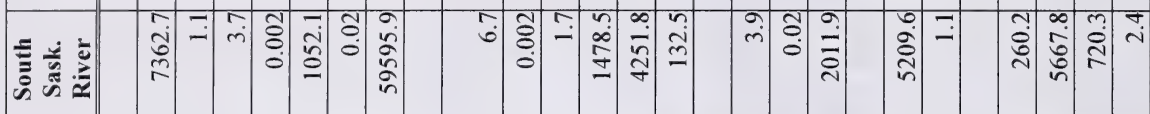

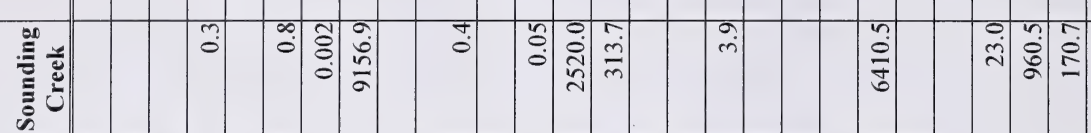

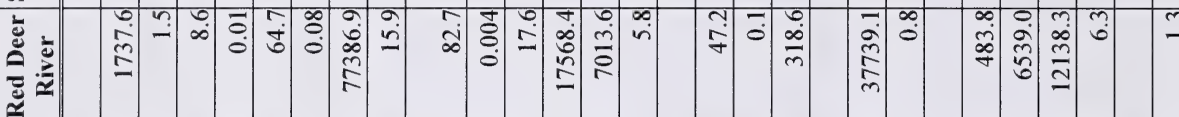

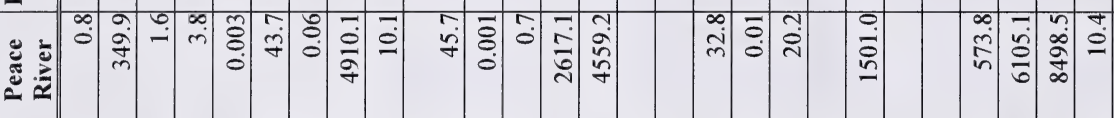

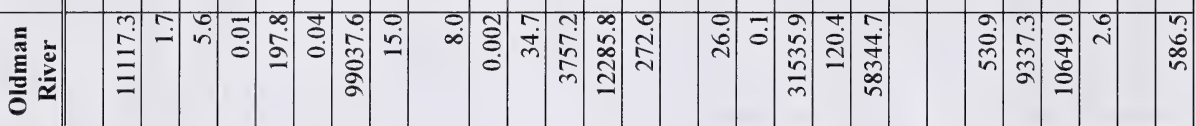

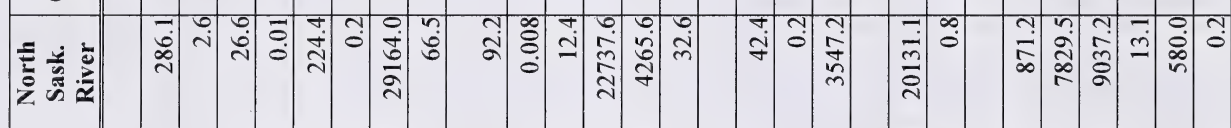

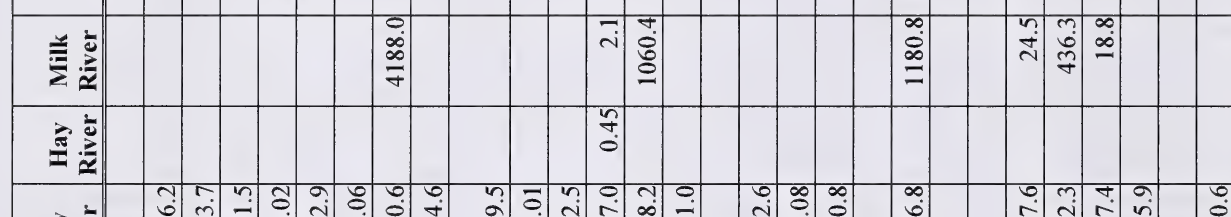

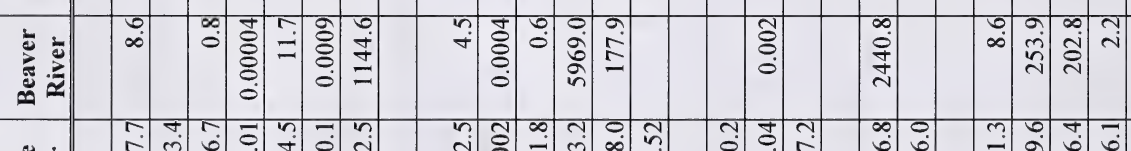

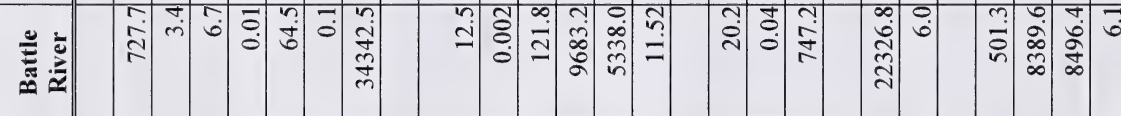

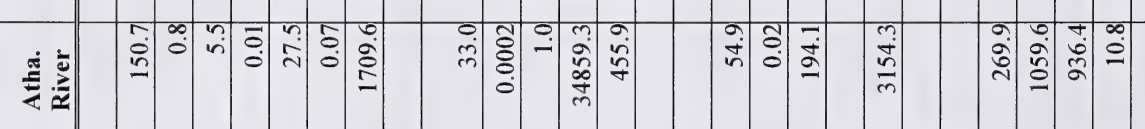

言

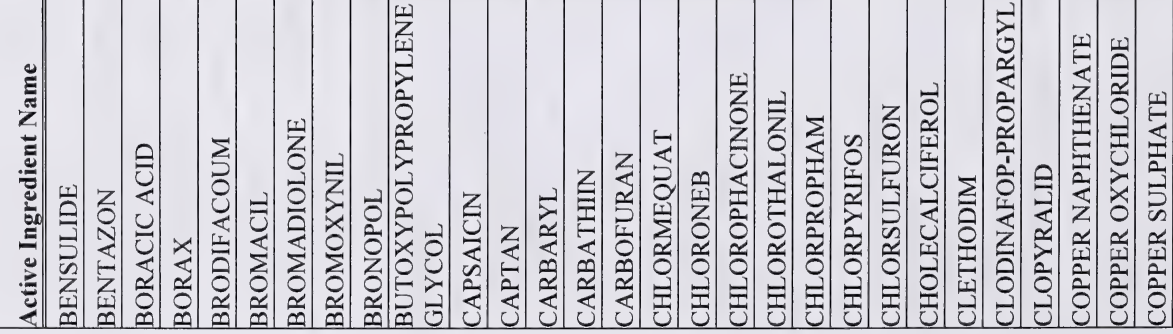




\begin{tabular}{|c|c|c|c|c|c|c|c|c|c|c|c|c|c|c|c|c|c|c|c|c|c|c|c|c|c|c|}
\hline 吾 & @. & $\stackrel{m}{r}$ & $\vec{\infty}$ & $\begin{array}{l}0 \\
0 \\
\infty \\
\infty \\
0\end{array}$ & ig & : & สู & $\frac{\dot{d}}{\bar{n}}$ & हैं & ป & 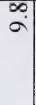 & $\stackrel{a}{\Xi}$ & & in & $\frac{m}{m}$ & 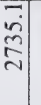 & & $\frac{a}{n}$ & & 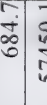 & & $6 \frac{2}{7}$ & $=\infty$ & 5 & 它 & \\
\hline 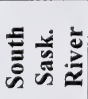 & 3 & & & ले & & & 0 & ปี & & $\stackrel{+}{-}$ & & & & 0 & $\hat{\varrho}$ & $\mathcal{F}$ & $\stackrel{-}{-}$ & نู & $\frac{m}{m}$ & त) & 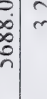 & 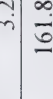 & & & ¿ें & $\begin{array}{c}\vec{D} \\
\substack{\infty \\
\infty}\end{array}$ \\
\hline لِّ & & & 0 & & & & $\begin{array}{l}\infty \\
\dot{m}\end{array}$ & ì & & & & & & $\begin{array}{l}0 \\
\vdots \\
0 \\
0\end{array}$ & $\infty$ & $\stackrel{g}{q}$ & & $m$ & 定? & $\therefore$ & 6 & 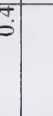 & & & $\sigma$ & \\
\hline 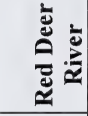 & $\stackrel{\vec{r}}{\dot{m}}$ &. & $\stackrel{8}{0}$ & $\stackrel{\infty}{\sim}$ & & & 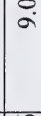 & \begin{tabular}{|c|}
$\bar{\infty}$ \\
0 \\
$\dot{y}$
\end{tabular} & & $\tilde{0}$ & & & & - & s. & ְै & $\stackrel{\infty}{-}$ & $\vec{o}$ & $\frac{\vec{a}}{\vec{a}}=$ & $\bar{F}$ & & 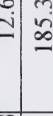 & $\therefore$ & & $\frac{\mathfrak{b}}{2}$ & 它 \\
\hline 离 & $\vec{i}$ & & & & & & 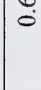 & $\stackrel{?}{\stackrel{m}{=}}$ & & $0^{\circ}$ & & & & $\stackrel{\tilde{c}}{0}$ & ڤ్ & 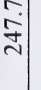 & 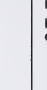 & $\stackrel{\sim}{m}$ & c. & b. & in & ri & & & \& & în \\
\hline 竎 & ๑ & & $\begin{array}{c}\infty \\
m\end{array}$ & 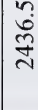 & v & & $\stackrel{0}{\mathrm{I}}$ & $\begin{array}{l} \\
\\
0 \\
0 \\
0\end{array}$ & {$\left[\begin{array}{c}0 \\
\infty \\
\infty \\
n\end{array}\right.$} & 它 & & & & 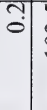 & 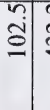 & 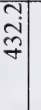 & $\begin{array}{l}\stackrel{n}{\tilde{y}} \\
= \\
=\end{array}$ & $\begin{array}{l}0 \\
\infty \\
\widehat{\sigma}\end{array}$ & \begin{tabular}{l|l}
$\overrightarrow{\mathrm{d}}$ \\
$\stackrel{\mathrm{m}}{\mathrm{m}}$
\end{tabular} & 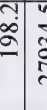 & & 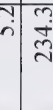 & $\hat{n}$ & & लें & $\begin{array}{l}0 \\
0 \\
0 \\
0 \\
0\end{array}$ \\
\hline 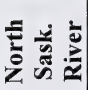 & $I$ & $0^{\circ}$ & $\underline{0}$ & হ & & & in & 官 & $\stackrel{0}{-}$ & in & & & & $\stackrel{-}{-}$ & $\begin{array}{l}0 \\
\dot{0} \\
\stackrel{2}{2}\end{array}$ & $\begin{array}{l}0 \\
\text { d. } \\
\text { లె }\end{array}$ & & $\begin{array}{c} \\
\vdots \\
\infty \\
\infty\end{array}$ & 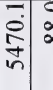 & 㐫 & ְ. & $\sqrt{2}$ & & & 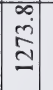 & 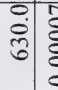 \\
\hline 差竞 & & & & & & & & $\begin{array}{l}0 \\
\infty\end{array}$ & & & & & & & & ? & & & o. & & & & & & 2 & \\
\hline 胥: & & & & & & & & & & & & & & & & & & & & & & & & & & \\
\hline 它: & त) & & 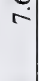 & 8 & & : & $=$ & $\begin{array}{l}0 \\
\check{\gamma}\end{array}$ & & a. & $\dot{+}$ & $\bar{\lambda}$ & $\begin{array}{c}\infty \\
\infty \\
\infty\end{array}$ & $\stackrel{0}{\infty}$ & $\begin{array}{l}\infty \\
\infty \\
\delta\end{array}$ & $\stackrel{2}{2}$ & $\dot{.}$ & $\stackrel{m}{\Sigma}$ & مُ & $\stackrel{8}{a}$ & $\frac{1}{\infty}$ & \pm & + & & 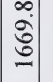 & $\stackrel{-1}{\simeq}$ \\
\hline 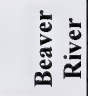 & & & & & & & & ¿े. & & & & & & $\begin{array}{l}\stackrel{8}{0} \\
\dot{0}\end{array}$ & 字 & $\dot{m}$ & & o. & & 8 & 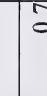 & $\vec{\sigma}$ & & & 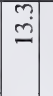 & \\
\hline 这 & $\stackrel{\circ}{-}$ & 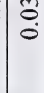 & & & & & $\infty$ & in & & 3 & & & & $\stackrel{7}{0}$ & तें & ڤ̊. & & $\stackrel{\vec{q}}{\Im}$ & 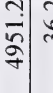 & हैं। & 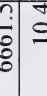 & 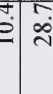 & & & :ิ & 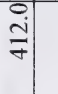 \\
\hline 吾离 & ${ }_{0}^{\circ}$ & $\stackrel{0}{0}$ & & & & & 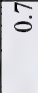 & $\overline{\dot{D}}$ & & : & & & & 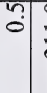 & $\overrightarrow{\bar{v}}$ & $\overrightarrow{\text { à }}$ & & $\vec{n}$ & $\exists=$ & $\mathrm{I}$ & $=$ & $\stackrel{m}{=}$ & & & 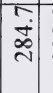 & ले \\
\hline 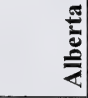 & $\stackrel{n}{n}$ & & & & & & $\vec{q}$ & & & $\stackrel{m}{-}$ & in & $\stackrel{0}{\circ}$ & & - & 年 & $\stackrel{n}{\sim}$ & & 辛 & 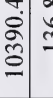 & 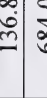 & 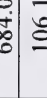 & : & 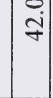 & 它 & $\stackrel{?}{-1}$ & \\
\hline 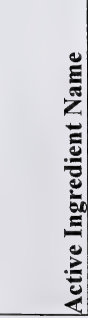 & 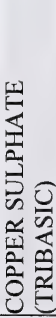 & $\sum_{0}^{\infty}$ & 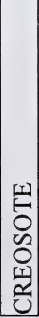 & 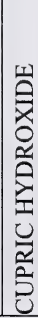 & $\frac{\substack{y \\
y \\
z}}{z}$ & 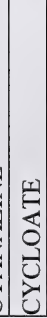 & 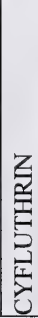 & 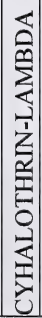 & $\begin{array}{l} \\
\vdots \\
\vdots \\
\vdots \\
\vdots \\
\vdots \\
\vdots \\
\vdots\end{array}$ & 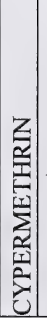 & 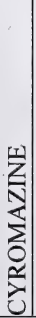 & 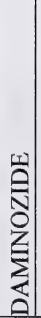 & 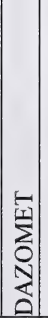 & 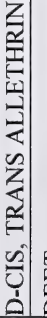 & 됨 & 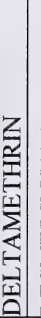 & 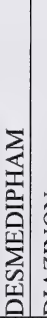 & \begin{tabular}{l}
$z$ \\
0 \\
$z$ \\
\cline { 1 - 1 } \\
$\vdots$ \\
0
\end{tabular} & $\sum_{\substack{n \\
0}}$ & 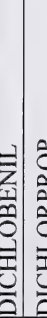 & 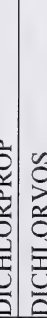 & 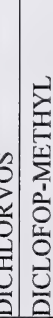 & 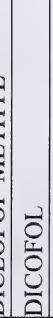 & 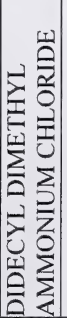 & 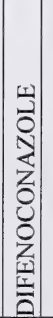 & 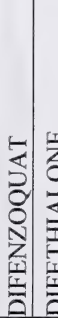 \\
\hline
\end{tabular}




\begin{tabular}{|c|c|c|c|c|c|c|c|c|c|c|c|c|c|c|c|c|c|c|c|c|c|c|c|c|c|c|c|}
\hline 焉 & $\sim$ & వ্] & 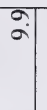 & in & 0 & $\begin{array}{l}+ \\
\dot{\sim} \\
\tilde{n} \\
\sim\end{array}$ & ڤ̊ & $\frac{8}{m}$ & $\begin{array}{l}\infty \\
\stackrel{\infty}{\sim} \\
\mathcal{f}\end{array}$ & \begin{tabular}{|l|}
$\infty$ \\
0 \\
\end{tabular} & 吕 & तิ่ & $\stackrel{m}{+}$ & $\begin{array}{l}0 \\
\stackrel{\dot{J}}{\sigma} \\
=\end{array}$ & ठ̊. & $\begin{array}{l}0 \\
\dot{n} \\
m \\
0 \\
0\end{array}$ & $\underset{\infty}{\dot{J}}$ & $\stackrel{3}{=}$ & $\stackrel{+}{+}$ & 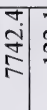 & $\overline{\mathrm{a}}$ & \begin{tabular}{l|l}
9 & \\
$\infty$ \\
$\infty$
\end{tabular} \mid & & in & & 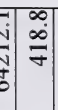 & \\
\hline 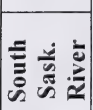 & & $\frac{\vec{m}}{m}$ & & $\stackrel{0}{0}$ & & 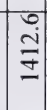 & & 8 & & $\overrightarrow{0}$ & $\stackrel{2}{-1}$ & लि & & $\begin{array}{l}0 \\
0 \\
0 \\
\text { d. } \\
\text { N. }\end{array}$ & & \begin{tabular}{l} 
गें \\
\} $\\
{\text { in }}$ & $\begin{array}{l}+8 \\
0\end{array}$ & & $\overline{0}$ & $\begin{array}{l}\infty \\
\\
\end{array}$ & & $\dot{j}$ & & & & 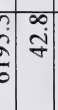 & \\
\hline 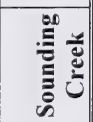 & & $\overrightarrow{0}$ & & & है & $\begin{array}{c}0 \\
\infty \\
\infty \\
\infty\end{array}$ & & ְ̋ & & & $\overline{0}$ & & & & & $\underset{\substack{\infty \\
\sim}}{\stackrel{0}{n}}$ & $\vec{a}$ & & त) & & 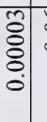 & $\stackrel{0}{\circ}$ & & & & 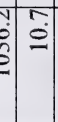 & \\
\hline 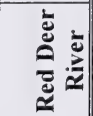 & & 具: & & $\begin{array}{l}0 \\
0\end{array}$ & ठิ & $\mid \begin{array}{c}- \\
\infty \\
\infty \\
n \\
n\end{array}$ & & $\stackrel{5}{0}$ & & $\overrightarrow{0}$ & 5 & $\begin{array}{l}0 \\
\infty\end{array}$ & & $\begin{array}{l}0 \\
\text { s. } \\
\text { s. }\end{array}$ & & $\begin{array}{l}0 \\
\\
\dot{\alpha} \\
\infty\end{array}$ & $\vec{气}$ & 文 & $\dot{0}^{\circ}$ & $\sqrt{2}$ & 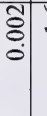 & $\stackrel{-}{-}$ & & & & 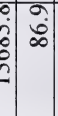 & $0 ี$ \\
\hline 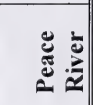 & & $\begin{array}{l}\infty \\
\infty \\
0 \\
0\end{array}$ & & $\stackrel{0}{-}$ & $\overline{0}$ & 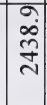 & & & & $\begin{array}{l}n \\
0 \\
0\end{array}$ & $\vec{i}$ & $\stackrel{0}{\infty}$ & & $\stackrel{\infty}{\infty}$ & & 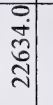 & $\begin{array}{l}\text { त. } \\
\text { d. } \\
\text { N. }\end{array}$ & & ?.? & & 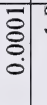 & $\stackrel{\infty}{-}$ & & & & 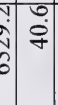 & $\begin{array}{l}\vec{J} \\
\dot{0}\end{array}$ \\
\hline 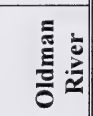 & & $\begin{array}{l}0 \\
0 \\
\dot{y}\end{array}$ & $\stackrel{n}{+}$ & $\overrightarrow{0}$ & ${ }_{0}^{0}$ & 它 & $\stackrel{8}{0}$ & i & & 0 & 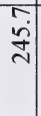 & 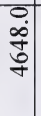 & $\stackrel{2}{\dot{y}}$ & 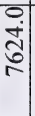 & & 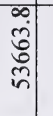 & $\stackrel{ \pm}{2}$ & 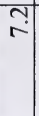 & $\stackrel{5}{0}$ & 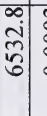 & $\begin{array}{l}0 \\
8 \\
0 \\
0\end{array}$ & - & & 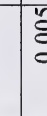 & & 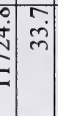 & 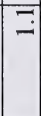 \\
\hline 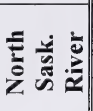 & & $\begin{array}{l}6 \\
\dot{2}\end{array}$ & & $\cong$ & $\stackrel{8}{0}$ & $\left|\begin{array}{l}n \\
\infty \\
\infty \\
0 \\
m\end{array}\right|$ & & $\stackrel{n}{i}$ & & 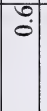 & $\begin{array}{l}\tilde{g} \\
\varrho\end{array}$ & 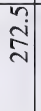 & & $\begin{array}{l}0 \\
\dot{0} \\
0 \\
0\end{array}$ & & $\begin{array}{c}m \\
\stackrel{f}{f} \\
f\end{array}$ & $\stackrel{0}{\beth}$ & & $\stackrel{I}{Z}$ & & $\begin{array}{l}\tilde{o} \\
\vdots \\
0\end{array}$ & $\tilde{\sigma}$ & & हٌ & & $\begin{array}{l}0 \\
0 \\
0 \\
0\end{array}$ & 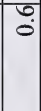 \\
\hline 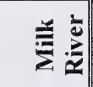 & & & & & & & & & & & ฮี & & & & & ֻே. & $\tilde{0}$ & & & & & $\begin{array}{l}0 \\
0 \\
0\end{array}$ & & & 8 & & \\
\hline 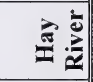 & & & & & & & & & & & & & & & & & & & & & & & & & & & \\
\hline 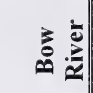 & & 文 & & $=$ & $\hat{O}$ & $\begin{array}{l}0 \\
\dot{\square}\end{array}$ & & $\vec{\circ}$ & - & $\begin{array}{l}+ \\
0\end{array}$ & $\overrightarrow{0}$ & $\begin{array}{l}0 \\
0 \\
0\end{array}$ & & $\stackrel{\sim}{\sim}$ & $\begin{array}{l}\text { है } \\
\vdots \\
0 \\
0\end{array}$ & $\begin{array}{l}\hat{n} \\
\hat{n} \\
y\end{array}$ & m. & $\stackrel{\vec{c}}{\mathrm{c}}$ & & $\stackrel{\infty}{+}+$ & m. & 9 & $\begin{array}{l}\infty \\
\stackrel{n}{m}\end{array}$ & & & 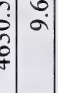 & $\hat{0}$ \\
\hline 竞 & & $a^{\circ}$ & & $\overrightarrow{0}$ & 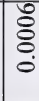 & $\dot{\mathrm{t}}$ & & $\overrightarrow{0}$ & & $\begin{array}{l} \\
\\
0\end{array}$ & $\hat{0}$ & & & & & ठ্ণ & $\stackrel{0}{+}$ & & & & & $\begin{array}{l}\infty \\
0 \\
0\end{array}$ & & & & 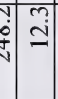 & \\
\hline 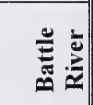 & & o & & กี & 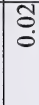 & 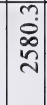 & & 3 & & $\overrightarrow{0}$ & $\vec{i}$ & & & : & & 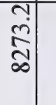 & 2 & & $\stackrel{0}{-1}$ & & & i. & & $\bar{\Xi}$ & & ç. & 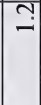 \\
\hline 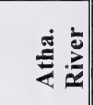 & & in & & $\stackrel{\circ}{-}$ & $\begin{array}{l}\text { ¿े } \\
8 \\
0 \\
0\end{array}$ & 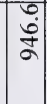 & & & & $\overline{0}$ & $\stackrel{i}{ }$ & & & & & $\begin{array}{l}0 \\
\vdots \\
\end{array}$ & iे & & $\stackrel{0}{\infty}$ & & $\begin{array}{l}n \\
0 \\
\vdots \\
\vdots \\
0 \\
0\end{array}$ & $\stackrel{m}{m}$ & & & & : & \\
\hline 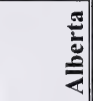 & & $\stackrel{a}{m}$ & & & $\stackrel{3}{0}$ & गें & & $\begin{array}{l}0 \\
8 \\
0 \\
\infty\end{array}$ & 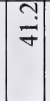 & $\vec{n}$ & $\begin{array}{c}n \\
\infty \\
+ \\
+\end{array}$ & תּู & & & 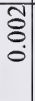 & & & $\begin{array}{l}\infty \\
\vdots \\
o\end{array}$ & & & $\begin{array}{l}m \\
\dot{\infty} \\
\dot{\infty}\end{array}$ & & $\begin{array}{l}+ \\
\infty\end{array}$ & & "a & & \\
\hline 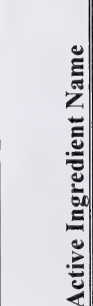 & 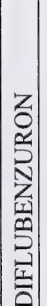 & 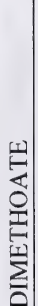 & 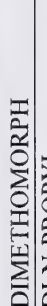 & 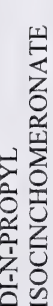 & 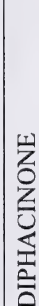 & $\frac{1}{3}$ & 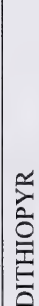 & 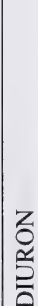 & 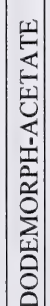 & 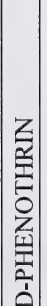 & 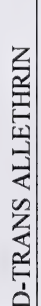 & $\begin{array}{l}z \\
z \\
\frac{1}{3} \\
0 \\
0 \\
0 \\
z \\
\vdots\end{array}$ & 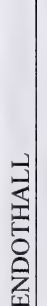 & $\frac{U}{2}$ & 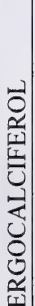 & 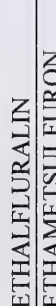 & 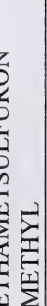 & 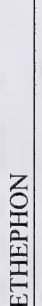 & $\begin{array}{l}z \\
\vdots \\
\underline{\Xi}\end{array}$ & 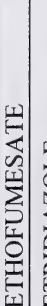 & 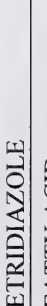 & 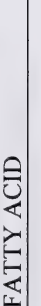 & 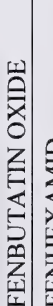 & 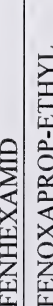 & 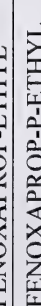 & 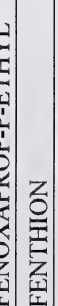 & 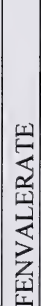 \\
\hline
\end{tabular}
\end{tabular}




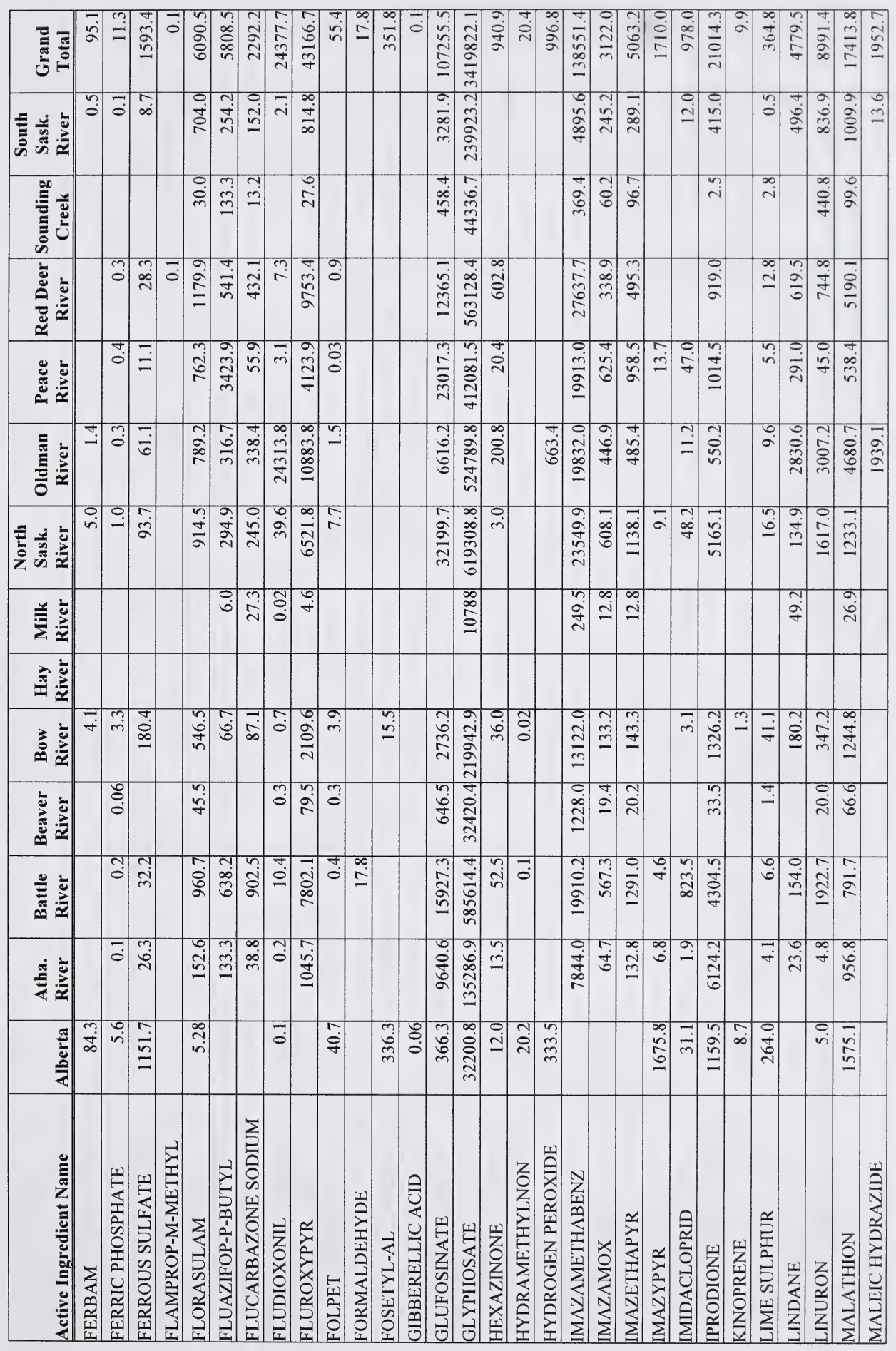




\begin{tabular}{|c|c|c|c|c|c|c|c|c|c|c|c|c|c|c|c|c|c|c|c|c|c|c|c|}
\hline 醇 & $\frac{a}{\stackrel{a}{0}}$ & 苟 & $\begin{array}{l}0 \\
\infty \\
0 \\
\hat{2} \\
\hat{0}\end{array}$ & $\stackrel{n}{\Xi}$ & 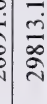 & کิ & $\stackrel{?}{-}$ & $\frac{\vec{b}}{\bar{\sigma}}$ & $\begin{array}{l}0 \\
0 \\
0 \\
0\end{array}$ & & & 0 & $\exists$ & $\stackrel{n}{\sim}$ & & $\begin{array}{l}= \\
= \\
= \\
0 \\
0 \\
0\end{array}$ & 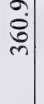 & $\stackrel{\vec{n}}{\vec{n}}$ & & $\frac{3}{F}$ & & $\stackrel{\infty}{\stackrel{0}{~}}$ & \\
\hline 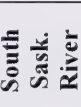 & $\frac{n}{6}$ & \begin{tabular}{l}
$\infty$ \\
$\infty$ \\
0 \\
\multirow{q}{*}{}
\end{tabular} & 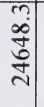 & d & : & & $\hat{\delta}$ & & & & $\frac{\pi}{n}$ & & & $\stackrel{0}{0}$ & & $\mid \begin{array}{l}n \\
n \\
n \\
n\end{array}$ & $\stackrel{N}{\approx}$ & in & $\stackrel{8}{\circ}$ & & & & \\
\hline
\end{tabular}

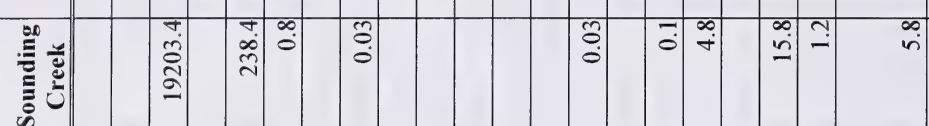

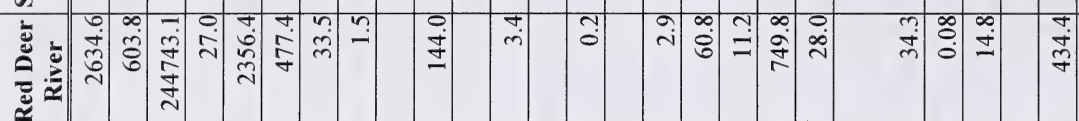

突

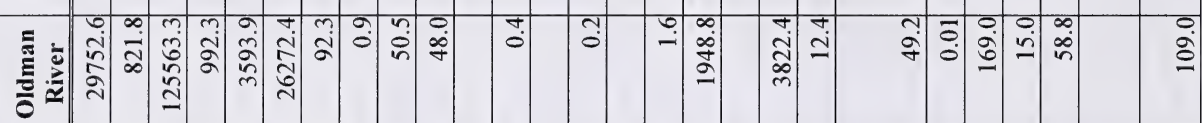

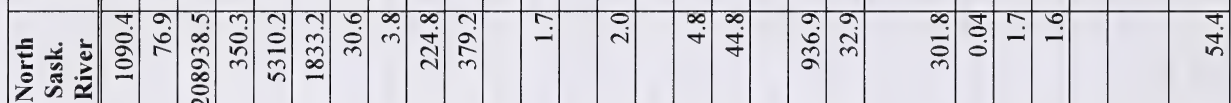

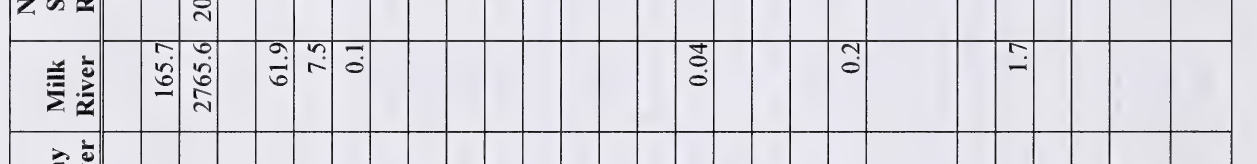

要

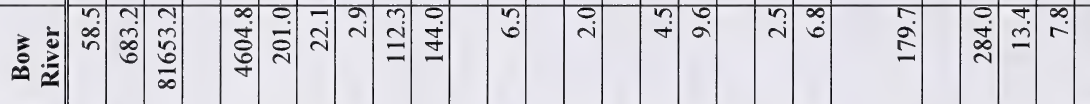

至

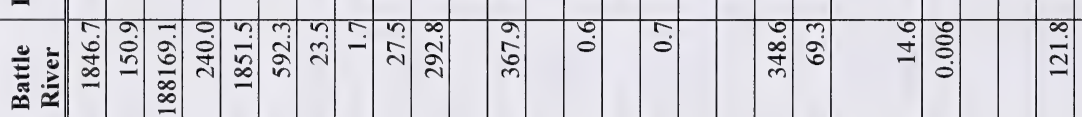

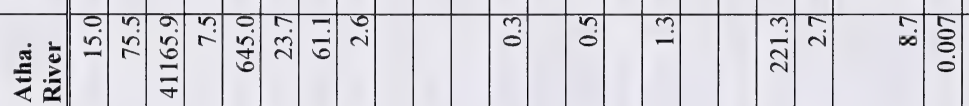

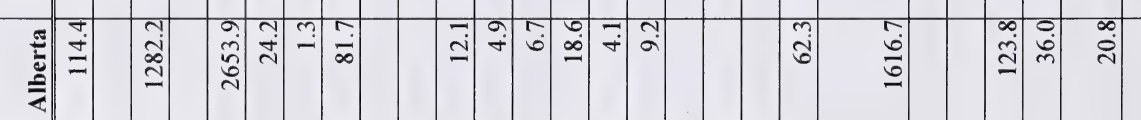

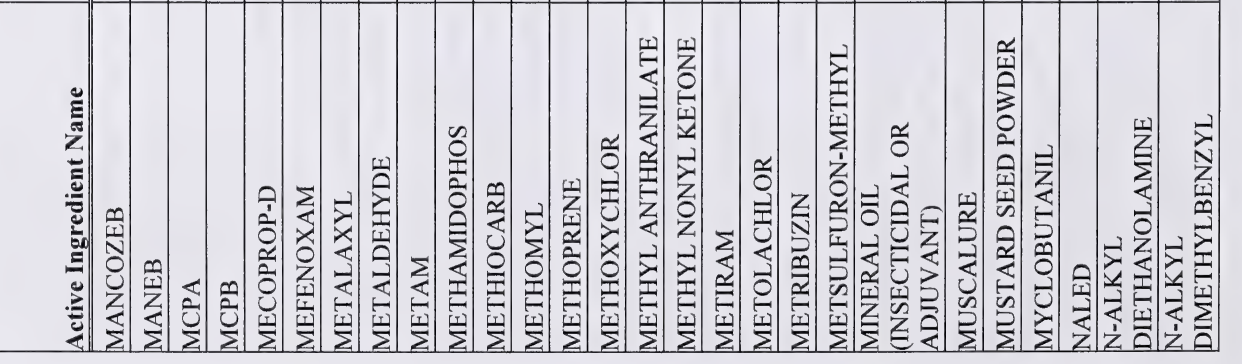




\begin{tabular}{|c|c|c|c|c|c|c|c|c|c|c|c|c|c|c|c|c|c|c|c|c|c|c|c|c|c|}
\hline 焉焉 & & 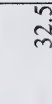 & $\begin{array}{l}n \\
\infty \\
=\end{array}$ & : & $\ddot{0}$ & $\overline{0}$ & त्ञ & लें & ${ }^{\infty}$ & & $\underset{\dot{m}}{\dot{J}}$ & " & $\mid \begin{array}{l}n \\
0 \\
0\end{array}$ & $\dot{a}$ & $\stackrel{+}{i}$ & in & $\cong$ & \begin{tabular}{|l|}
0 \\
\\
\end{tabular} & है: & \begin{tabular}{|c|} 
\\
2 \\
1
\end{tabular} & $\begin{array}{l}+ \\
\dot{J} \\
\tilde{J} \\
\text { a }\end{array}$ & $\begin{array}{l}+ \\
\infty \\
2 \\
2 \\
\end{array}$ & $\begin{array}{c}m \\
0 \\
0\end{array}$ & & \\
\hline 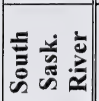 & & & & $\vec{i}$ & & $\vec{n}$ & & $:$ & $\begin{array}{l}7 \\
2 \\
2 \\
2\end{array}$ & & : & & ? & & & & & $\stackrel{\varrho}{\varrho}$ & & & $\begin{array}{l}\dot{0} \\
+\end{array}$ & $\frac{i}{2}$ & & & \\
\hline 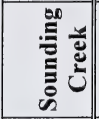 & & & 2 & & & & & $\overrightarrow{0}$ & $\underset{n}{\infty}$ & & $\stackrel{m}{=}$ & 8 & & & & & & & & $\stackrel{\circ}{-}$ & $\stackrel{0}{\stackrel{5}{f}}$ & $\stackrel{0}{\dot{I}}$ & & & \\
\hline 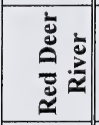 & & & $\begin{array}{l}\tilde{F} \\
\tilde{f}\end{array}$ & in & & in & & i & $\frac{\tilde{\sigma}}{\tilde{\alpha}}$ & & $\begin{array}{c}\frac{m}{\infty} \\
\frac{\infty}{N}\end{array}$ & & $\stackrel{0}{0}$ & & & $\stackrel{\overrightarrow{0}}{0}$ & & & & $\begin{array}{l}\infty \\
i \\
i\end{array}$ & $\begin{array}{l}\tilde{n} \\
\infty \\
0 \\
\tilde{n} \\
\tilde{\sigma}\end{array}$ & 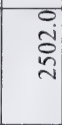 & 色 & $\begin{array}{c}2 \\
\infty \\
0 \\
0\end{array}$ & \\
\hline 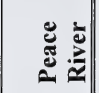 & & & త్ర & & & & & - & $\frac{1}{6}$ & & ¿. & & ? & & & $\overrightarrow{0}$ & & & & & 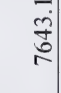 & $\begin{array}{l}\text { तुं } \\
\text { तै }\end{array}$ & & in & \\
\hline 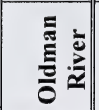 & & & $\underset{\sim}{\infty}$ & $\vec{\sim}$ & & in & & - & $\frac{7}{8}$ & & तิ & & 3 & & & $\overrightarrow{0}$ & & $\begin{array}{l}\infty \\
\infty \\
\infty\end{array}$ & & $\vec{n}$ & in & $\stackrel{\infty}{\stackrel{\infty}{\jmath}}$ & & $\begin{array}{l}0 \\
\stackrel{0}{0} \\
\beth\end{array}$ & $\begin{array}{l}\infty \\
\infty \\
\infty\end{array}$ \\
\hline 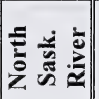 & & & $\stackrel{\sim}{+}$ & $\bar{I}$ & & $\begin{array}{l}0 \\
\stackrel{j}{j}\end{array}$ & & $\stackrel{\circ}{+}$ & $\frac{7}{\sigma}$ & & $\begin{array}{l}\bar{\infty} \\
0 \\
0\end{array}$ & & 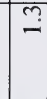 & & & $\tilde{m}$ & & $\begin{array}{l}\infty \\
\text { min }\end{array}$ & & $\stackrel{+}{+}$ & $\begin{array}{l}0 \\
\text { مे } \\
\text { సे }\end{array}$ & 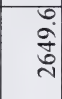 & & తิ) & \\
\hline 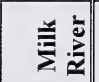 & & & & & & & & & & & $\begin{array}{l}\infty \\
\dot{\alpha}\end{array}$ & & & & & & & & & & $\begin{array}{l}0 \\
0 \\
0 \\
0\end{array}$ & $\stackrel{+}{ \pm}$ & & & \\
\hline 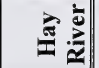 & & & & & & & & & & & & & & & & & & & & & & & & & \\
\hline 至高 & & & $\dot{\sim}$ & : & $\overline{0}$ & & iे & ใे & 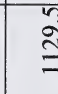 & & $\vec{\sigma}$ & & $\stackrel{I}{-}$ & $\ddot{0}$ & & ले & $\begin{array}{l}\infty \\
0 \\
\end{array}$ & $\vec{i}$ & & & 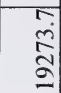 & 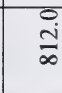 & & $\begin{array}{l}\overrightarrow{0} \\
\dot{0} \\
\end{array}$ & \\
\hline 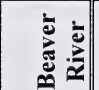 & & & & & & & & $\overrightarrow{0}$ & $\stackrel{\infty}{ٍ ్}$ & & & & : & & & & & & & & ㅇ. & $\bar{a}$ & & & \\
\hline 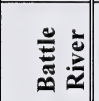 & & & & 9 & & $\frac{\pi}{\pi}$ & & $\stackrel{+}{-}$ & ลั & & $\bar{\infty}$ & & $\tilde{0}_{0}^{+}$ & & & : & & & & & 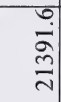 & $\begin{array}{l} \\
\\
\dot{0} \\
\end{array}$ & & 迥 & \\
\hline 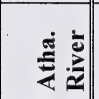 & & & $\stackrel{\infty}{+}$ & & & लె. & & i & m & & $\begin{array}{l}+\vec{\infty} \\
\end{array}$ & & $\begin{array}{c}\tilde{0} \\
0 \\
0\end{array}$ & & & & & & & & 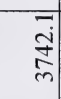 & $\frac{\sqrt{1}}{1}$ & & $\begin{array}{l}0 \\
\text { i. }\end{array}$ & \\
\hline 妾 & & m & & 6 & $\stackrel{0}{\circ}$ & & "ु) & $\stackrel{\mathrm{I}}{\mathrm{i}}$ & in & & $\begin{array}{l}\overrightarrow{0} \\
\vec{\nabla}\end{array}$ & & $\stackrel{ }{I}$ & $\stackrel{\check{2}}{2}$ & $\stackrel{\vec{s}}{\sim}$ & 学 & i̊ & & กु. & & & & & \pm & \\
\hline 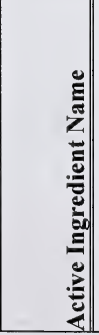 & 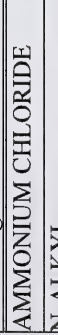 & 吾 & 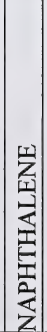 & 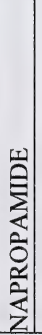 & $\begin{array}{l}n \\
z \\
0 \\
0 \\
a \\
\vdots \\
\vdots \\
0 \\
0 \\
\vdots \\
\vdots \\
\vdots \\
z\end{array}$ & 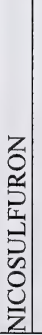 & 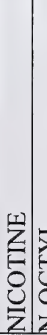 & 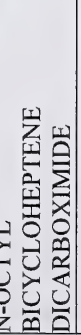 & 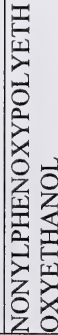 & 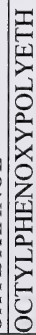 & 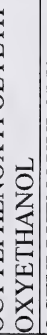 & 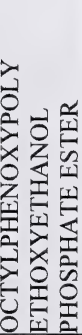 & 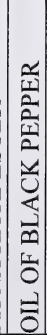 & z & $\sum_{x}^{2}$ & 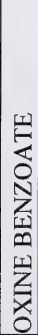 & 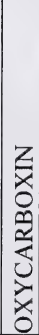 & 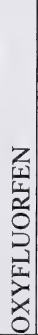 & 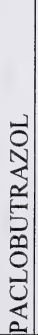 & 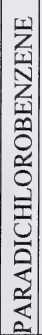 & 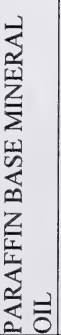 & 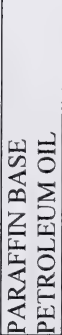 & 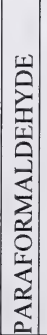 & 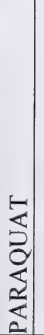 & 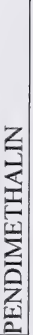 \\
\hline
\end{tabular}




\begin{tabular}{|c|c|c|c|c|c|c|c|c|c|c|c|c|c|c|c|c|c|c|c|c|c|c|c|c|c|c|}
\hline 焉 & $\mid \begin{array}{l}\infty \\
\stackrel{\infty}{m} \\
\dot{m}\end{array}$ & \begin{tabular}{l} 
oे \\
\multirow{N}{*}{} \\
in
\end{tabular} & $\begin{array}{l}n \\
\infty \\
m \\
m \\
m\end{array}$ & $\stackrel{\frac{3}{\sigma}}{\frac{3}{\sigma}}$ & चे & 守 & 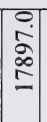 & $\square_{0}^{\circ}$ & $\begin{array}{l}\bar{b} \\
\bar{q}\end{array}$ & तु & $\overrightarrow{\mathrm{a}}$ & $\frac{\bar{v}}{\mathrm{~N}}$ & $\begin{array}{l}\stackrel{9}{\mathbf{N}} \\
\stackrel{1}{n} \\
\end{array}$ & in & $\begin{array}{l}3 \\
\infty \\
\infty \\
\infty\end{array}$ & $\stackrel{9}{\bar{z}}$ & $\begin{array}{l}0 \\
0 \\
0\end{array}$ & on: & $\begin{array}{c} \\
\dot{\infty} \\
\dot{m}\end{array}$ & 节 & & & & 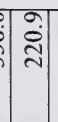 & & \\
\hline$\overline{\bar{z}} \overline{\bar{z}}$ & & $\begin{array}{l}\infty \\
\delta \\
\tilde{b} \\
\delta\end{array}$ & $\begin{array}{l}0 \\
\dot{\infty} \\
-\end{array}$ & $\stackrel{m}{=}$ & $\overline{0}$ & & & $\begin{array}{l}\overline{0} \\
0\end{array}$ & $\widehat{\beth}$ & $\begin{array}{l}0 \\
\dot{v} \\
\dot{m}\end{array}$ & $\begin{array}{l}\infty \\
0 \\
0\end{array}$ & & $\begin{array}{l}0 \\
\stackrel{0}{0} \\
0\end{array}$ & & 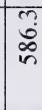 & & & & $\begin{array}{l}m \\
6 \\
6 \\
6 \\
0\end{array}$ & o. & & & & $\stackrel{\infty}{+}$ & & \\
\hline Uू. & $\overrightarrow{0}_{0}^{+}$ & ำ & & & & & & & $\Xi$ & & & & $\dot{\infty}$ & & & & & & 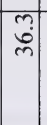 & ?ु & & & & 3 & & \\
\hline 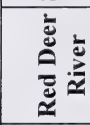 & $\stackrel{0}{\infty}$ & 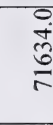 & $\stackrel{0}{\infty}$ & g & & & $\begin{array}{l}0 \\
\infty \\
\\
=\end{array}$ & है। & लें & ฮี & $\stackrel{m}{-}$ & & $\begin{array}{l}n \\
0 \\
\infty \\
\infty\end{array}$ & & & & $\stackrel{0}{\circ}$ & & 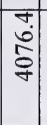 & $\stackrel{+}{\circ}$ & $\begin{array}{l}0 \\
\dot{f} \\
\dot{y}\end{array}$ & & $\stackrel{0}{\dot{+}}$ & $\stackrel{n}{ \pm}$ & & \\
\hline 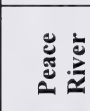 & $\infty$ & $\begin{array}{l}\infty \\
\stackrel{\infty}{\infty} \\
\stackrel{\infty}{*}\end{array}$ & & & & 0 & \begin{tabular}{|l|} 
\\
$b$ \\
\end{tabular} & $\begin{array}{l}\infty \\
\vdots \\
0 \\
0\end{array}$ & $\widehat{\vec{\lambda}}$ & & $\mathrm{S}$ & & $\begin{array}{l}\frac{a}{a} \\
\frac{\bar{n}}{n}\end{array}$ & & & & & & ते & $\begin{array}{l}\dot{0} \\
\dot{m}\end{array}$ & in & & $\begin{array}{l}\vec{d} \\
\stackrel{d}{\mathbf{d}}\end{array}$ & $\stackrel{0}{0}$ & & \\
\hline 离 & ๕̊․ & 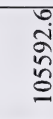 & 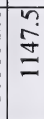 & 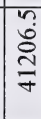 & $\dot{0}$ & : & 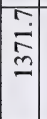 & $\begin{array}{l}\overline{0} \\
0\end{array}$ & 官 & : & กี & & $\begin{array}{l}\widetilde{0} \\
\stackrel{0}{=}\end{array}$ & & & 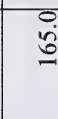 & & & 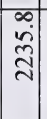 & G) & $\stackrel{n}{0}$ & & 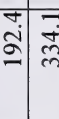 & $\vec{m}$ & & \\
\hline 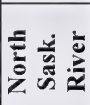 & लें & $\begin{array}{l}\infty \\
+ \\
+ \\
\infty\end{array}$ & & & $?$ & $\ddot{n}$ & 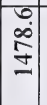 & $\begin{array}{l}n \\
\tilde{o} \\
0\end{array}$ & $\frac{m}{\infty}$ & - & $\vec{\infty}$ & & 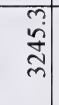 & & & & & ?. & 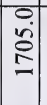 & $\stackrel{3}{=}$ & : & & 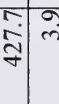 & $\vec{m}$ & & \\
\hline 产京 & & $\begin{array}{l}\infty \\
\stackrel{\infty}{+} \\
\stackrel{+}{+}\end{array}$ & & & & & & & $\begin{array}{l}0 \\
0 \\
0 \\
0\end{array}$ & & & & $\frac{\infty}{\sigma}$ & & & & & & & 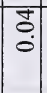 & & & $\begin{array}{l}\infty \\
\dot{m} \\
\dot{m}\end{array}$ & $\begin{array}{l} \\
0 \\
0 \\
0 \\
0\end{array}$ & & \\
\hline 胥: & & & & & & & & & & & & & & & & & & & & & & & & & & \\
\hline 言离 & $m$ & 官 & & & $\exists$ & & $\begin{array}{l}n \\
\infty \\
o \\
q\end{array}$ & $\begin{array}{l}\tilde{0} \\
\dot{0}\end{array}$ & tं & $\stackrel{\infty}{=}$ & 2 & $\vec{a}$ & nn & & & & & & & 售 & ¿ & & @i & : & & \\
\hline 㐫 & ? & ลิ宀 & & & & & $\stackrel{n}{\infty}$ & $\begin{array}{l}\tilde{\delta} \\
\vdots \\
0\end{array}$ & $\vec{m}$ & $\begin{array}{l}\infty \\
\stackrel{0}{0} \\
0\end{array}$ & กี & & in & & & & & & & $\tilde{0}$ & $\stackrel{\circ}{+}$ & & & 9 & & \\
\hline 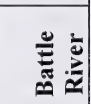 & $\hat{6}$ & \begin{tabular}{l}
$\infty$ \\
$\stackrel{\infty}{0}$ \\
\multirow{\sigma}{*}{}
\end{tabular} & & & & & ठ & ○े. & ते. & $0^{\circ}$ & $\tilde{\sigma}$ & & & & & & $\stackrel{0}{\dot{0}}$ & & 今. & $\vec{i}$ & $\stackrel{\infty}{r}$ & & $\begin{array}{l}n \\
\text { na }\end{array}$ & $\stackrel{2}{2}$ & & \\
\hline 焉 & बे & $\stackrel{\check{J}}{\Xi}$ & & & & & $\begin{array}{l}0 \\
\text { ते }\end{array}$ & $\begin{array}{l}\overline{\tilde{a}} \\
0 \\
0\end{array}$ & $\stackrel{\vec{d}}{\dot{d}}$ & . & $\stackrel{+0}{-}$ & & 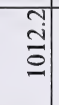 & & & & & & $\begin{array}{l}\infty \\
\infty \\
\infty \\
\tilde{n}\end{array} \mid$ & $\stackrel{m}{m}$ & i & & & $\begin{array}{l}\infty \\
0 \\
0\end{array}$ & & \\
\hline 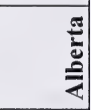 & ลे & & & & : & & $\begin{array}{l}\overrightarrow{\mathrm{i}} \\
\stackrel{\mathrm{a}}{\Xi}\end{array}$ & $?$ & @) & $\begin{array}{l}\infty \\
m \\
m\end{array}$ & & $\begin{array}{l}0 \\
\stackrel{i}{*}\end{array}$ & & के & & $\begin{array}{l}\stackrel{g}{0} \\
\text { j) }\end{array}$ & & & $\frac{\sim}{\vec{n}}$ & in. & $\tilde{a}$ & & & 孛 & $\frac{0}{\mathrm{\lambda}}$ & \\
\hline 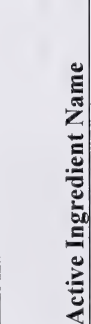 & 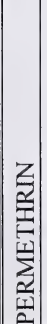 & 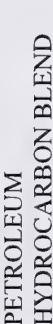 & 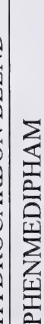 & 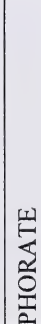 & 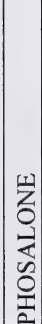 & $\begin{array}{l}-1 \\
\sum_{-1}^{-1} \\
0 \\
0 \\
0\end{array}$ & $\mid \begin{array}{l}\Sigma \\
\vdots \\
0 \\
0 \\
0 \\
0 \\
2\end{array}$ & 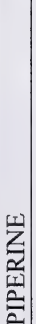 & 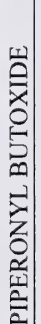 & 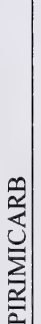 & 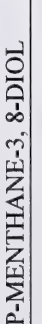 & 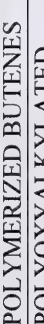 & 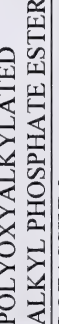 & 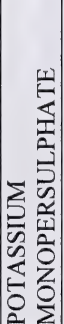 & 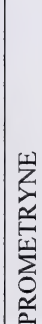 & 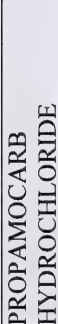 & 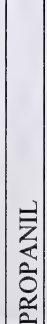 & 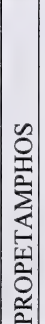 & 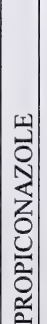 & 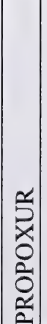 & 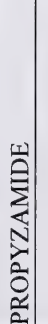 & 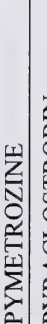 & 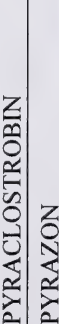 & 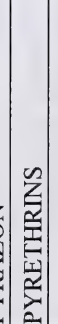 & 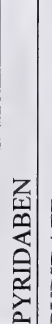 & 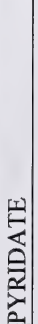 \\
\hline
\end{tabular}




\begin{tabular}{|c|c|c|c|c|c|c|c|c|c|c|c|c|c|c|c|c|c|c|c|c|c|c|c|c|c|c|}
\hline 鞄 & $\begin{array}{l}\vec{\infty} \\
\infty \\
\infty\end{array}$ & 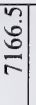 & 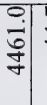 & f & 旾: & $\overrightarrow{\vec{\Delta}}$ & $\frac{1}{6}$ & 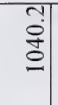 & लें & $\begin{array}{l}0 \\
\infty \\
\infty \\
\infty\end{array}$ & $\begin{array}{l}n \\
\infty \\
\infty \\
\infty \\
n \\
n \\
-1\end{array}$ & $\begin{array}{l}0 \\
\stackrel{0}{0} \\
=\end{array}$ & \begin{tabular}{l|l} 
\\
$\vdots$ \\
$\vdots$
\end{tabular} & & 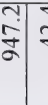 & i & ते & in & $\stackrel{n}{n}$ & 9 & $\begin{array}{l} \pm \\
0 \\
0\end{array}$ & - & $\stackrel{\substack{\infty \\
\sim}}{\sim}$ & & 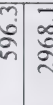 & 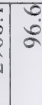 \\
\hline 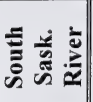 & & 2 & $\stackrel{m}{m}$ & : & $0^{\circ}$ & & $\vec{i}$ & n. & : & ?. & $\begin{array}{l}\frac{a}{5} \\
\vdots \\
-\end{array}$ & & $\infty$ & ") & in & & & $\simeq$ & 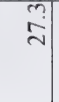 & & & & 0 & 0 & $\because \sigma$ & \\
\hline 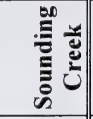 & & $\dot{9}$ & $\begin{array}{l}\dot{\lambda} \\
\dot{\lambda}\end{array}$ & & $\begin{array}{l}\text { ô. } \\
0 \\
0\end{array}$ & & ó & $\stackrel{0}{0}$ & 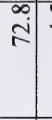 & $\stackrel{n}{+}$ & $\stackrel{2}{\pi}$ & & $\overrightarrow{0}$ & & $\begin{array}{c}3 \\
0\end{array}$ & & & o. & $\stackrel{\text { i }}{\text { in }}$ & & & & mें & & & \\
\hline 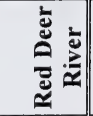 & $\stackrel{\infty}{=}$ & ले & ले & - & + & ๑ै: & $\dot{+}$ & o. & $\stackrel{m}{\bar{\Xi}}$ & ڤ̊. & ले & & : & הె & ? & & $\stackrel{\vec{\sigma}}{a}$ & 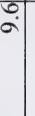 & $\overline{\mathrm{N}}$ & & & & : & $:$ & & i \\
\hline 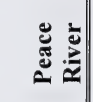 & ڤें & ? & הั) & $\vec{i}$ & 9 & & in. & $=$ & $\frac{2}{\infty}$ & ì. & 年 & & $\stackrel{\infty}{\infty}$ & & $\overline{\mathbf{i}}$ & & & & & & & & & $\stackrel{0}{0}$ & $\stackrel{\square}{b}$ & $\stackrel{\infty}{2}$ \\
\hline 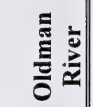 & & 字 & ț & 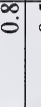 & 0 & | & $\overrightarrow{+}$ & हे. & $\begin{array}{l}0 \\
\dot{0} \\
0 \\
0\end{array} \mid$ & ले & 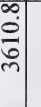 & & 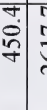 & 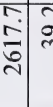 & ले: & 文 & $\begin{array}{l}\text { s. } \\
\stackrel{1}{0} \\
0\end{array}$ & 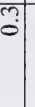 & $\hat{0}$ & & & & $\begin{array}{l}n \\
n \\
n\end{array}$ & $\stackrel{0}{0}$ & 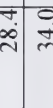 & $\infty$ \\
\hline 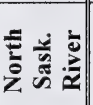 & సิ่ & $\stackrel{\infty}{\infty}$ & 年 & ○. & $\dot{m}$ & $\stackrel{\infty}{\infty}$ & $\stackrel{5}{=}$ & - & în. & ڤn: & ב̃. & & 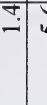 & $\begin{array}{l}\overrightarrow{0} \\
\dot{m}\end{array}$ & $\begin{array}{c}n \\
\\
\end{array}$ & & $\exists$ & 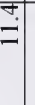 & ชู & & & & \begin{tabular}{c|}
0 \\
$\infty$ \\
$\infty$ \\
+
\end{tabular} & : & 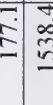 & 2 \\
\hline 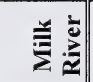 & & & 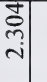 & & & & $\overrightarrow{0}$ & $\begin{array}{l}0 \\
0 \\
0\end{array}$ & 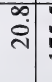 & 气. & $\underline{n}$ & & & & $\begin{array}{l}\overline{0} \\
0\end{array}$ & & $\exists$ & & & & & & $\begin{array}{l}\overrightarrow{0} \\
0\end{array}$ & & & \\
\hline 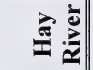 & & & & & & & & & & & & & & & & & & & & & & & & & & \\
\hline 竞: & & 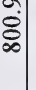 & ปे & & $\vec{i}$ & & ठे. & $\frac{?}{5}$ & 竎 & : & 綮 & & $\overrightarrow{0}$ & & î. & : & \begin{tabular}{l}
2 \\
\hdashline \\
0
\end{tabular} & $\vec{i}$ & $\dot{\tau}$ & & & & $\overline{\mathrm{I}}$ & $\begin{array}{l}n \\
0 \\
0 \\
0\end{array}$ & iे & \\
\hline 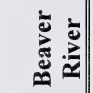 & & $\infty$ & $\stackrel{0}{ \pm}$ & & రె. & & $\tilde{0}$ & है. & $\begin{array}{l}\infty \\
\vdots \\
0\end{array}$ & & 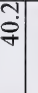 & & & & $\begin{array}{l}0 \\
\text { m. }\end{array}$ & & & $\bar{i}$ & (.) & & & & & 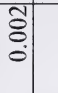 & m & \\
\hline 吾苛 & 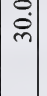 & $\begin{array}{c}n \\
\text { ñ. }\end{array}$ & $\stackrel{0}{\Delta}$ & i. & $\dot{0}$ & 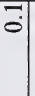 & $\vec{i}$ & $\hat{0}$ & $\begin{array}{l}0 \\
\vdots \\
\infty \\
n \\
n\end{array} \mid$ & 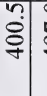 & 晏. & & 定 & & $\stackrel{1}{9}$ & & & bे & $\stackrel{m}{n}$ & & & & & $\stackrel{9}{9}$ & & $\stackrel{+}{+}$ \\
\hline 童 & ?ִ & : & : & & $\exists$ & & त्) & $\stackrel{\infty}{\circ}$ & \begin{tabular}{c|c}
0 \\
$\bar{\infty}$
\end{tabular} & $\dot{\infty}$ & के & & $\tilde{\dot{\theta}}$ & & $\infty$ & : & & & & & & & & \begin{tabular}{l|l}
0 \\
0
\end{tabular} & 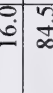 & $\stackrel{?}{=}$ \\
\hline | & & 文 & & & $i$ & & $\begin{array}{l}n \\
m \\
m\end{array}$ & $\begin{array}{l}0 \\
\tilde{n} \\
n \\
n\end{array}$ & & & 字 & $\begin{array}{l}0 \\
\grave{n} \\
=\end{array}$ & 离 & & \begin{tabular}{c|c}
$\infty$ & \\
0 & 0 \\
& 0
\end{tabular} & 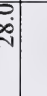 & & $\begin{array}{l}\infty \\
0 \\
0\end{array}$ & $\vec{\sim}$ & 9 & $\stackrel{0}{0}$ & $\stackrel{9}{-}$ & - & & in & \\
\hline 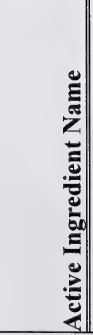 & 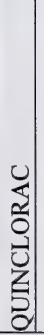 & 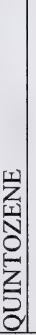 & 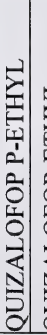 & 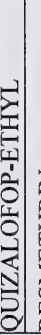 & 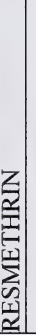 & 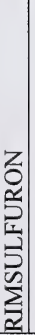 & ב & 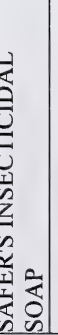 & 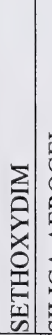 & 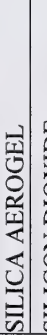 & 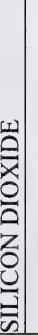 & 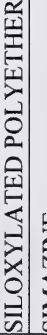 & 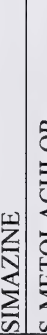 & 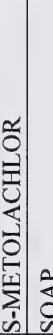 & 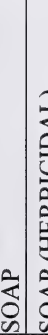 & 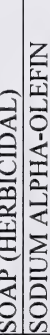 & 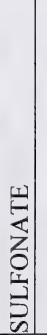 & 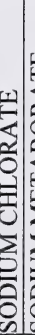 & 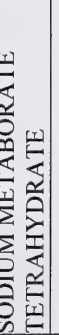 & 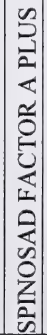 & 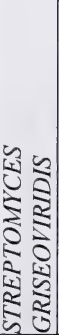 & $\begin{array}{l}z \\
0 \\
z \\
\vdots \\
0 \\
0 \\
0 \\
0 \\
0 \\
0 \\
0\end{array}$ & 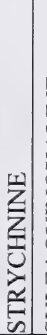 & 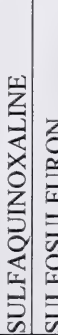 & 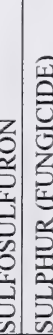 & 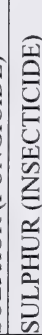 \\
\hline
\end{tabular}




\begin{tabular}{|c|c|c|c|c|c|c|c|c|c|c|c|c|c|c|c|c|c|c|c|c|c|c|c|c|c|c|c|c|}
\hline 豆 & $\stackrel{\infty}{\infty}$ & $\begin{array}{l}\tilde{D} \\
\tilde{\infty} \\
\tilde{\sigma} \\
\tilde{\gamma}\end{array}$ & 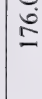 & 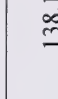 & $\hat{l}_{0} \hat{\delta}_{i}$ & v & 6 & लि & 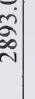 & ㄱ & $\begin{array}{c}\infty \\
\stackrel{\infty}{=} \\
\stackrel{2}{2}\end{array}$ & $\stackrel{\circ}{=}$ & $\begin{array}{c}i \\
\hat{\infty}\end{array}$ & $\stackrel{+}{q}$ & 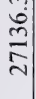 & 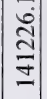 & 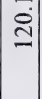 & 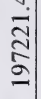 & 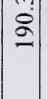 & 辛 & ले & $\stackrel{0}{m}$ & 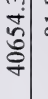 & $\infty \approx$ & तi & 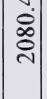 & $\underset{\stackrel{d}{\sim}}{\stackrel{\sim}{N}}$ & \\
\hline 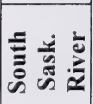 & & $\begin{array}{c}\stackrel{0}{i} \\
\hat{n} \\
\tilde{m}\end{array}$ & & $\stackrel{\infty}{\beth}$ & 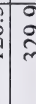 & & & $\infty$ & $\frac{7}{n}$ & 0 & $\stackrel{\infty}{\sim}$ & 0 & ڤें & $\Xi$ & $\begin{array}{l}\dot{\hat{D}} \\
\stackrel{i}{N}\end{array}$ & $\left|\begin{array}{|c|}\infty \\
\vdots \\
\vdots \\
\alpha \\
\gamma\end{array}\right|$ & & $\stackrel{m}{7}$ & & ثे & $\stackrel{\infty}{=}$ & $\begin{array}{c}0 \\
\dot{0} \\
+\end{array}$ & $\frac{\circ}{2}$ & & $\circ$ & $\dot{\infty}$ & 常 & \\
\hline 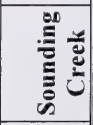 & & $\underset{\infty}{\infty}$ & & & & & & - & & $0^{\circ}$ & $\mathrm{i}$ & & $\frac{0}{6}$ & $\begin{array}{l}0 \\
\vdots \\
0 \\
0\end{array}$ & 8 & $\frac{0}{6}$ & & 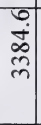 & & $\bar{a}$ & $\vec{m}$ & & 字 & & & $\stackrel{\dot{\sim}}{\mathrm{i}}$ & & \\
\hline 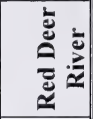 & $\cong$ & त̂ & & & gู & & & & i. & 0 & $\infty$ & 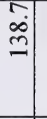 & ڤై & $\because$ & हैं & $\mid \begin{array}{c}\vec{n} \\
\hat{n} \\
\infty \\
\tilde{m}\end{array}$ & ले & $\begin{array}{l}c \\
0 \\
\infty \\
\infty \\
\infty\end{array}$ & F & ¿ू. & $\stackrel{m}{2}$ & $\stackrel{n}{=}$ & हn & :. & 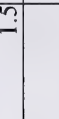 & $\frac{\dot{v}}{\dot{y}}$ & ஸे. & $\dot{0}$ \\
\hline 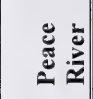 & & $\begin{array}{l}\text { o } \\
\text { ठे } \\
\text { fे }\end{array}$ & & $\sigma$ & 2 & & & & & ?. & & $\stackrel{n}{\sim}$ & : & $\stackrel{2}{=}$ & . & \begin{tabular}{|c|} 
\\
0 \\
0 \\
0 \\
$i n$
\end{tabular} \mid & $\stackrel{2}{2}$ & $\overrightarrow{\mathrm{a}}$ & กิ & $\left|\begin{array}{l}n \\
i \\
i \\
n\end{array}\right|$ & ชุ. & in & $\begin{array}{l}\text { ते } \\
\text { సิ }\end{array}$ & & : & : & & \\
\hline 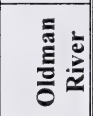 & $\stackrel{+}{=}$ & {$\left[\begin{array}{l}\infty \\
\infty \\
\infty \\
\infty \\
\alpha \\
\alpha\end{array}\right.$} & & & g & & & 2 & $\begin{array}{c}0 \\
\stackrel{\infty}{*} \\
\end{array}$ & 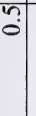 & 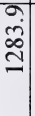 & iे & $\frac{n}{\infty}$ & $\stackrel{9}{\grave{0}}$ & 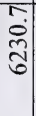 & 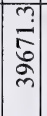 & : & 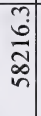 & & $\mid$ & $\begin{array}{l}\vec{m} \\
\stackrel{2}{2}\end{array}$ & : & 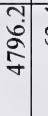 & & & $\vec{\nabla}$ & 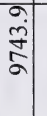 & \\
\hline 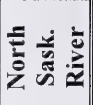 & $\stackrel{q}{q}$ & $\begin{array}{l}\tilde{V} \\
\tilde{b} \\
0 \\
0\end{array}$ & & & d & & & - & $\vec{v}$ & $m$ & - & 这 & : & : & $\begin{array}{l}\vec{\Delta} \\
\dot{0} \\
\infty\end{array}$ & $\begin{array}{l}\text { r. } \\
\grave{2} \\
\infty \\
\infty\end{array}$ & & $\begin{array}{l}0 \\
\stackrel{0}{n} \\
n\end{array}$ & à & $\begin{array}{l}a \\
\infty \\
a\end{array}$ & 它 & $\stackrel{n}{\bar{\infty}}$ & $\begin{array}{c}\infty \\
\infty \\
0 \\
0 \\
m\end{array}$ & & & 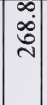 & 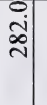 & \\
\hline 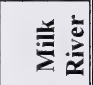 & & $\stackrel{1}{\circ}$ & & & $\infty$ & & & & & & $\therefore$ & 9 & $\vec{m}$ & & m. & 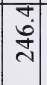 & & $\underset{\infty}{\infty}$ & & $\stackrel{-}{-}$ & & & त. & & & + & & \\
\hline 产: & & & & & & & & & & & & & & & & & & & & & & & & & & & & \\
\hline 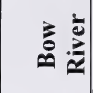 & 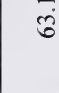 & 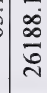 & ○े & & $\stackrel{\Omega}{\Omega}$ & & & & ¿ & - & - & in & రై & तु & ஸें & 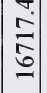 & $\stackrel{0}{0}$ & 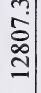 & $\stackrel{3}{i}$ & 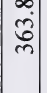 & iे. & $\begin{array}{l}0 \\
0 \\
0 \\
0\end{array}$ & 它 & & రु. & $\cong$ & $\overleftarrow{6}$ & $\stackrel{0}{0}$ \\
\hline 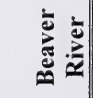 & $\stackrel{0}{0}$ & 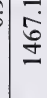 & & & I & & & & & $\overrightarrow{0}$ & & ते & 它 & $\overrightarrow{0}$ & ปे & $\mid$\begin{tabular}{|c|}
$\mid \begin{array}{l}0 \\
\\
n\end{array}$ \\
\end{tabular} & $\mid \begin{array}{l}\infty \\
\mathbf{i} \\
\mathbf{i}\end{array}$ & $\begin{array}{l}0 \\
\dot{0} \\
6 \\
\sigma\end{array}$ & & $\mid \begin{array}{l}0 \\
0 \\
0 \\
0\end{array}$ & $\begin{array}{l}n \\
n \\
m\end{array}$ & 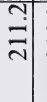 & $\frac{0}{m}$ & & & & & \\
\hline 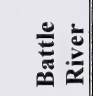 & 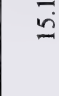 & $\begin{array}{l}n \\
\infty \\
0 \\
0 \\
0\end{array}$ & & & ]े & & & & i. & $\exists$ & $\stackrel{0}{+}$ & $\begin{array}{l}\overline{0} \\
8 \\
+\end{array}$ & $\begin{array}{l}\infty \\
\infty \\
\infty \\
=\end{array}$ & $\begin{array}{l}\infty \\
i \\
i\end{array}$ & 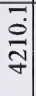 & \begin{tabular}{|c|} 
\\
0 \\
0 \\
$\delta$ \\
0 \\
\end{tabular} & $\mid$ & 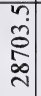 & : & ¿े̀ & $\frac{7}{n}$ & $\stackrel{+}{\dot{y}}$ & 递 & & @) & $\frac{F}{\bar{f}}$ & 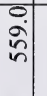 & \\
\hline 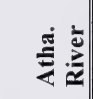 & I. & $\frac{\hat{n}}{\hat{E}}$ & & & $\ddot{0}$ & & & & & 9 & & 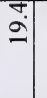 & $\vec{\infty}$ & $\vec{\nabla}$ & ले & $\mid$ & & $\begin{array}{l}\dot{\infty} \\
\frac{\infty}{2}\end{array}$ & & $\vec{\sim}$ & 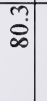 & $\begin{array}{l}0 \\
\text { n. }\end{array}$ & $\begin{array}{l}0 \\
\infty \\
0\end{array}$ & & 0 & ¿े & 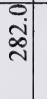 & \\
\hline 竎 & $\stackrel{\infty}{\tilde{\imath}}$ & $\begin{array}{l}n \\
\sim \\
\infty \\
\infty\end{array}$ & $\begin{array}{l}\infty \\
\infty \\
0 \\
0\end{array}$ & & & 5 & & P. & & 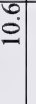 & & $\stackrel{Y}{ \pm}$ & & ర్ర & $\begin{array}{l}0 \\
\text { ju } \\
\text { the }\end{array}$ & & & & & & & $\begin{array}{l}\text { तें } \\
\text { ¿े } \\
\text { הे }\end{array}$ & & & & & & \\
\hline 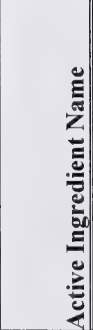 & 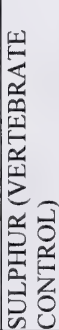 & 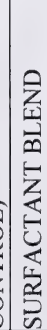 & 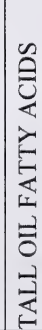 & 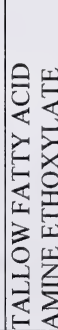 & 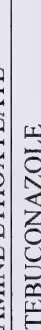 & 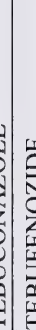 & है. & 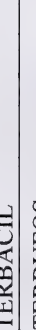 & 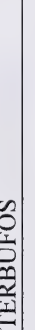 & 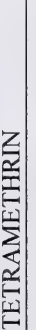 & 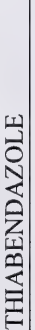 & 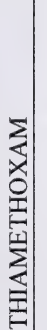 & 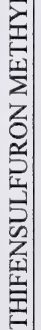 & 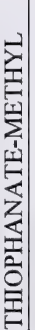 & $\sum$ & 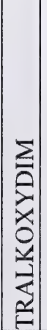 & 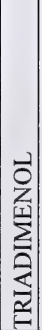 & 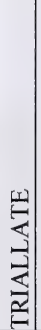 & 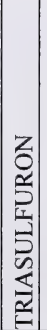 & 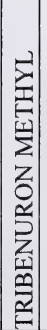 & 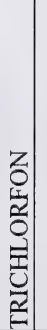 & 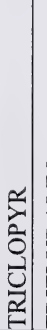 & 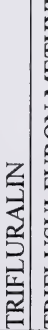 & 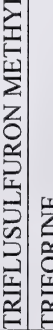 & 言 & 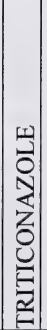 & 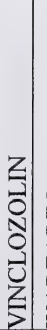 & $\begin{array}{l}2 \\
z \\
z \\
z \\
z \\
z \\
z\end{array}$ \\
\hline
\end{tabular}




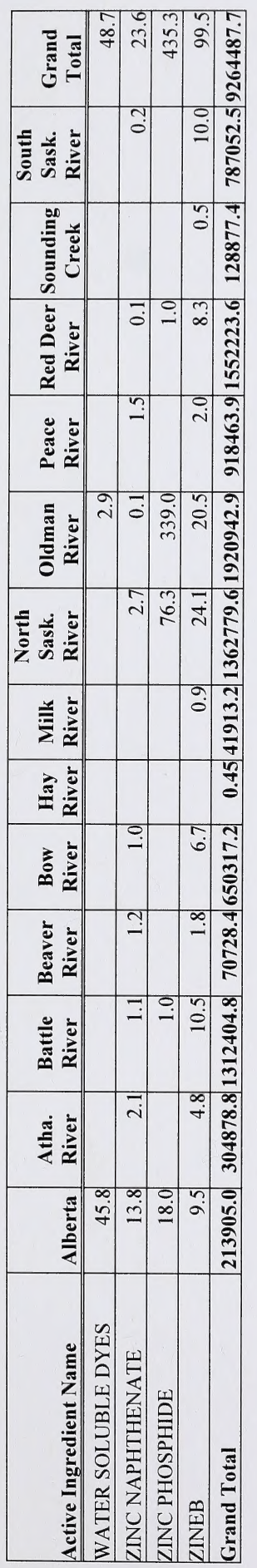




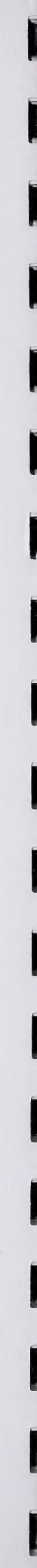



LIBRARY AND ARCHIVES CANADA

Bibliotheque et Archives Canada

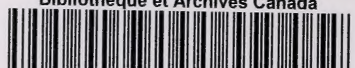

33286539327912 